\title{
AGRICULTURAL POLICY
}

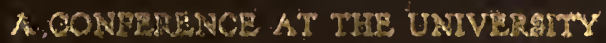
OH WIHAOIS, JANUARY 26-27, 2922

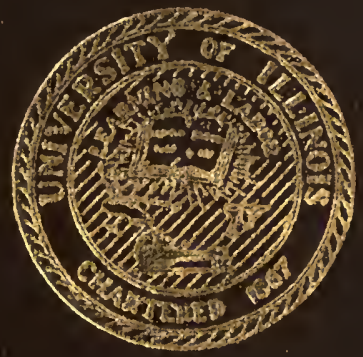




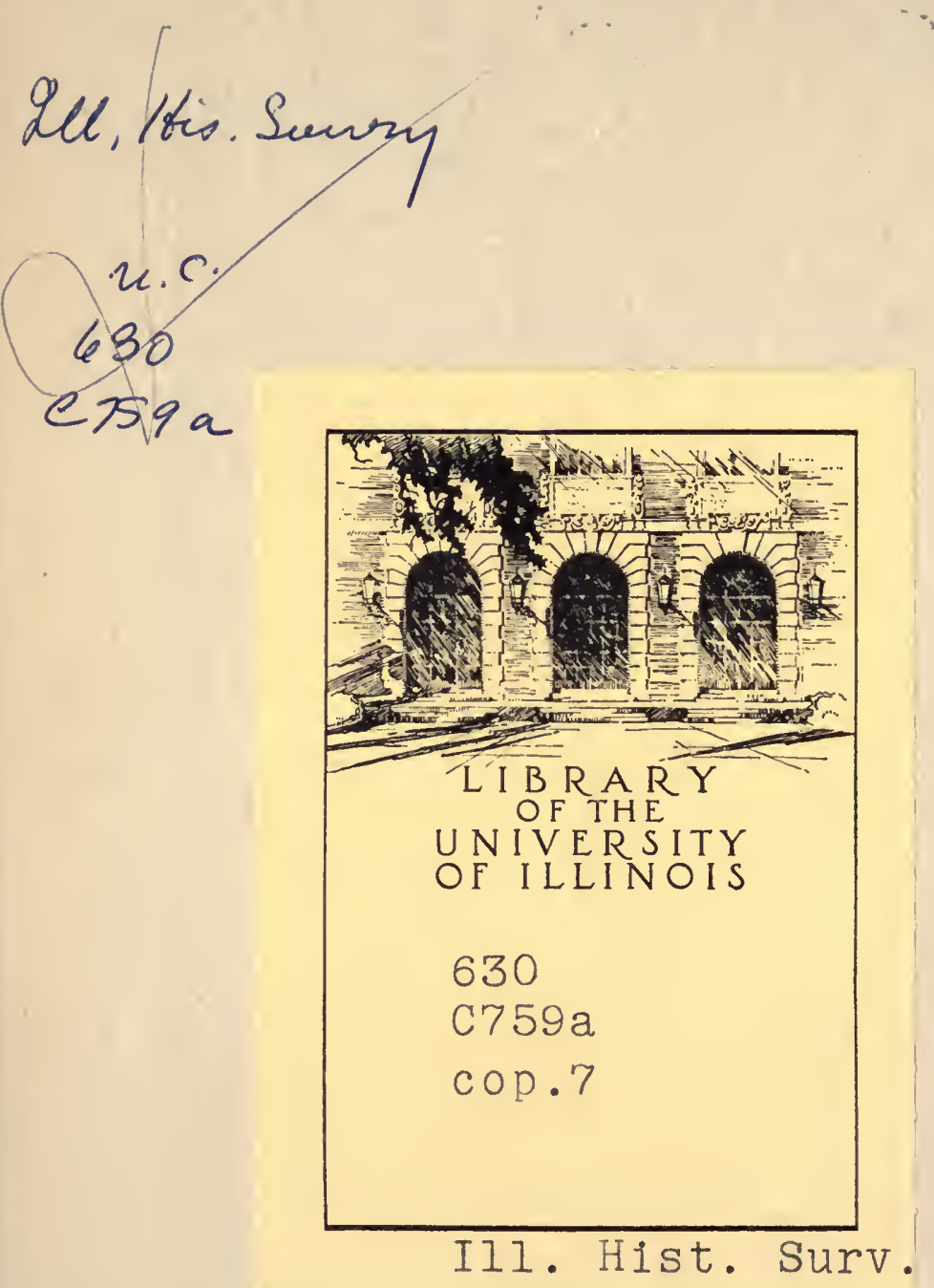


Hhooke b. Veno 






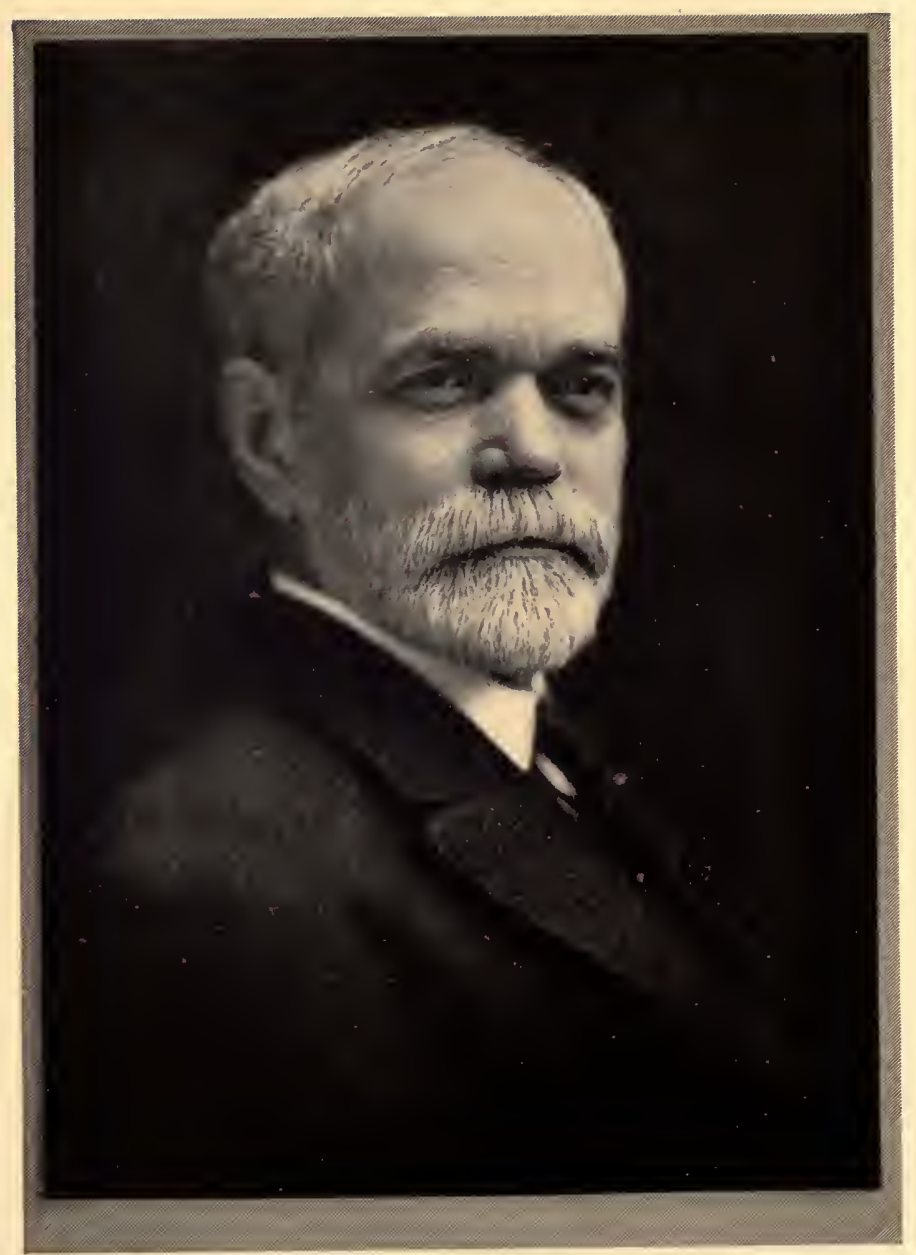

Eugene Davenport 


\section{PAPERS \\ PRESENTED AT A CONFERENCE ON \\ ILLINOIS AGRICULTURAL POLICY}

January 26 and 27

1922

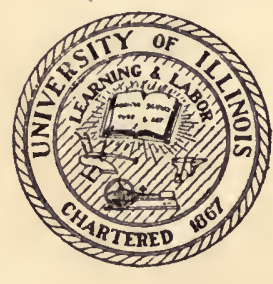

PUBLISHED BY THE UNIVERSITY OF ILLINOIS URBANA 


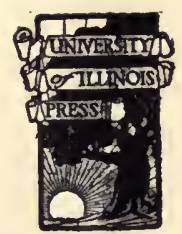




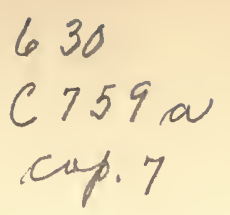

CONTENTS

PAGE

INTRODUCTORY STATEMENT $\ldots \ldots \ldots \ldots \ldots \ldots .7$

I. A QUARTER-CENTURY OF AGRICULTURAL PROGRESS IN ILLINOIS: A REVIEW OF ACCOMPLISHMENTS

A System of Permanent Agriculture

Ralph Allen ................................. 11

Developments in the Dairy Industry

N. W. Hepburn............................ 16

Developments in Horticulture

J. C. Blair................................. 27

The Work of the Agricultural Experiment Station

L. Н. Ммітн.............................. 37

The Work of the College of Agriculture

Fred H. RANKIN............................ 46

II. NEWER PHASES OF AGRICULTURAL PROGRESS

Newer Problems in Soil Treatment

FRANK I. MANN.............................. 56

Business Aspects of Farming

Charles A. Ewing............................. 61

The Farm Bureau

E. T. RobBins............................... 71

The Illinois Agricultural Association

D. O. Тномpson.............................. 79

An International Crop Reporting Service

H. J. SCONCE.............................. 82

Financing Farming

J. D. Phillips. 


\section{AGRICULTURE IN I'TS RELATION TO O'THER INTERESTS}

The Business of Farming in Some of Its Larger Aspects

Thomas Nixon Caryer........................ 91

The University and the Farm

David KinLEY ............................... 101

\section{NEX'T STEPS IN AGRICULTURAL DEVELOP- MEN'T IN ILLINOIS: A PROGRAM FOR A BETTER BALANCED AGRICULTURE}

The Introduction of New Crops

C. L. Meharry

Farm Forestry in Illinois

А. N. Аввотт............................. 120

Can Illinois Come Back as a Stock Breeding Ground?

W. S. Corsa............................. 122

The Outlook for Live Stock in Illinois Agriculture

H. W. MUMFORD 128

Roadside Improvement

W. N. Rudp............................. 136

The Country Home

J. V. Stevenson........................... 142 
V. THE PLACE OF THE AGRICULTURAL COLLEGE AND EXPERIMEN'T STATION IN AN ILLINOIS PROGRAM FOR AGRICULTURAL DEVELOPMEN'T

Physiological Bases of Crop Production

W. L. BurLison

Economic Phases of Farming

W. F. HANDSCHIN

The Agricultural Extension Service

M. L. MosHer................................ 170

Some Next Steps in the Work of the Agricultural College and Experiment Station

Eugene Davenport 



\section{INTRODUCTORY STATEMENT}

$\prod$ HE retirement of Dr. Eugerie Davenport from the deanship of year will close an era in the agricultural educational history in Illinois. His withdrawal comes at a time of depression in the farming interests of the state. For both these reasons it seemed to me well to call a conference of people interested in agriculture, to review the agricultural development of the state from the educational, scientific, and practical viewpoints for the twenty-five years through which Dean Davenport has served, and to try to frame, if possible, the main outlines of a general policy of agricultural development for the state in the next quarter of a century.

Accordingly, a call for such a conference was issued on January 4,1922 , as follows:

\section{A CALL FOR A CONFERENCE ON ILLINOIS ÄGRICULTURAL POLICY}

The present wide depression in agriculture has again called the attention of the country sharply to the fundamental position of agriculture in the economic life of the people. The condition of the farmer through the past twelve months has impressed upon people's minds more firmly than ever the idea that the prosperity of all of us rests primarily upon the prosperity of those of us who are engaged in agriculture.

The present condition of depression in agriculture, whatever the immediate causes of that depression, enforces upon our attention two important problems. One is the early relief from the prevalent economic pressure under which the farmers are living. The other is the factors at work to influence and give direction and character to American agriculture in the next quarter of a century. While the present depression is, speaking in a general way, a result of the war, there are reasons for thinking that it is part of a readjustment, not only of temporary conditions, but of conditions which in character are more permanent. In other words, American agriculture probably reached a point within the past decade at which it was to assume a different character from what it had in the past generation. There is ground for the belief that much of our cultivated land under prevalent prac- 
tises and existing knowledge, has reached the point of diminishing returns. It has become a serious question whether large-scale agronomic farming, as hitherto practised, is likely to be as successful in the future on certain acres of our land as it has been in the past fifty years. Reduction of fertility, increase of population, changes in economic relations of agricultural groups and classes, as well as other influences, are factors in deciding on this point. Our beef-raising industry has changed geographically and economically as well as in many of its practises. Areas that a few years ago were largely devoted to successful cattle breeding are no longer suitable for that purpose. Old farming practises whether in large-scale or small-scale agriculture, are changing and will undoubtedly change more. We must find answers to such questions as these:

How can farming be made to pay, especially in those parts of the country where the value of farm land has largely risen?

What attitude shall the community take towards the increase in tenant farming?

Can anything be done to restore cattle production on a large scale in states like Illinois, which have lost their preëminence in that industry?

What effect is the growth of cities having on the size and character of nearby farms?

How can we insure the permanent retention of the fertility of the soil?

Is there any system which might be adopted whereby the adaptation of different crops to different soils may be more accurately determined, and the use of proper crops on soils be insured?

What can be done to preserve the country home?

Aside from these questions affecting permanent policy, we should find a method soon of relieving the present pressure on the farmer. Agricultural finance is one of the pressing problems of the day.

While the topics referred to in the preceding paragraph, and many others of like character that will suggest themselves to the reader may be asked with reference to the country as a whole, it is peculiarly our duty in Illinois to ask them with reference to Illinois agriculture. It is fitting, too, that the question should be discussed at the seat of the College of Agriculture and the State Experiment Station which the people have established to aid them in the solution of these and similar live problems. For that reason, after conference 
with my colleagues at the University and others interested, I am calling a conference of farmers, scientists, and educators in agriculture to be held at the University of Illinois College of Agriculture on Thursday and Friday, January 26 and 27, 1922, to consider, as far as time will permit, the general subject of the future of agriculture in Illinois in the next twenty-five years. What should be the agricultural policy of Illinois? Can we decide in advance on suitable methods of tillage for the different soils of the state? Can we restore our preëminence in beef cattle production? What can we do, to make conditions of living in the country sufficiently attractive to maintain the balance of desire for country and city life so far as that desire is determined by general living conditions? What are the relations of farming to industry and trade?

These and other questions will be discussed.

In the name of the University, and particularly of the College of Agriculture and the Agricultural Experiment Station, I take pleasure in inviting all citizens of the state who are interested in the matter, to be present at this conference and to take part in its discussions.

At the conclusion of the Conference a committee was appointed to consider the propositions advanced and discussed and to report at as early a date as compatible with thoro consideration, whatever recommendations or proposals appear to the committee to be helpful in determining the general direction of our agricultural development. The committee appointed consists of:

Charles A. Ewing, Decatur (Chairman)

FrANK I. MANN, Gilman

EUGENE D. FUNK, Shirley

W. S. CoRsa, White IIall

GEORgE A. Fox, Sycamore

W. S. Perrine, Centralia

W. N. Rudp, Blue Island
A. N. Аввотт, Morrison

Jos. R. Fulkerson, Jerseyville

H. T. RAINEY, Carrollton

J. V. STEVENSON, Streator

HARVEY J. SCONCE, Sidell

Herbert W. MUMFord, Urbana

WALTER F. HANDSCHIN, Urbana

The papers presented at the Conference are printed in this pamphlet. The committee's report will be printed separately when it is received.

David KINLEY

President 



\section{A SYSTEM OF PERMANENT AGRICULTURE}

\section{Ralph Allen, Delavan}

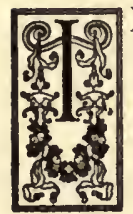

N ORDER to understand better the system of soil fertility, as advocated in Illinois, one should be somewhat familiar with the motives which inspired Dr. Cyril G. Hopkins, its originator and promulgator. The ultimate goal toward which Dr. Hopkins labored was the solution of the problem of an unlimited food supply for man, even when his numbers were constantly increasing. He realized that the decadence of empires and of civilization was primarily due to underfed, underdeveloped peoples, caused by the depletion of the soil's power to produce sufficient food; and that the powerful people of the earth were those only who lived upon the new and unexhausted lands.

The progressive movement of civilized man has been westwardnew lands have been occupied and exhausted until the circle of exploitation of the earth is about completed. Dr. Hopkins realized that the decadence of man as a civilized race must therefore follow, unless a system of soil renewal could be discovered whereby the effect of man's occupancy of the land could be reversed from soil destroying to soil building. In this process he knew that the farmer must be the active agent; therefore the farmer must receive the first consideration. The farmer must prosper. He must realize a compensation for his labor comparable with that of other industries. His business should pay sufficiently to bring back quickly the money paid out in the process of renewing the soil. In other words, agriculture to exist must be profitable. Dr. Hopkins' object, therefore, was to bring about a permanent human food supply, at the same time looking out for the well-being and profit of the farmer.

\section{A System That Is Profitable}

Before the time of Dr. Hopkins, soil investigators had learned many things relating to the use of chemical elements in producing the growth of plants. But to secure the benefits of this knowledge in such a wholesale way that all farmers could practise the system and keep the cost of production below the money value of the increase in the crop, it was necessary to discard every expenditure possible. Dr. Hopkins realized that the success of a system of agriculture which would produce an abundance of food for all would depend upon freedom from competition between farmers for their supply of the 
elements of fertility. He therefore incorporated into the Illinois System of Permanent Agriculture the use of such natural forces and resources as are available, free and equally to all farmers alike, and which cost nothing; instead of resorting to the costly processes of fertilizer manufacture in order to accomplish this purpose. This principle is one of the distinctive features of the Illinois system of permanent agriculture. For example, in pursuance of this theory, he used bacteria to get the soil nitrogen, discarding the commercially prepared, highly expensive forms of nitrogen. He used soil acids of decomposition to render soluble the insoluble phosphates in place of those commercially and more expensively prepared. The mineral elements needed for the soil he secured as nearly as possible in their most natural forms; as, for example, raw rock phosphate, prepared only by being finely ground; and lime, used in the form of coarsely ground limestone.

\section{Fertility Is Maintained and Increased}

He recognized the fact that every crop grown takes something out of the soil, and no matter how great the resources of fertility may be, unless that which is taken out is returned, the soil will eventually be exhausted. On the other hand, he saw that with a system of soil treatment which would provide for the return to the soil of those elements which are removed, the fertility of soil so treated could be maintained indefinitely; and in case more was returned to the soil than was taken from it, such soil would steadily increase in productiveness.

Still further, he realized that lands naturally barren, or lands long since exhausted by farming and abandoned by man, could be made once more productive by the same process. A very distinctive feature of the Illinois system of permanent soil fertility is that it builds up the soil to a permanently higher state of fertility. We may take, by way of example, the practise of applying to the brown silt loam type of soil, which contains twelve hundred pounds of phosphorus per acre in the stratum turned by the plow, one ton per acre of fourteen per cent raw rock phosphate during each five-year rotation. After deducting the loss of phosphorus occasioned by taking off two sixtybushel crops of corn, a sixty-bushel crop of oats, a thirty-bushel crop of wheat, and a crop of two tons of clover, there would be accumulated in the soil at the end of four rotations, or twenty years, a quantity of unused phosphorus sufficient to build up the phosphorus content of the soil to well above the standard for fertile soils, which is two thousand pounds per acre. This is in contradistinction to other systems of fer- 
tilizing the soil which have in view only the effect upon the immediate crop and which commonly apply less phosphorus per acre than the crops remove during each rotation; with the result that at the end of the twenty-year period, there is a depletion instead of an increase in the total phosphorus content of the soil.

\section{Differences in Solls Recognized}

Another characteristic feature of the Illinois system of permanent soil fertility is that it recognizes the differences in soils. It takes into consideration the fact that they differ in physical character and in chemical composition, and that their treatment must vary according to these differences. In the beginning of Dr. Hopkins' work, therefore, the necessity for a thoro knowledge of all the soils of the state was apparent, and a survey of the soil types of the state was commenced and is still going on. Among other things, this survey aims to determine what the character of these types is, both chemical and physical; what constitutes the differences between one type and another; where the different kinds of soils are to be found, together with their exact location and boundaries.

Realizing still further the necesssity of recognizing the differences in soils, experimental fields were established and are still maintained by the Experiment Station on varying types of soils, in order to test out, by means of growing crops, the different systems of soil treatment, and to learn how the soils respond in crop production to applications of different elements of plant food. These fields are, by long-time leases or by deed, devoted permanently to these soil experiments; so that with the lapse of time, the effect of the system on the permanency of the improvement in the soil will become known.

Two systems of farming have been in operation on many of the experiment fields. One is called the live-stock system and the other, the grain system. The object of maintaining these two systems is not to determine whether one is better than the other, but rather to determine ways to maintain the fertility of the soil under either system. The grain system is applicable to the great grain-growing areas, where almost all the grain is sold from the farm, none being fed to live stock and no manure made. It consists in substituting for manure the use of leguminous catch crops, all crop residues being plowed under. The live-stock system includes the use of manure in such amounts as can be made from the crops grown. Under either system, the crop rotation and the supply of minerals are the same, the humus and nitrogen of the soil are maintained in about the same amounts, and the crop yields obtained are also the same. 


\section{Based on Extensive Investigations}

The extensive organization for soil investigations put into operation by the Illinois Experiment Station under the direction of Dr. Hopkins is the most extensive of any that has ever been operated and should be continued. The soil survey should be completed as rapidly as possible while there is yet time to complete it under the present direction, not only in order to carry out the present standard of detail and accuracy but to give it that uniformity of classification which can best be attained in work of this kind when it is done by the same individual. I would recommend that the soil experiment fields be fully continued, for the longer they are operated, the greater is the worth of the results. New and unforeseen results and problems are appearing in the long-time operated fields, which did not show earlier. These fields, which are also used as demonstration fields to show the effects of soil treatment on crop production to farmers, are visited annually by many farmers and landowners. A community interest in them has already developed, and I believe the people would resent anything which endangered their continuance.

\section{A Permanent and Steady Food Supply}

To sum it all up: The thing which distinguishes the Illinois System of Permanent Agriculture is its object; which is to bring about a permanent and steadily increasing human food supply, limited more by human labor than by earth's resources. The one condition is that the system must be profitable as a business, for if agriculture cannot prosper it cannot continue. The system is distinctive in that it may be practised equally by all farmers, with little competition between one farmer and another. As far as possible, it displaces costly human effort in the form of commercial fertilizers by using instead the freeto-all natural forces and resources. It solves the problem of treatment specifically for each and every type of soil. It provides in a practical way for the return to the soil of each of the elements of plant food taken from it by cropping or by leaching, and in such a generous way that more is actually given back than is taken out, so that the final replenishment of the earth's soils is assured. In short, the system builds up the soil. It brings back again to profitable productiveness lands long since barren and abandoned; and it shows the way by which all lands that can be cultivated may, as time goes on, become capable of producing more and more food. 


\section{Doctor Hopkins' Life Work}

The solution of the problem of the human food supply is the culmination of Dr. Hopkins' life work. It is a thing complete in itself. I liken it to the discovery by Columbus of a new continent: the discovery was complete in the first voyage, others could develop his findings. So Dr. Hopkins' great life work was complete when he devised the system of agriculture which showed the way to change the habit of man from soil ruin to soil building; but the development of this great work, like that of the discovery by Columbus, will take centuries.

It is almost impossible for me to think of the Illinois system of permanent agriculture without continually having in mind the personality of Dr. Cyril G. Hopkins, its author; and I have referred to him in this paper frequently. There were others who were intimately associated with him and who gave essential help in the development of this soil system. Two of these were with him so long and were so essential to the success of his plans that I feel I should mention them. In writing this, I speak from personal knowledge of the relationship existing between Dr. Hopkins and them. The first, Professor J. G. Mosier, has charge of the soil survey; and it was his skill in soil classification and accuracy of work that achieved the reliability of the survey, without which the survey would have had little value. The second, Dr. Eugene Davenport, took an active and essential part in the development of the Illinois system of permanent agriculture; and his influence pervaded every feature of Dr. Hopkins' work. Primarily a soil student, thoroly informed in the soil literature of the day, having already commenced the system of soil investigations in Illinois by laying out a complete system of soil experiments at the University Experiment Station and in the southern part of the state, Dr. Davenport was eminently prepared to cooperate through the whole course of Dr. Hopkins' investigations. This relationship amounted really to interdependence and, it seems to me, was essential to the formation of the Illinois system of permanent agriculture.

Dr. Hopkins' discovery stands out as a distinct endeavor. It was new, unheard of, unthought of. He was the first to call the world's attention to the thought of safeguarding and making a plan for the permanent food supply through the conservation of the soil. 


\section{DEVELOPMENTS IN THE DAIRY INDUSTRY}

\section{N. W. Hepburn, Peoria}

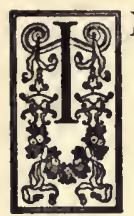

N THE field of dairy husbandry we find a natural division occurring between production, on the one hand, and the manufacture and sale of dairy products, on the other. The two are so interdependent, however, that any review of the development of dairying would not be complete without considering both phases of the industry. It is almost impossible to point out the progress, either in the production or the manufacture and traffic in dairy products during the past twentyfive years, without first going back into the period just preceding the time in question.

It was only natural that Illinois should, in the early days, develop as a grazing state. Her almost boundless prairies, rich in native grasses, furnished ideal forage for cattle and sheep. With a scanty population, there was no particular demand for milk or butter or cheese, except to satisfy the individual needs of the family. With the increased production of grains, particularly corn, it was only another step to feed these grains to live stock to fatten them for market. And thus was built up the system of feeding and fattening animals, many of which were raised on the ranches farther west. It was not until 1855-1860, with the opening of a market for whole milk in Chicago, that there was any great stimulus toward the production of dairy products in Illinois. Since that time, the development has been rapid. Broadly speaking, we can classify producers under two heads. The first group includes those farmers who derive their major source of income from the sale of dairy products; the product which they produce is for the most part whole milk, and they are located generally in close groups around the larger cities. Over against this group is one which is much more widely distributed, and which derives its revenue principally from the sale of cream; in this group dairying constitutes merely an important side line. The development in these two groups has been simultaneous, tho the factors causing the growth have been somewhat different.

\section{Factors Responsible for the Development of Production}

In a general way we may say that four factors have been largely responsible for the development of production. They are: first, the introduction and utilization of the silo; second, the centrifugal cream 
separator; third, the discovery of a simple test for fat in milk; and fourth, better and more rapid methods of transportation, together with the development of refrigeration.

It is interesting to know that the first silo in Illinois, and indeed in the United States, so far as we have records to show, was built by Sidney Hatch, of Spring Grove, in 1873. The real development of the silo, however, has occurred during the last quarter of a century. We have now come to regard the silo and the use of silage as sc important in economical milk production that few dairymen indeed would attempt to produce milk without them. DeLaval, when he applied the principle of centrifugal force to the separation of fat from the other constituents of milk, was truly a benefactor to the small farmer who was then producing butter as a side line. Until the discovery of the "Babcock test" for fat in milk, there never had been a satisfactory basis for establishing the selling price of that product. With the introduction and general use of this simple test it became possible to differentiate between milk carrying different percentages of fat. This gave a measure of value which had hitherto been impossible. It tended to stabilize the market, and gave a confidence to the producer which he had not felt before. Furthermore, it gave him an opportunity to measure the production of his cows and to get production over to more nearly a business basis. The dairyman was keen to see the advantage of knowing the production of each cow in his herd. This in turn led to the development of cow-testing associations; which have shown a marked growth during the last ten or a dozen years. In fact, from one cow-testing association in 1910 which tested about three hundred cows, we have gone to twenty-six associations in 1922 , which have tested nearly eleven thousand cows. Undoubtedly the fat test for milk has been a big factor in the development of production.

Better and more rapid methods of transportation, together with the use of refrigerator cars, have materially widened the zone of whole-milk production. In fact it is now possible to deliver fluid milk on the central market over a distance of three hundred miles in as good condition as it would have been delivered in one-tenth that distance forty years ago. Indeed it is reported that during a recent milk strike in the St. Louis region, milk was shipped in considerable quantity from the state of Michigan and arrived in good condition. The same development in transportation has aided the cream producer, and has made possible the establishment of the large centralizers for the manufacture of this cream into butter. 
Finally, it would not be possible to discuss the question of production during the past twenty-five years without making mention of the mechanical milker. The last quarter of a century has seen the development of the milking machine from its merest beginning to its present extended use. There may be some question as to how much machine milking has stimulated production, and there may be some question now as to its ultimate success, but certain it is that it has been an important factor in production and should receive a great deal of attention in the years to come.

\section{Dairy Products}

In Illinois the manufacture and traffic in dairy products is now less than seventy-five years old. Prior to 1850 little or no attention was given to any form of dairying. Butter-making at that time was considered one of the household duties, carried on principally to supply the family needs for butter, the excess being taken to the store for what was termed in those days "store pay." This resulted in the accumulation of miscellaneous lots of butter of inferior quality, which was packed in boxes or barrels and sold in the East as Western butter. Thus, in the early days the Middle West established a reputation for inferior dairy products, which it took years to overcome.

Naturally, as soon as more cows were kept than were needed to supply home demands, one of the first forms of commercializing the industry was that of selling whole milk. This branch of the industry may be said to have begun in 1852, when P. H. Smith, of Elgin, took one eight-gallon can of milk to the Northwestern station and shipped it to the old City Hotel in Chicago. From that time on until now the industry has grown until we could not measure the calamity that would result if the supply of thousands of such cans were shut off from the city of Chicago for a single day.

In 1877 the Chicago Journal published the following article; which not only shows the development of the city milk business but also gives the public view of the business at that time:

The item of milk for daily consumption in a city like Chicago is something enormous. This supply must come from the rural districts, and within a limited range, as it it not found desirable to transport the fluid too great a distance. Coming pure from the farms, it might become butter if indulged with too long a ride. The great bulk of the supply for Chicago comes from Cook, DuPage, Kane and McHenry counties, the famous Fox River valley furnishing three-fourths. Throughout these counties are hundreds of splendid 
farms entirely devoted to dairying, and the milk is either shipped to Chicago per rail or sold to the numerous factories where it is manufactured into butter and cheese.

About the year 1860 the number of dairy cows kept had increased to such an extent that more milk was produced than could be handled as such, and with this oversupply came the temporary rise of the cheese industry in Illinois. The cooperative system was soon inaugurated, and instead of the manufacturer looking for a purchaser, the purchaser came to the manufacturer. The Elgin Board of Trade was established in 1872, where purchaser and producer could meet on middle ground.

The rivalry between the factories as to the price they would pay for milk led to the practise of taking off a little cream. Another dealer, in order to meet this kind of competition, would dip off a little more; and so on. They added the buttermilk, cooked very slightly, salted but little, and hurried up the curing as fast as possible. The dealers soon began to complain and therre was no longer the great demand for Illinois cheese. The reputation of Illinois cheese was gone. In 1865 Illinois had seventeen cheese factories; this number had increased to forty-six in 1870 . By 1890 many factories were engaged in the manufacture of filled cheese, which increased rapidly until about 1896, when a law was passed prohibiting filled cheese. Within a few months Illinois dropped almost to the bottom as a cheese producing state; and today there are only about fifteen factories making cheese.

Following closely on the fall of the cheese industry we read of the development of the creamery industry; which, in the main, is familiar to most of you. About 1870 the matter of establishing a creamery in Elgin began to be discussed, and it was Dr. Joseph Tefft, of Elgin, who was instrumental in establishing the first butter factory west of the Lakes. It was here, in a factory superintended by J. $\mathrm{H}$. Wanzer, with the help of some of the stockholders' wives, that the first creamery butter west of the Lakes was made. The second season this factory made 80,000 pounds of butter. For a time many factories made both butter and cheese; and even now we find, scattered over the state, creameries which were originally designed for the dual purpose of manufacturing both cheese and butter. The second creamery was probably that of I. A. Bois, of Marengo. Thus the industry developed until in 1883 there were about four hundred factories. In 1885 one of the first creameries opened in southern Illinois at Sparta. From this time on, the industry grew rapidly until 1898, at which 
time there were over five hundred factories in Illinois. Many of these so-called cooperative creameries were established through promotive schemes directed largely by creamery supply houses. Ninety per cent of these plants were financial failures.

\section{Development in the Field of Dairy Products During the Past Twenty-five Years}

With this background in mind, the developments in the field of dairy products during the past twenty-five years constitute a history of marvelous growth and achievement, made possible through the combined effort of business acumen and scientific achievement. Today, under the list of dairy products we include: whole milk for drinking purposes, condensed milk, dry milk, ice cream, butter and cheese, with the respective accessory products or by-products, under which may be included perishable soft cheese, dry and condensed buttermilk, milk drinks, whey, casein, and casein products. In the period just described, these products were considered as isolated units of the industry, having little or nothing in common so far as their manufacture and distribution was concerned. Today we think of them and deal with them in terms of their respective relationship, determined largely by their relative perishability. For instance, if we take a large consuming center like Chicago and make a study of the dairy activity surrounding it, we find first a zone producing milk for city consumption. Just outside this zone and somewhat overlapping it, we find a zone in which the milk produced, together with a portion of the surplus milk from the inner zone, goes into condensed milk, powdered milk, and ice cream. Farther out, with poorer transportation facilities, yet situated in the region of good production, we find the cheese factory; and still farther out, in the non-dairy regions, we find the cream produced for butter-making purposes. During the period under discussion, these zones have been gradually pushed out to fill the requirements of a milk supply for our large cities, one effect of which has been to crowd the cheese industry out of Illinois territory.

\section{City MilK}

The providing of our consuming centers with milk for direct consumption has grown, during the past twenty-five years, to be a tremendous industry. From the small beginning described earlier in this paper as P. H. Smith's efforts to furnish milk to the growing city of Chicago, the industry has grown to a point where the Nation's milk 
bills last year totaled about one billion dollars. During the period under discussion this growth represents an effort to keep pace with the growing population in our consuming centers, rather than any marked increase in our per capita consumption.

Accompanying this enormous growth in the volume of business, there has been a corresponding improvement in the handling of the product. We have passed from the stage of so-called "dip milk" to a highly specialized system, extending from the farm to the consumer, under which a thoroly safe, pasteurized product is delivered to the consumer's door in an original sterilized container. Thus the city milk business has passed out of the hands of the street peddler into the hands of large organizations who may justly be called "specialists" in this branch of the dairy industry. These advances have been made possible largely through the joint effort and cooperation of the producer, the business man, the scientist, boards of health, and machinery men. Over twenty years ago the scientist pointed out the relation between public health problems and a city's milk supply, and today our whole program of milk distribution is built around the one idea that the consumer must have an adequate supply of healthful milk at a reasonable price. The real milk man has been shaping his business with this one idea in mind. His efforts are represented: First, by consistent field work in the country looking toward an improved supply. Here he has been assisted materially by the scientist, who has furnished not only the standards but also the means for measuring the quality, so far as this can be done. Second, nothing that modern skill or science could suggest has been left undone in the plant toward the turning out of the very highest quality product. In fact, there is no food today surrounded by so many precautions as is our modern milk supply. Probably no greater single development for the handling of milk has been accomplished than the invention of our modern equipment for perfect pasteurization,-a process almost universally recognized as a necessity for a safe milk supply. Here we might justly add that the machinery firms have spent millions of dollars in the development of machines, all of which have been periodically junked and replaced by something more efficient; until the operation of putting the vast quantity of milk through a city plant today, from the receiving to the delivery door, represents almost none of what might be called "hand labor." Another branch of this same industry, growing largely under the direction of the scientist, is the certified milk industry, and while I do not wish to dwell on this phase of the subject, it is worthy of comment that the first certified milk of which we have 
any record was that which $H$. B. Gurler, one of the pioneers in dairying, shipped from this state to the Paris Exposition in 1900.

Like all other developments, the supplying of a city with the proper kind of milk has met with its share of opposition, from uninformed doctors, civic organizations, health officials, and politicians; but out of it all we are able to define quite clearly the principles upon which a sound milk supply should be based.

The serviceability of these improvements may be summed up briefly by saying that milk is today one of the cheapest and one of the most accessible of foods for the city dweller, in spite of its perishable character; and an epidemic traceable to milk is almost unheard of.

\section{The Ice Cream Industry}

The ice cream industry has made its growth in Illinois as well as in the United States practically within the last fifteen years, during which time it has passed from the one-horse tub freezer stage to an industry as highly specialized as the milk industry itself. Earlier in this paper it was suggested that for the successful operation of plants making dairy products, there is a necessary interdependence, brought about by the fact that the milk supply is irregular, yielding a tremendous flush of milk during the spring months, with a corresponding shortage in the winter months. The development of the ice cream business, and the condensed and dry-milk industry has done much toward equalizing this situation; thereby bringing a more uniform price to the producers and enabling the manufacturer to handle the product of the dairy during the surplus season with less loss than was occasioned during the days when all surplus was skimmed for butter-making and the skim milk returned to the farm, if possible, or run into the sewer. Inventions which have done much toward equalization along this line are the emulser, the homogonizer and the viscolizer. These machines are constructed for the purpose of emulsifying the fat of butter with fresh skim milk or dissolved dry milk to again form cream. This process permits the temporary storing of the valuable constituents of milk in a less bulky form until such time as they are needed.

Within the last five years the ice cream industry has passed from the ranks of a confection to the ranks of a food product. This important transition has come about largely through the combined efforts of the manufacturer, the scientist, and the law-maker; which have resulted in a standardized wholesome product, well deserving of the place which it now holds in the eyes of the consumer. 


\section{Condensed and Powdered Milk}

The condensed milk industry in this state dates back to 1865 . Long ago the pioneer dairyman recognized the necessity for some means of converting a portion of our spring surplus of milk into some product more valuable than either butter or cheese. The answer to this demand was found in the condensing process. This branch of the industry, like the others described, has reached enormous proportions. At the present time there are approximately forty plants operating in Illinois. This industry received a marked stimulus during the war, during which time there was an unusual demand for condensed milk. Not only did the condensing plants increase in numbers during that time, but those already in existence more than doubled their output. The close of the war found both this country and Europe heavily overstocked with evaporated milk, - so much so, in fact, that during the past two years many plants have been entirely closed, waiting for the time when their old stocks would be cleared away.

Another departure which comes well within the period of progress under discussion is the development of the powdered-milk industry. This is a process by which either whole milk or skim milk is reduced to a powdered form containing only the solids of milk. The resulting product contains all the valuable constituents of milk in a volume which measures only eight per cent of the original milk. Dry milk is readily put back into solution and used for drinking purposes, in baking or in ice cream. This industry is still in its infancy and opens a fruitful field for the investigative mind. It should also be mentioned in this connection that this same process has been applied to buttermilk, resulting in the conservation of millions of gallons of this product which were formerly wasted.

\section{Butter Manufacture}

The manufacture of butter is not usually thought of as one of the large dairy-product industries. However, if we take the United States as a whole, the value of the butter approximately equals the combined value of all other dairy products. When we study the developments in the butter industry in our own state during the past quarter of a century, we find more significant changes than in any other branch of the dairy industry. The two inventions which have exerted a major influence in bringing about these changes have been the Babcock test and the farm separator. 
Twenty-five years ago the raw material for butter-making was delivered by the farmer to the creamery door in the form of whole milk, which was skimmed, and the cream churned into butter, for which payment was made monthly or semi-monthly. The by-product, skim milk, was returned to the farm for pig feed. The introduction of the farm separator has revolutionized this branch of the industry. The producer was quick to see the economy of a less bulky product, in the form of cream, as well as of less frequent deliveries. This economy, combined with the fact that the souring of cream does not necessarily deteriorate its quality for butter-making purposes, enabled the cream to be shipped long distances to the concern which would give the best satisfaction. The use of the separator has thus resulted in a concentration of the creamery business into a fewer number of large, modern plants, where economy of every kind is resorted to, the results of which are reflected in the producer's cream check. While the amount of butter manufactured in Illinois creameries is more than double that of twenty years ago, the number of plants is less than one-sixth as great, and sixty per cent of the butter is made in less than thirty plants.

Outside the changes which have taken place in the actual making of butter, two very important developments in the productive side of the business are worthy of mention. First, in respect to the relation between the amount of farm-made butter and creamery butter: Twenty-five years ago, the amount of farm-made butter exceeded that made in the creamery by three times; in 1910 the Census reported 46,000 pounds produced on farms and 24,000 pounds in factories; and at the present time this ratio is practically reversed. This is another way of saying that by the introduction of the hand separator this branch of dairying has been carried to the remote parts of the state; and it is almost a uniform practise, even on our corn-belt farms, to keep a few cows, the product of which is shipped in the form of cream to some centralizing creamery to be made into butter. Thus the creamery industry has converted a comparatively low-priced product, "farm butter," into a high-priced product, creamery butter, the benefit of which largely goes to the producer. As an interesting incident in this connection, it may here be noted that the withdrawal of this large amount of farm butter from the market has virtually closed the plants which formerly made renovated butter.

On the inside, or in the manufacturing plant, the development has been commensurate with the development in the field. Great institutions capable of making and marketing millions of pounds of 
butter at a minimum expense have grown up. These plants have been departmentalized, in order to render a maximum service to producer and to consumer alike. This means that in the creamery business, not only methods of procuring the raw material, methods of handling and manufacturing, and great improvements in machinery have been developed, but also that the business end of this great enterprise has grown from a haphazard practise to a highly specialized system equal to any other industry of today.

As in the milk industry, science has contributed its share to modern creamery practise. Many of our large plants today have well equipped laboratories with a scientific staff whose duty it is to standardize and control plant methods, and conduct research into problems bearing on the various phases of the industry. Some of the important developments growing out of such studies are: methods for determining acidity of cream; control of acidity of cream; methods of determining moisture and salt and fat content, and means of controlling them in the finished product; and rapid bacteriological tests indicating the efficiency of sanitary measures and pasteurization. It may also be of interest to state that one of our large machinery organizations characterizes itself as an organization of "dairy engineers," and that much of their effort has been spent in making short cuts of chemical and bacteriological methods which would reduce these operations to a basis of every-day plant practise.

All of this does not mean that our creamery problems are all solved; on the contrary, this new development comes laden with problems of both a business and a scientific character.

\section{Cold Storage Facilities}

Parallel with the development within the industry has been the development of cold-storage facilities, a system little understood by the consuming public. Often the storage house is described as a receptacle for hoarding food and its operator as a parasite living off the public; but when we realize that one-half of the volume of butter produced is produced in three to four months, we cannot fail to recognize that the storing of a perishable product like butter is quite as desirable as the canning of peaches in the time of plenty for the winter supply. In the absence of cold storage, a part of our supply in the spring would be almost valueless, and in winter our prices would be prohibitive. So the storage house, properly conducted, performs the double function of storing and financing our butter surplus. 


\section{Organizations}

In the field under discussion we cannot fail to recognize certain agencies outside of the manufacturing plants themselves, which have played their part in our progress. I refer to such organizations as the National Dairy Council, which, recognizing the fact that our dairy products must necessarily be marketed at home, and realizing that our production is already up to our consumption, has set out, during the past ten years, on well-planned educational campaigns, looking toward the increase in consumption of all dairy products. The American Association of Creamery Butter Manufacturers, with Professor McKay as its secretary, has functioned for the whole creamery industry for ten years as a clearing house for the many problems which have confronted the centralized creamery business. The Association of Illinois Butter Manufacturers, which was formed about a dozen years ago, has served its purpose in eliminating numerous trade evils which seem necessarily to exist in a new-formed industry. The Illinois Ice Cream Makers Association has performed a similar service for the ice cream industry.

As has already been suggested at many points in this paper, much of the development indicated as having taken place in the last quarter of a century has been made possible through the various activities of the Agricultural College. This assistance has taken the form of new scientific discoveries, the adaptation of chemical and bacteriological methods to commercial conditions, the adaptation of scientific business principles to a highly specialized industry, and the furnishing of trained men for putting these discoveries into execution; and, finally, the College has set a mark to shoot at in respect to the quality of dairy products. In fact, so intimately are these contributions woven into the whole structure of dairy manufactures that their source is scarcely recognized except on occasions of this kind when we are taking inventories. In closing, it should be said that the dairy industry, as never before, is looking to the Agricultural College for assistance in the solution of its problems as well as for the training of its men, and there is no doubt that when the resume of the activities of the dairy industry is written for the next twenty-five years, it will contain in large letters the name of the Agricultural College. 


\title{
DEVELOPMENTS IN HORTICULTURE
}

\author{
J. C. BLAIR, Professor of Horticulture
}

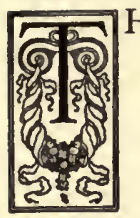

HE HORTICULTURAL developments of our state started with the organization of the State Horticultural Society in 1864, and the opening of the Illinois Industrial University in 1867, when instruction in horticulture and botany was made a regular part of the program of state education. The progress made during the first quarter-century of this time was slow, both as regards the commercial development and educational developments in horticulture. Of course, the commercial development has been largely the outgrowth of the educational advancements which have taken place through the state organizations and the State University.

In 1877 , ten years after the University had started, nine students were registered in the horticultural courses; and eighteen students, including the special students, in agriculture. The total appropriation for the Horticultural Department was seventy dollars and receipts for that year netted not quite three hundred dollars. At this time, be it remembered, and for many years to come the College of Agriculture was divided into two schools, the School of Agriculture and the School of Horticulture. The object of the School of Horticulture was to afford a scientific and practical education specially adapted to the wants of those who cultivated garden and orchard plants, or wished to manage nurseries, parks, and pleasure grounds. The instruction was both theoretical and practical. The classroom recitations and lectures were supplemented by practise in the fields and plant houses. The technical studies pursued were: elements of horticulture; pomology and forestry; plant houses and management; landscape gardening; floriculture; and horticultural history and rural law.

It was not until 1896, with the reorganization and reestablishment of the College of Agriculture at the University, that horticulture was truly given that impetus which would justify its place as a permanent factor in any system of state agricultural development. It is therefore simply to the last twenty-five years of our history that we look for any record of real achievement.

\section{Conditions Twenty-five Years Ago}

Twenty-five years ago with a large acreage in the state devoted to orchard fruits, small fruits, and vegetables, and with almost no 
development in floriculture and landscape gardening, the cultivation, pruning, and spraying of orchard trees was wholly unknown. Indeed, at that time, it was thought that there never would be need for the spraying of-even apple trees. True, apple scab fungus had been studied, and some suggestions for its control had been made. But, as late as 1896 not much attention was given it in the department curriculum, in which were offered the following courses: orcharding and grape culture; plant propagation and small fruits; vegetable gardening; forestry; landscape gardening; economic botany; special investigation and thesis work. Two graduate courses: studies in combating fungus, insect and other enemies of plants, including spray materials and methods; studies in plant breeding, hybridization, and self- and cross-fertilization. But, according to the report of the President to the Board of Trustees: "The Horticultural Department had been busy in removing useless trees and hedges, renovating orchards and sod, trimming borders, repairing walks and drives, and in giving things a general air of tidiness. In the spring, plantings of small fruits will add to the attractiveness of the gardens and be in a sense something of an experiment. The possibilities of straightening trees that had commenced to lean to one side is being tested." It is interesting to note that by the next year (1897) the plantings of varieties of small fruits had been extended, and more careful investigations were made into the results of spraying.

During the years 1895 and 1896, not more than three knapsack sprayers were in use in the state. One of these was used by George W. Endicott, for spraying his vines at Villa Ridge, one by the Department of Horticulture at the University, and the other by Worthen in his grape growing in the Navoo region. The first spraying with a barrel-pump was done by the writer in the orchard of Valentine J. Kiem, near Quincy, November 11, 12, and 13, 1896. The first knowledge of the presence of San Jose scale in the state of Illinois was had upon the examination by the State Entomologist of some twigs sent in by Mr. Kiem. The spray material used in this first work against the San Jose scale was whale-oil soap, in a hot solution prepared by dissolving two pounds of soap in one gallon of water. The following spring (1897) permission was granted the writer to carry on experiments for the control of apple scab and codling moth in the orchard of H. M. Dunlap, at Savoy. This work was continued for a series of years and the results published annually in the transactions of the Illinois State Horticultural Society and in the Experiment Station reports. 
Within the ycar 1898, a representative of the Department had visited nearly two hundred fruit plantations in forty-seven counties of the state for the purpose of studying the horticultural conditions. A practical demonstration of the methods of spraying was made in Johnson county, at the time of the meeting of the Southern Illinois Horticultural Society. The exhibition created great interest and elicited many questions. Many requests came in for its repetition; but expenses made this impossible. Another subject that occupied a great deal of attention at this time was orchard cultivation. During the school term there was taught the "largest class in horticulture ever in the University; namely, fourteen students, besides those of the Winter School." Two publications, one on "Orchard Cultivation," and the other, "Spraying Fruit Trees," were issued at this time.

\section{Developments in Pomology}

The most pressing problems in fruit production in Illinois have been those affecting the control of insect and fungous pests, and the regulation of the supply of plant food. The early problem in orcharding, therefore, was largely that of protection. It is estimated that the commercial apple crop of Illinois amounts to more than ten million dollars annually, exclusive of the fruit sold locally from farm orchards. Without the protection afforded by spraying, insect and fungous attack would no doubt make apple growing in Illinois an impossibility. In the year 1898, the loss from apple scab alone amounted to $\$ 3,500,000$; while by 1900 bitter rot had gained such headway that the annual loss due to that disease alone, was estimated at $\$ 1,500,000$.

In 1901, Illinois ranked third in horticultural importance, with a larger apple acreage than any other state in the Union. Owing to the great loss from bitter rot the preceding year, and the fact that nothing was known about the disease, orchardists were altogether helpless before its ravages. The Experiment Station, realizing the great need for help, inaugurated experimental work in twelve orchards throughout the state to study a means of control for this fungous disease. At the close of the first year's experimental work good progress had been made but the fact remained that much was yet to be done before the problems connected with the disease could be considered solved. A brief circular describing the discovery and giving prompt advice to growers was issued and further tests and information were published about fourteen days later (July 15 and 29, 1901). 
About the same time the problem of fruit storage came up for investigation. Fruit storage is a most important problem, especially for the apple growers in Illinois, because of its direct bearing on the profit of their business. Storage facilities in Chicago were perhaps three hundred thousand barrels, and in the state six hundred thousand barrels; yet this was entirely inadequate to meet the need. In order to investigate this problem, a storage house was built at Neoga, and storage cellars at Olney, Champaign, and Savoy.

Experiments in spraying for the control of apple blotch, conducted in 1913, showed that from twenty-five to fifty per cent of the crop could be saved from apple blotch in severely infested orchards; experiments in 1916 showed that ninety per cent of the fruit might be saved from this disease; and further experiments in 1917 and 1918 have confirmed the above results. Investigations have further shown that spraying with the proper materials at the proper time will save from fifteen to twenty-five per cent of fruit from codling moth; and it has also been shown that from twenty-five to fifty per cent can be saved from apple scab. The Illinois Station has experimented and published more extensively on spraying for the control of apple pests than has any other experiment station.

The most significant problem in orcharding is production: increased planting and increased yield. Experiments inaugurated in a large commercial orchard at Neoga in 1913, showed as a result of five years' work that the addition of nitrogen to the soil in the form of sodium nitrate, stable manure, and leguminous green manures, had increased the yield of apples by twenty-seven barrels per annum. Practically all bearing orchards in Illinois need fertilizing. From the fertilization of peaches even more significant results have been obtained on the farm at Olney. Altho the peach orchard was only four years old (planted in 1916), and bore its first crop in 1920, the best fertilized plot yielded at the rate of 125 bushels per acre more than the poorest unfertilized plot. This same plot yielded 204 bushels more per acre than another plot (not the poorest) which had been cultivated and fertilized according to the methods in vogue in the cultivation of this fruit. Ten acres of land and twelve hundred trees were used in this experiment. Increasing the yields of the suitably located peach orchards of Illinois by such increases as were obtained in the experiments above described would mean an additional profit of $\$ 700,000$ to $\$ 1,500,000$ to the industry, in all favorable seasons.

In a bulletin of the U. S. Department of Agriculture (No. 767) by the Fruit Crop Specialist, Bureau of Crop Estimates, we find the 
following statement: "From the standpoint of total production, Illinois leads all the Middle Western States, and its summer apple region in the southern part of the state is one of the most important in the United States. In Illinois, as in all Middle Western States, the question of sprayed and unsprayed acreage is important in considering the commercial apple industry, especially since so many one-time commercial orchards all through the Middle West have been left unsprayed and uncared for, and are rapidly losing their commercial importance. However, a more recent revival of interest is responsible for greater care being given to the remaining orchards, and an important place is being assured for Middle West apples."

The first great Illinois Apple Show was held November 19 to 23, 1918, at the Morrison Hotel, Chicago, being promoted by the Illinois State Horticultural Society and held under the auspices of the State Council of Defense. Since that time many excellent horticultural shows have been held in connection with county and state fairs and in many of our large commercial centers.

In 1917 and 1918, investigations were made on drying apples in a convenient and attractive form, and a new and successful process was developed and described. This study indicates that the apple may be preserved for long periods of time in a form superior to ordinary dried apples. This experiment, tho important in itself, also opened up a very large field for research and investigation on the utilization of fruit by-products and on the manufacture of various products directly from fruits themselves. Laboratories for further prosecution of this and similiar lines of investigation and for teaching are now nearing completion as a result of an appropriation of $\$ 260,000$ by the last General Assembly.

In 1899 there were, in Illinois. 16,794 acres devoted to small fruits, valued at $\$ 13,602,676$; in 1919 there were 11,723 acres valued at $\$ 1,109,747$; and in 1920 we find 11,215 acres valued at $\$ 2,064,524$.

Through the encouragement given the originator (Reverend Reasoner) by the Department of Horticulture, the original Dunlap strawberry plants were saved for further test and propagation. The Dunlap variety, which originated at Urbana, was introduced in 1900 , but had been under observation by Burrill and Blair since 1896. It is the leading variety grown in the North-Central states; it is very hardy and productive, and the most resistant to disease. It is successfully grown over a larger range of territory than any horticultural variety yet introduced. 


\section{Developments in Olericulture}

There is another phase of the agricultural development of the state, particularly the southern third, that is of even greater importance than the orchard interests. Reference is made to the vegetable industry. The value of the annual vegetable crop in Illinois exceeds sixteen million dollars. Among the states of the Union, Illinois ranks fourth in value of vegetables produced.

In the spring of 1900 a campaign for the improvement of home vegetable gardens on Illinois farms was started. A demonstration garden was planted, and was.maintained for five years. This served, not only as a model for students and for visitors at the University, but furnished data for two publications showing the large profit that may be secured from a properly managed garden on the farm. Laborsaving methods of planting and tillage were employed. The garden as a factor in food production for the Illinois farmers' family is now admitted to be of much more importance than it was considered twenty-five years ago. The University has had a large part in the shaping of this sentiment.

In 1907, at a time when the melon industry of the state was threatened with destruction by the fungous disease commonly called "rust," the Department introduced the rust-resistant type of muskmelon among Illinois growers. This type of melon has now become the dominant one used by commercial growers, and has made it possible to continue growing melons where the old types have entirely failed.

Better methods of grading, packing, and marketing fruits and vegetables, have been consistently aided by the Department. Bulletin 124 , issued in 1908, contained the first descriptions of grades of muskmelons ever issued in America, and the first definite directions for the proper packing of basket melons of different sizes. In 1910, after five years of experimental work, spraying was announced as a definite method of controlling the leaf spot of tomatoes. The working out of this method of control for this disease is a distinct contribution to the means of maintaining a healthful food supply for the Nation. After five years of experimental work with muskmelons, an economical yet efficient method of fertilizing this crop was reported in 1912. In 1914 , the results of six years of experimental work with onions was reported. Of special importance was the account of the growing of ripe onions from sets. This method of producing dry onions had been given practically no attention previous to these experiments. Its advantages were clearly shown by the results obtained; and now the 
method has been quite generally adopted by market gardeners for the production of an early crop. As a result of careful selections through a series of years, in 1917 two wilt-resistant strains of tomatoes were secured. These strains were developed in the badly infested regions of southern Illinois, where the wilt had become a serious menace to tomato culture, and have proved remarkably resistant to this disease, wherever grown. The use of these strains for avoiding loss from wilt, and spraying for control of leaf spot make it possible to grow good crops of tomatoes under adverse conditions.

\section{Developments in Floriculture}

Floriculture is certainly the most attractive division of the subject of horticulture, as well as the most important commercially, taking the country at large, but its difficulties and problems probably outnumber those of any of the other divisions. When one considers the fact that its operations are carried on, not only in the open, but under the most exacting conditions in glass houses, one is confronted with the fact that here arises a new set of problems demanding consideration and solution. In 1899, Illinois had not quite seven hundred acres of land devoted to flowering plants, valued at $\$ 1,894,960$. Looking at the Census report for 1910, with its 1,339 acres of Illinois land devoted to flowers; and then in 1920, with 19,626,091 square feet under glass and valued at $\$ 9,987,606$; it will be seen that the development in floriculture in Illinois has been a very rapid one. In 1907, the Chief of the Bureau of Plant Industry, placed Illinois as first in the area under glass devoted to commercial flower growing. The retail value of flowers and plants sold in Illinois increased from nearly three million dollars in 1900 to four and one-half million in 1905.

In the floricultural development at the University of Illinois, some very important results have been obtained in the investigations with fertilizers in their relation to the production of cut flowers. From a three-year project on the effect of acid phosphate, it was found that production can be increased in a profitable way. An increase of five per cent in the production both of carnations and of roses, resulted from the application of fertilizers; bulletins have been issued covering these results. From experimental studies made to test the effect of using the same soil in the benches continuously for several years, it was found that the plants grown on the second-year soil were in every way as productive as on new soil. Since 1917, the study with carnations and rose plants to determine the effects of se- 
lection upon production have been continued. Such study as has been made to determine the possibility of eliminating certain physiological diseases from greenhouse crops by means of plant selection, indicates success by this method.

\section{Developments in Plant Breeding}

In plant breeding results are slow, for they are contingent upon the fruiting of hybrid progeny. In crossing hybrids, two difficulties are encountered; namely, obtaining the desired pollen at the right time, and sterility of many of the hybrids. The appearance and performance of first generation seedlings serve in some degree to indicate the vitality of parent plants and the stability of their characters. For this reason, effort centers upon production of second-generation seedlings for as many of the more promising groups of hybrids as possible.

Apple hybridizing was begun in 1909 , since which time nearly fifty thousand flowers have been pollinated. Twenty-three per cent of these pollinations have been successful, that is, fruits have matured and been harvested. There are 814 different groups of hybrids represented. The same varieties and species, tho often not the same individuals, are used year after year. The seedlings range in age from one to twelve years. Fruits from sixty-eight hybrid seedlings possess sufficient merit to warrant propagation and further trial. These trees vary, in season of fruit maturity, from early summer to late winter; each is a potential new variety; these are being tested with reference to productiveness and to the keeping quality of the fruit.

\section{Developments in Landscape Gardening}

As early as 1868 a course in landscape gardening is mentioned as part of the work in horticulture. In 1869, the Third Annual Circular of the Illinois Industrial University, announces that the "School of Horticulture will include the formation, management, and care of gardens, hotbeds, orchards, tree plantations, and ornamental grounds." By 1871 there had been mapped out a much more complete course of study, and we find for the junior year, second term, a course in garden architecture; third term, "landscape gardening," with the illuminating remark that "Ladies and gentlemen alike engage in the studies and exercises of the course." Five years later, the circular announces that "Eleven weeks are devoted to the study of 'Landscape Gardening.' " But since only twenty-four men were registered in the 
entire "School of Agriculture" and two in the "School of Horticulture," it is doubtful if much of value was worked out.

In 1888, landscape gardening was taught during the spring term by lectures and practical work. After a study of the materials, including grass, trees, flowers, substances used for walks, drives, fences, and other architectural features, the method of designing and drawing plans was taken up and put into practise. In 1895, a course "Gardens" was announced. A year later the writer was appointed instructor in horticulture, and again a course in landscape gardening was offered. This was described as a course on "Ornamental and landscape gardens," with reference to the treatment of home surroundings. It was not until 1904 that the exigencies of the case seemed to demand a special instructor to teach landscape gardening. In 1907 and 1908 five new courses were added, and in 1912 there was sufficient demand for the work to launch landscape gardening as a separate division. The significant thing is that the University of Illinois now has the leading department of landscape gardening in the country, both as to variety and character of the work offered and as to number of students enrolled.

Many of the pioneers in Illinois advocated and practised the planting of other than fruit trees, but only for shelter and timbernot in an ornamental way. Public parks were unknown. Some towns or villages had a public square upon which there was built, or to be built at some future date, a county courthouse or the like, and here a few maples or elms were usually planted. On school grounds, if anything was done at all, a few forest trees were planted. The attempts of the housewife for beautification in this new country were very simple. Rapid development, however, was destined to take place. Towns and cities sprang up almost as if over night; and it is here that we look for the earliest development of ornamental horticulture, landscape gardening, and adornment of home grounds. The real effort in landscape development was ushered in with the coming to our state of the great Columbian Exposition held in Chicago in 1893. It was the tireless work of Olmsted, and later, of quite a few distinguished artists, that planned and opened a way for new realizations in our parks and other made-landscapes. They gave the world a vision of supreme beauty, which was to be the inspiration of the century and its most priceless gift to the coming days, in an artistic sense. The Exposition aroused the pride and spirit of cities throughout the Middle West. A few years later Chicago instituted a commission to consider a plan for the development of the city, and to es- 
tablish playgrounds. This work is now progressing rapidly.

Landscape development was also fostered by the desire of historical associations to preserve for future generations the old landmarks in Illinois history. The restoration of the "rocks" along the Rock river, lake bluffs, river banks, ravines, sand dunes, and bits of natural woods was carried on. The Illinois Chapter of the Daughters of the American Revolution made possible the restoration of the old Fort Massac, located on the Ohio River near Metropolis, Illinois. The planning and the execution of this work was done by the speaker. It seems safe to say that much of the rapidity of development in landscape gardening, in its various phases, is due to the combination of the theoretical and the practical. In the professional field many of our graduates have been real influences in the building of a better and more beautiful Middle West.

All organizations and state agencies, including the University, should do everything in their power to make our farms, our country places, beautiful as well as economically and efficiently arranged and more healthful places in which to live. The coming generations, as well as the present, have a right to expect this. With further expansion of our horticultural developments, Illinois will shortly be the most beautiful country in the world. It is essentially a horticultural state, where all sorts of horticultural products reach their highest development. The agriculture of the future will be more intensive agriculture and less extensive. This means small and better developed farms, with a richer, more healthful and beautiful home life. I am glad to have had a part in the developments of the past, some of which have been briefly touched upon here; and it is my earnest desire to further in any way possible future progress in horticulture. 


\section{THE WORK OF THE AGRICULTURAL EXPERIMENT STATION}

\section{H. Smirh, Chief in Charge of Publications of the Soil Survey}

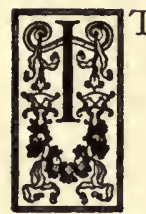

T IS my privilege to review the work of this Experiment Station since its foundation and to present briefly its outstanding accomplishments. The Illinois Agricultural Experiment Station was organized in 1888. For a record of its achievement one naturally turns to its published reports. I find that during the thirty-four years of its existence there have been published 237 Bulletins and 19 Soil Reports, aggregating altogether 9,806 pages of printed matter. This may, for present purposes, be taken as a quantitative measure of its scientific output. I am sure you will appreciate the compound problem that I have before me; first, in selecting from this array of material that which is most significant, and second, in presenting the same in the allotted time.

Following the custom of the experiment station investigator to do his work, as well as his thinking, within somewhat discreet units known as "departments," I have decided to take up the consideration before us somewhat on the departmental plan. For our purpose, however, we need not make our departments quite so "watertight" as critics of the system have sometimes implied it to be. Therefore, for convenience in considering all this experimental work that covers such a wide range of subjects, suppose we take up these investigations under the following groups: soils, plants, animals, and farm organization. This system is sufficiently comprehensive, and it would seem to be a logical one, for first, we must have the soil in order to grow plants; then we must have the plants in order to raise animals; and finally, there should be some sort of a correlating agency, such as a department of farm organization. Moreover, this grouping has an advantage for the particular purpose in hand, over one based upon the existing plan of departmental organization, in that much of the past work that we are to consider was not done by the departments as they now exist; and it would not be altogether fair for them to assume either the credit or the responsibility.

\section{SoIL Investigations}

Taking up that subject first that lies at the foundation of all production, let us make a hasty survey of those investigations pertaining to the soil. 
This Experiment Station was so fortunate as to inherit at its birth the oldest soil experiment field in America. The series of plots now known as the Morrow plots had been laid out by Professor George E. Morrow and had been running about a decade previous to the founding of the Experiment Station. Who would be bold enough to attempt to assess the value of these old plots? The records of all these years show, on the one hand, how this rich prairie soil of Illinois can be abused through improper management; or on the other hand, how it can be built up by proper treatment. For example, in 1919 the old untreated continuous-corn plot at one end of the series yielded twenty-eight bushels of corn, while the plot at the other end that has been fertilized and kept under a favorable crop rotation gave seventy bushels, - and forty-one years before this, these two plots lay in the same field.

Another set of plots on the University campus, forming a more extensive series, but of more recent origin, are the Davenport plots laid out by Dean Davenport about twenty-five years ago. Both the Morrow and the Davenport series, as we now see them, are what is left of a much larger original layout. In both cases the plots have been reduced in number with the demands of campus developments. Thousands of farmers every year witness the lessons in soil management as they visit these plots. It would seem that whatever else is changed on this campus, these old plots should be preserved for the benefit of the generations to follow.

It was in the year 1900 that Dr. Cyril G. Hopkins was appointed to the chair of agronomy and took up his great life work in the study of soils, and at about this time the state made its first generous appropriation of a special fund for soils investigations. In pursuing the investigations of the soils of Illinois three main lines of procedure were inaugurated; namely, the soil survey, field experiments, and pot culture investigations. In the soil survey the various kinds or types of soil are classified and mapped in such a manner that when the survey is complete every landowner in the state will have a description of the soil on his farm, will know approximately its composition, and will have at hand information relating to its maintenance and improvement. This work has progressed so that now eighty counties of the state have been mapped and published reports for nineteen counties have been issued.

Field experiments, serving for investigation as well as for demonstration, were undertaken on the more important types of soil. The number of these fields has increased until there are at present about 
forty distributed on different soil types over the state. On these fields such problems as relate to plant-food requirements, proper systems of crop rotation, drainage, prevention of soil erosion, subsoiling, and dynamiting are being investigated. As an indication of the growth in popularity of these fields it may be said that when this work first started it was difficult to obtain land for the purpose, sometimes even by offering a fair rental price, but after a few of these fields had been established and had begun to demonstrate their value, the popularity of this work grew to such an extent that finally the University came into the position of being able to demand some form of permanent tenure, either by deed or by permanent lease, before it would accept a piece of land for these experimental purposes.

\section{A System of Permanent Fertility}

As the results of his investigations accumulated, Dr. Hopkins gradually evolved a philosophy or doctrine of soil fertility intended to apply to the normal soils of Illinois and of similar areas. His dominant idea was to provide a system of soil fertility that would result in a permanent agriculture. He recognized that the continual removal of crops from the land must finally lead to soil exhaustion unless the materials taken from the soil be restored. The common practise of applying commercial fertilizers returns to the soil some of the necessary elements, but not in amounts proportionate to the quantities removed by crops, thus producing the effect of a stimulation of the soil rather than that of a sufficient supply of plant food. By restoring the elements to the soil somewhat in excess of the amounts in which they are removed by cropping, the soil is not only maintained in its natural fertility but is actually built up and made more productive. In order to accomplish this effect the elements must be secured in the most economic form, which ordinarily calls for raw materials rather than those that are treated or manufactured. Thus in ordinary cropping systems, raw rock phosphate should be used and the natural biological process of the soil will make the phosphorus available. Nitrogen should be secured from the air through the growth of legume crops. Potassium is abundant in most normal soils and the problem of supplying this element is usually a matter of liberation from the minerals naturally present in the soil rather than the addition of potassium salts. In order that these natural biological processes may function properly, the soil must be kept supplied with an excess of basic material, and for this purpose natural crushed limestone serves best. 
This is an attempt at a very brief statement of the fundamental or guiding principles of Dr. Hopkins' proposition of a permanent system of agriculture. There are hundreds of deviations in details, most of which are yet to be worked out. Such details will vary with different types of soil; they will vary with the kind of enterprise followed, whether grain farming, live-stock farming, or fruit farming; they will vary with different economic situations, such, for example, as affect the accessibility and the cost of different forms of fertilizing materials. And so, while we may consider that the great idea of a permanent system of agriculture, and the fundamental principles for carrying it out, may be counted among the finished problems of this Station, in reality the work on this problem is only well begun. The foundation is laid, so to speak, but the great super-structure is yet to be erected before Illinois agriculture as a whole shall be actually upon a permanent basis.

One of the chief questions among these unsettled problems is how to maintain the nitrogen supply and this has been the subject of much study. As an example along this line, a discovery of greatest practical importance was made when it was found that the organism acting on the roots of sweet clover also inoculates the alfalfa plant. This has been followed by similar discoveries relating to the bacteria of other legumes. The most recent investigations of the division of soil biology are revealing very practical knowledge of the most advantageous ways of handling legume crops looking toward the solution of this great nitrogen problem. Numerous other investigations under way looking toward the solution of many of these unanswered soil problems might be mentioned if time permitted.

\section{Plant Production}

Turning now to that phase of our discussion that has to do with plant production, let us consider next some of the work relating to field crops.

The introduction of properly adapted varieties, especially in corn, has been a large factor in improved production. The attention paid in recent years to the vitality of the seed must also have had a tremendous influence in this direction.

In corn breeding this experiment station was a pioneer. The long-time selection experiments in corn to change the composition of the grain have attracted world-wide attention. This investigation has been continued through twenty-five generations of breeding, with unbroken pedigree records, and the result has been a most remarkable 
response to the selection. Starting with a single variety of ordinary field corn, four different kinds have been created, one of which is now about twice as rich in protein as another, while another strain now carries about five times as much oil as its corresponding opposite.

As another example of the possibility of improving our field crops through the methods of plant breeding, may be cited the production of the new variety of wheat designated as Turkey 10-110. This wheat is the progeny of a single mother plant found in a field of common Turkey Red in 1910. Following its favorable performance in the breeding plots, where, as a six year average, it outyielded the parent variety by six bushels per acre, the strain has been increased and thousands of bushels of seed are now being distributed about the state in those sections to which it is found to be adapted.

For the introduction of certain valuable new crops, the Experiment Station has been largely responsible. Among these crops that have been established in Illinois may be mentioned the soybean and sweet clover, while the sunflower promises to take an importnat place as a silage crop. Sweet clover deserves, perhaps, more than a passing mention; for, in the mind of the writer, the introduction of this remarkable plant marks an epoch in Illinois agriculture in the sense that we have adopted a.plant that not only possesses great value as a forage crop but also one that, when properly handled, goes a long way toward solving the nitrogen problem.

As an outcome of some of the earlier investigations and the subsequent propaganda throughout the state, we have the improved practise of the shallow cultivation of corn, as against the old "rootbutchering" method of deep cultivation. It is doubtless true that to this one thing alone Illinois and other corn-growing states are indebted for millions of bushels of corn annually in increased yields. Many other important experiments having to do with the planting, cultivation, and harvesting of our common farm crops would be well worthy of mention here if the opportunity permitted.

\section{Horticultural Crops}

In the production of our horticultural crops, which include the fruits, vegetables, and ornamental plants, many investigations parallel to those described in field crops have been carried out. To give some idea of the extent of the activities along this line, it may be said that nearly fifty bulletins have been issued covering a wide range of topics related to one phase or another of horticultural production. Fertilizer experiments have been conducted in the orchard, in the garden, and 
in the greenhouse; varieties have been tested; the cultivation of orchards has been investigated; systems of garden planting have been tried out. In plant breeding, very extensive investigations in the breeding of fruit trees are under way. As products of this work an instructive bulletin on "Apple Bud Selection" and another on "Seed Production in Apples" have been published.

As might be expected, a very large volume of the work with these horticultural crops has had to do with their protection from diseases and insects. For this work the Illinois Experiment Station has been peculiarly fortunate in having had the life-long service of two of the foremost scientists-indeed, world authorities in their respective fields - who have devoted themselves to a study of plant protection from bacterial and fungous diseases, on the one hand, and from insect ravages on the other. Hundreds of appreciative farmers from all over Illinois as well as from other states honor this grand team of workers-Thomas Jonathan Burrill and Stephen Alfred Forbes.

To Dr. Burrill is given the credit for that great scientific discovery that certain plant diseases are caused by bacterial organisms. It is natural that under such leadership a strong development of this line of work should occur. It is interesting to note in this connection that thirty-four years ago this Station published a bulletin entitled "A Bacterial Disease of Corn" written by Dr. Burrill. Within the past few years there has been a great revival of interest in corn diseases and today "the air is full of talk," on this subject. Likewise many years ago Dr. Forbes began his observations on the insect pests that ravish our crops, and this early work has been followed by that splendid series of studies covering the insect depredations of the various classes of our economic crops, the grain and hay crops as well as the fruit crops.

Thus it has come about that the investigation of orchard spraying for protection from diseases and insect pests has loomed large in the program of our horticultural staff. This work may be briefly summarized in a quotation taken from a recent report.

"Experiments to determine the best methods of controlling insects and diseases attacking apple orchards have been conducted in a systematic manner for the last twenty years, and the results of these experiments have been the chief source of information upon which the apple growers of the state have depended for guidance in their spraying operations. A definite spray program has been prepared which has helped very materially in putting apple growing on a paying basis in Illinois. The commercial apple crop of the state is valued at ap- 
proximately $\$ 10,000,000$ annually, and at a very conservative estimate at least one-third of this value may be attributed directly to the application of the protective measures based upon the experimental work of the Experiment Station."

\section{Animal Production}

Investigations pertaining to the production of live stock has had a large place in the Station's affairs from the beginning. In fact the very first bulletin put out reporting the results of an investigation was on the subject of ensilage. This has been followed by more elaborate studies, increasing in intricacy according to the demands of developing knowledge. During the years under our consideration great changes have taken place in scientific thought relative to food values in relation to composition. We take pride in the progressiveness of our nutrition investigators in keeping up with the procession of changing ideas. They have run the whole gamut of these new ideas, from enzymes and special proteids, to vitamines; and we find their bulletins always making real, up-to-date contributions to the knowledge of their day. In the later experiments on feeding, no little consideration has been given to critical studies of methods used and analysis of results obtained, the importance of which is coming more and more to be recognized in all kinds of scientific research. (I cannot refrain from taking opportunity at this point to observe that if our Experiment Station work is to carry the stamp of thoroness and reliability, the public must exercise some patience at times in awaiting results that must first be scrutinized for scientific accuracy by the best methods known to science before they are given out for publication.)

The improvement of live stock through breeding has also received attention, and many splendid specimens of their respective classes have been produced. Through the establishment of a division of genetics, thorogoing investigations have been undertaken to learn the fundamental principles underlying the art of breeding. Just so far as these genetic principles are discovered and applied, just that much will the breeding art be advanced.

A most practical experiment in the breeding of cattle to learn the genetic behavior of the milk-producing functions of the dairy cow is now in progress, and the information to be derived from these experiments must have a far-reaching effect upon the future dairy industry. 
A division of animal pathology has only very recently been established. However, its influence has already been felt, not only within the state, but throughout the country. The importance of its investigations of the botulism disease, which has resulted in the saving of human lives as well as of animals, has attracted widespread publicity.

As among the most appreciated investigations of the Station, because of its direct practical significance to the live-stock industry of the country, must be mentioned the work reported in that fine series of bulletins dealing with the market grades and classes and of the various kinds of live stock: horses, cattle, swine, and sheep. This work has been of untold value in bringing order out of what was formerly chaos in the marketing of live stock.

The dairy cow came in early, and has remained through the years, for a large share of the Station's attention. The long series of investigations on the individuality among cows as to milk production, with the propaganda against the "boarder cow" has had a profound effect on the dairy industry. It has led to that modern device for dairy improvement known as the cow-testing association, and "boarder cows" by the hundreds are being led to the shambles.

Another activity for the benefit of the dairy industry has been the incessant war waged against unclean and unsanitary milk. Mention should also be made here of the studies in the economics of milk production, for the data stand as a source of information not alone for the dairyman but also for the benefit of the general public in the solution of problems pertaining to its economic welfare.

\section{FARM ORganization}

We come to the last of the divisions of our discussion; namely, farm organization. The department representing this work in the Experiment Station is still very young; nevertheless, it was "well born" and got into action promptly, so that it is already making contributions for the solution of those agricultural problems that lie within its province. Its studies in cost accounting have been of direct value in leading to better methods of land valuation. They have also been helpful in developing plans looking toward the stabilization of markets. A special study has been made in comparing tractors and horses as sources of farm powver. As time goes on, the agricultural public will look more and more to the Department of 
Farm Organization and Management for information along many lines, to assist in solving its economic problems.

\section{Conclusion}

In dealing in this hasty way with such a variety of topics in an attempt to cover the ground, I realize that this discussion must read somewhat like a dictionary. I also fully recognize the fact that I have been unable to do justice to many of the topics mentioned; and further, that injustice has been done in the omission of many topics that might have been mentioned. The particular points mentioned were selected largely to serve as illustrations. Another person would doubtless have selected other points for mention. Therefore no one should infer that this brief review is intended to be a perfect epitome of the Experiment Station's most valuable work.

It is unfortunate that we have no very satisfactory device for measuring, either in terms of bushels or of dollars, the tremendous returns resulting from these investigations. Stories of this kind are usually made more interesting by translating into terms of millions of dollars. Having at hand in most cases no sound basis for such a translation, I have necessarily been contented in setting forth the economic value of these investigations in rather general terms.

If in this hasty review there has been left a general impression of the nature and the scope of the Experiment Station work, during its thirty-four years of existence, the purpose will have been accomplished. 


\section{THE WORK OF THE COLLEGE OF AGRICULTURE}

\section{Fred H. Rankin, Superintendent of Agricultural College Extention}

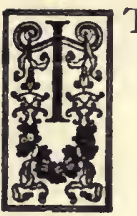

$T$ has been the destiny of Illinois to be intimately associated with that great educational movement which culminated in "An Act donating public lands to the several States and territories which may provide Colleges for the benefit of Agriculture and the Mechanic Arts." There is an inscription upon the cornice of the Agricultural building of the University of Illinois which reads "Industrial education prepares the way for a millennium of labor." These words of Jonathan B. Turner, of Jacksonville, who was intimately associated in the establishment of the Land Grant Colleges, stand forth as a constant reminder that the material resources of a people can never be fully developed without the aid of trained intelligence.

The University of Illinois, known at that time as the Illinois Industrial University, first opened its doors to students in 1868. Agricultural education and the direct application of science to the affairs of agriculture have come up in our country through great tribulations. The early records show that when the institution was first officially opened, Willard F. Bliss, of Nokomis, Illinois, was elected professor of agriculture. He was a graduate of Yale College, had traveled extensively, was trained in the classics, and was owner and manager of a large farm in Montgomery county. Mr. Bliss took up the task assigned him with much hesitation. Actual contact with the matters involved did not decrease the difficulties, and at the end of his first year he considered it necessary to return to his own home.

Jonathan Periam was the first real employe of the Agricultural College. He served in this capacity until March, 1869. In 1870, Dr. Manley Miles was made professor of agriculture with the understanding that he should serve during the fall and winter months, dividing his time between the Michigan Agricultural College and this institution. However, later it became understood that Dr. Miles could not accept this engagement. Strenuous efforts were made to fill his place. Matters drifted for two or three years; and again, in 1874, Dr. Miles served as professor of agriculture. In the meantime affairs of "practical agriculture," as the phrase was, had been intrusted to the head farmer, and one and another such employes, as temporary director of field experiments. 
In 1876 George E. Morrow, then professor of agriculture at Iowa State College, was elected to the professorship in agriculture and retained this office during eighteen consecutive years. $\mathrm{He}$ was a singularly gifted man in many ways, and these included qualifications needful in the arduous and difficult task which he undertook to perform. There were encouragements as well as discouragements. It is not in place at this time to attempt a complete story. However, at the close of his long career, he could not see that in the actual and plainly observable condition of things his expectations had been justified nor his favorable anticipations fulfilled. Too much was expected and the end sought too great. There was a woeful want of understanding in regard to what one man could and could not do. Superficiality prevailed. No one as yet realized the unavoidable cost of agricultural education given in anything like a thoroly sensible way. A lecture room with a desk, some chairs (not very many), a few charts and pictures hung upon the walls, and a half-dozen books upon agriculture,- - these constituted the equipment of the professor of agriculture, aside from a few things to be found in the way of a Jersey bull in the barn and some weedy fence corners around the plots. It was ne wonder that students were few and enthusiasm at low ebb.

Without further enumeration, it may be said that the agricultural education of the first quarter of a century in our. Land Grant Colleges was poor and halting, probably because it was before its time. The inertia of the ages was upon it. There was need of a selfregenerating power.

\section{The First Dean and Director}

It should not be inferred from its faults and deficiencies that little had been done or gained. Yet it is true that there existed a want of apprehension, inconceivable to us today, of things as vital then as now, and in that sense there was somnolence and apathy instead of vision and vigor.

At this stage in development Eugene Davenport was called to the University of Illinois as dean of the College of Agriculture and director of the Agricultural Experiment Station. The new dean had grown to young manhood on a Michigan farm, and had paid his own way through the Michigan Agricultural College, graduating with the class of 1878. He had farmed for ten years on his own account, taught school in winter, and meanwhile as teacher, farmer, and citizen had been vigorously active in rural affairs. 
After serving as professor of agriculture and director of the Agricultural Experiment Station in connection with his Alma Mater, and later spending a year in Brazil, attempting to organize a government agricultural college (which proved premature in that country owing to changing political regime), he had just returned to America by way of England when destiny stepped in, opportunity beckoned, and the broad prairies of Illinois presented their vista. He came; and behold, he found less than a dozen students, no buildings, no equipment of any kind. He was told to go ahead and make bricks, but to make them without straw. Later on, after straw began to be supplied from outside sources as a result of his own activities, there was somewhat of opposition to be overcome from the executive office of the University in its ideals and in regard to the matter of support which the progress of agricultural education required.

\section{Conditions During the Middle Nineties}

Reviewing the condition of things in the middle nineties, the state was preeminently an agricultural one. The people were largely of the progressive type and tendency-a good many of them. The Agricultural College was on the campus of a rapidly growing University. There was sympathy and encouragement on the side of many members of the faculty, notably in the personal interest of Dr. T. J. Burrill. The University was beginning actually to push forward the agricultural interests. Our more progressive farmers, and others whose business or professional activities made them recognized promoters of agriculture, were not numerous in the state, but there were men here and there of real and growing power, enthusiastic rural men who had a force and whose influence had important bearing on subsequent developments. These and other farmers were beginning earnestly to better themselves; they had already in 1895 planned the organization of a State Farmers' Institute, with legislative support. The agricultural press was assuming a more friendly attitude. The state legislature was beginning to demonstrate a new interest toward the University but was yet apathetic toward the agricultural interests.

What if there were no distinctive Agricultural College buildings, no separately designated College funds, but few agricultural students, and little favorable inside or outside consideration?

After the University had been founded for over thirty years, some of the progressive citizens began to realize that they had some personal responsibility in an institution which was supported by them as tax payers. A committee from the State Farmers' Institute and other 
organizations visited the institution, investigated, and reported. It is not necessary to say much about what they found, or rather what they did not find. When the farmers heard about it through their organization, a movement to right things, sane, intelligent, determined, irresistible, was begun.

In 1895 , the trustees had asked the legislature for $\$ 40,000$ for a dairy building. This was scarcely considered. Two years later, they had asked for $\$ 80,000$ for an agricultural building. The effort failed, many farmers and farmers' institutes opposing it. 'Two years later, and for the third time, the trustees asked for an agricultural building, fixing the amount at $\$ 100,000$. The farmers and the State Farmers' Institute officially endorsed the asking; it was supported by every state agricultural organization. A campaign of education commenced throughout the length and breadth of the state. By careful study it became evident that $\$ 100,000$ would not be sufficient to provide what was needed, and the estimate was raised to $\$ 150,000$ during the campaign. Resolutions were passed, favorable to this asking, at every county institute held in the state, with one exception. Finally, the bill passed the General Assembly without amendment and with only one dissenting vote. When this vote was taken and the building planned, there were but nineteen students in the College of Agriculture.

In those days it was easier to build a dreadnaught than a College of Agriculture. Interest could be aroused in two continents in solving a problem of aerial navigation, but it was difficult to get the people to support the proposition of spending money in developing the resources of the country in order to increase the productive capacity of its people,-for in this farmers were not alone interested since in the last analysis all prosperity rests upon a successful agriculture. Agricultural education stands not only for that industry but for all things needful and contemporaneous in the development of intelligent and patriotic citizens. The preponderance of human ideals and human efforts is, I believe, always toward the good; and the prevailing course and tendency of human institutions is toward the better. Enterprises may sometimes seem to go zigzag, to go wrong end foremost, or at times to remain stationary or go backwards; but ultimately we shall get onward and upward. The best things come not at once, but by evolution, step by step, from imperfection to excellence. Agriculture in its beginning was simple indeed; but in its higher development we see it growing complex, comprehensible, drawing to its aid, assimilating, and rendering subservient all our leading sciences of chemistry, 
botany, physics, bacteriology, and becoming in its vast development ultimately the "master science."

In those earlier days we were turning to a new agriculture, an agriculture which was lighted and glorified by science; and to this new agriculture the Agricultural College and Agricultural Experiment Station was to be the main gate way. Many farmers who watched the work of the institution, and who applied to their own business those teachings that might be applicable, soon came to be enthusiastic friends of the institution; and thus was developed a wise public policy which from time to time gave more liberal support to the Agricultural College and Experiment Station. The advocates of this education stood upon the high ground that agriculture and industry in general should be studied toward, and developed from, the standpoint of public policy; and the principle was enunciated that institutions of learning and research existed primarily, not for the benefit of particular individuals, but in order to develop certain fields of knowledge, such as agriculture, science, economics, literature, etc., and to stimulate their influence among the people.

Agricultural education was bringing to the attention of the people a new standard of life for all men. The old idea, held by many, that the highest life consists in withdrawing from one's fellows; in spending one's days in contemplation, in leading a life which begins and ends with the individual in some hopeless attempt to solve the infinite, was fast passing away. Agricultural education introduced into the world the gospel of service and of doing things, and demonstrated that industry and service detract nothing whatever from art and refinement.

New problems constantly arose for adjustment, in taking this education and using it for the benefit of all men and the development of industry. It was found that perhaps the most fundamental means for extending new knowledge among the people is the students who come to the College and are educated in it. These students are not educated so much for their own sake as that they may go out and carry into their generation the best that the present has to give. It is believed that for the business of instruction in general no method of propagating truth among the people is so effective as that which goes out from the classroom and laboratories into the minds and hearts of the young men and women. These young people go out and begin new lives; and while the Experiment Station and the scientists discover agricultural improvements, knowledge of which is spread by means of publications and the Agricultural Extension Service, yet we 
believe that it is safe to say that after all the most powerful agents of progress that the University sends out are its well-trained young men and young women, when they are settled upon the farms of Illinois.

These were the ideals which inspired a few men in those carly days with an immovable determination to develop agriculture and agricultural education in Illinois; and the energy with which they prosecuted this public service in their generation was analogous almost to the energy and faith of martyrs. All honor to the men who in the last quarter century gave so freely of their time and scrvice to this end: Colonel Morrison, W. H. Fulkerson, Lafayette Funk, John R. Tanner, Ames F. Moore, S. Noble King, Charles F. Mills, James H. Coolidge, E. E. Chester, A. P. Grout, L. H. Kerrick, James Carter, Frank H. Hall, Fred Hatch, E. B. Vorhees, H. A. Aldrich, H. M. Dunlap, Jacob Zeigler, H. A. Winter, and many others. In the lead of these men and associated with them have been many others who carried on the work which they so ably began, whose names it would be impossible to enumerate.

\section{The Growth in Students}

Following this renaissance in agriculture in the nineties, there came to the College of Agriculture such earnest workers as Davenport, Blair, Hopkins, Mumford, Frasier, and Miss Bevier; and they in turn brought to the faculty in each of their respective departments an excellent corps of young instructors, many of them already well known for eminent service in agriculture, and all learned and skilled in the art and devoted to it. How rapidly the attendance in the College of Agriculture increased is indicated by the following table:

$\begin{array}{cccc}\text { Year } & \text { Students Registered } & \text { Graduating Class } & \text { Graduate Students } \\ 90-91 & 7 & 2 & 0 \\ 95-96 & 14 & 0 & 0 \\ 00-01 & 159 & 4 & 0 \\ 05-06 & 430 & 24 & 9 \\ 10-11 & 729 & 51 & 28 \\ 15-16 & 1,257 & 188 & 75 \\ 20-21 & 1,184 & 176 & 54\end{array}$

Students are now coming from almost every county in the state, most of the states in the union, and from many forcign countries; and it is significant that over 50 per cent of the four-year graduates are returning and residing upon farms, over 25 per cent are engaged in some phase of agricultural activity, such as county advisory work, teaching of agriculture in vocation schools, or agricultural investiga- 
tion work. Some carefully compiled statistics made just prior to the war revealed the fact that over 85 per cent of the graduates at that time were following agriculture directly or were engaged in some phase of agricultural work.

\section{Some of the Guiding Influences}

The College of Agriculture engages in three distinct lines of work: (1) the regular teaching in college courses of the students who come here; (2) the investigation of and research into agricultural problems; (3) extension work. It is not the purpose of this paper to dwell in detail upon any particular phase of this service, but to touch in a general way upon some of the fundamental things which have guided the policy of the institution. Perhaps it may be said in passing that there ivas a time in the early history when, but for wise direction, the funds available for agricultural education would have been diverted; and instead of there being instruction of University standard, there would have been simply short-course work or high school agricultural courses offered.

While closely related to the Experiment Station, yet we consider that one of the most fundamental policies attempted in the College as well as in the Station is a system which is unique at Illinois, namely, that of having an advisory committee relationship for each of the departments, some three to five representative citizens being invited to act in an advisory capacity with the department whose interests they especially represent. These men are conversant with the practical problems which confront them, upon which they especially desire information. They act as a balance, representing the interests of the practical man as against the man whose thoughts and interests lie more in science and theory. This relationship has been a most happy and profitable one, and it probably has done more toward fostering the close personal interest of the citizens in the work of the College than has any other one thing.

Another most valuable asset has been what is known as the Corn Growers' and Stockmen's Convention, or two weeks course in Agriculture, which has met annually at the University for the past twenty-one years. Several hundred young men and farmers have attended this meeting and have received inspiration and incentive and an insight into the work of the institution which otherwise could not have been attained. In this respect again Illinois has been a pioneer.

As these movements for agricultural education were undertaken, they made a profound impression; citizens welcomed this type of ed- 
ucation more heartily than ever before, and its influence throughout the state was everywhere great. One of the first reasons for this change was that the value of education along agricultural lines was brought more distinctly home to the farmers through the work of the farmers institutes, state agricultural associations, and other early extension agencies. It was no longer simply a question of increased production on the farm; but rather, in addition to that, a building of strong, permanent, and intelligent leadership in agricultural communities, studying and solving those questions which relate to the larger life of our agricultural people; in short, more attention was being given to the importance of the human side of agricultural progress which, in turn, had a profound effect upon the work of all the agencies for agricultural education. This human side of agricultural progress, as contrasted with the narrow question of merely increased production, has had a profound influence in shaping newer lines of extension service, such as a series of one-day farmers' institutes, farmers' clubs, community meetings; specially organized and planned institutes for boys and girls with corn and various judging contests; personal visits to homes; boys' State Fair schools; short courses in agriculture, of which the College conducted over sixty in one year; farmers' encampments; seed, soil, and dairy trains run over all of the principal railway lines of the state; and the organization of excursion parties to visit the University.

\section{The Newer Problems and Lines of Service}

The so-called stock information in agriculture concerning crop production, live-stock judging, soils, etc., is pretty well known. There is active and unanswered as yet a demand for information along such lines as cost accounting, cooperation, marketing, retail delivery service, overland truck service; taxation and public expenditure; housing; and also a demand for a study of conditions within the state, including the sources of raw material, transportation records and rates, variations in retail prices, etc. These are simply a few of the problems that confront us in an economic way that must be solved by the young men of the next generation or two.

Time will not permit the enumeration of the new and large departments and lines of work in the College of Agriculture and the activities which are being directed especially to the betterment of the farmers, along research and investigational lines; nor of the ways in which through the Extension Service it is making known to the citizens of the state the results of its investigations. The courses of 
study as offered in the College are revised from time to time, and standing committees are constantly seeking to study and improve the curricula and methods of teaching. There is offered landscape gardening, which has for its primary object the improvement and adornment of the home ground; the same applies to the curriculum in floriculture. Household organization and activities, and home economics are subjects which apply alike to every household in the state. The work of the College, therefore, in a broad way applies to all citizens and cannot be regarded as favoring one class to the exclusion of another. The Agricultural Extension Service and the county farm advisers are now organized in some ninety-five of the one hundred and two counties in the state.

Citizens of the state visit the University and its Experiment Station in large numbers. It is conservative to say that not less than ten thousand people annually come to the twin cities primarily because of its Agricultural College and Agricultural Experiment Station. The visits to such an institution, if for but a single day, do much in arousing and redirecting the dormant energies of mind.

\section{The Contribution of Eugene Davenport}

The accomplishments of the past twenty-five years in agricultural education have not just happened nor just come to pass; they have been the result of wise guidance and leadership. Somebody's watchfulness, somebody's thoughtfulness, somebody's thoroness is always required. While many men have contributed to the development of agricultural education in the last quarter of a century, I do not feel it proper to make these general observations without referring to the skilful management and organizing ability of Dean Eugene Davenport, who is abundantly entitled to all the credit he may ever receive for the splendid upbuilding of the great Agricultural College of the University of Illinois; and for the unique and unsurpassed service that he has rendered in the promotion of agricultural interests and of the affairs of the state at large. Looking backward it little matters who was governor of the state for four or eight years, but it is of infinite concern to Illinois citizenry as to who for the past twenty-seven years outlined the plans for the development of our agricultural industry, how it should be studied, taught, and developed from the standpoint of public policy.

While agriculture has grown greatly in Illinois, as a result of this guidance, Dean Davenport has also largely contributed to the wealth and worth of community life and social well-being in the way 
of projecting his personality into the minds and hearts of thousands of young men and women and older people who have come into direct contact with him and are proud to do him honor as a modest citizen who has led an inspiring, wholesome life and who has efficiently discharged day by day the duties of his office which he has skilfully administered and so highly magnified. He has established an honorable, rightly earned, and widely recognized name. His ability as an organizer has probably given him a good share of his reputation, and it is no doubt true that some of the larger results of his intelligently directed efforts have been indirectly achieved through the organization and direction of others, while he has been but little in evidence personally, preferring to allow other people to have the credit for what he had really originated.

Gathered here today we see, tho incomplete, an outline of what the founders and leaders of such an institution as the College of $\mathrm{Ag}$ riculture endeavored to establish. Let us in prophetic vision contemplate it as it will appear when generations have perfected it in all its magnificence, its glories, its good to man and to all men of all classes, in its power to evolve and diffuse practical knowledge and skill, culture and appreciation and better love of industry and sound morality, as voiced not only through its research, its instruction, and its extension service, but through its thousands of graduates in every pursuit of life. Then let us seriously ask, is not such an object worthy of at least the best efforts we have and worthy of a state which God himself in the very act of creation designed to be among the leading agricultural and industrial commonwealths on the face of the Globe? 


\title{
NEWER PROBLEMS IN SOIL TREATMENT
}

\author{
Frank I. MANN, Gilman
}

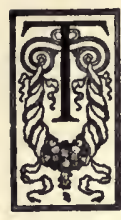

HE GREATEST asset any nation ever had is that which the United States had in the fertility of her soils; it is the basis on which rest all other assets, whether of bank, of railroad or of manufacture. The importance of this asset, and the rate at which it is being exhausted, entitles it to consideration as a national problem, not only for agriculture but for all industries. We are now drawing on this asset and have done so for many years; we have sold the products, for domestic consumption and for export, for less than any reasonable cost of replacement. This is a wanton waste, which must some time be reflected in the decreasing prosperity and happiness of the people. The value of this asset is largely expressed in the organic matter of the soils; and that which is of greatest value in the organic matter is the element of nitrogen. The ultimate problem in food production is the fixation of atmospheric carbon by the plants, and when we remember that, as a broad proposition, nitrogen, with a small amount of minerals, is the usual measure of the fixation of carbon, we can realize the great importance of its maintenance.

It has been estimated that the virgin soils of the United States contained about 550 million tons of the element nitrogen; and they are now estimated to contain about 275 million tons, which is a reduction to one-half the original amount. When we spread this present total over all the cropping land in the country, it gives an average of about 2,000 pounds per acre; and when we make allowance for the larger amounts in the richer soils of what is termed the corn belt, the northwestern wheat belt, and the alluvial soils variously distributed, it gives about 1,500 pounds per acre for the remaining land, which constitutes by far the largest area. This area largely comprizes the Eastern states, the country south of the Ohio and Missouri rivers, and parts of the states bounding these rivers on the north. This means that the lands in this large area do not now contain enough nitrogen to give fair returns from their operation. These figures indicate that we have already exhausted about one-half of our greatest national asset.

If we take the total crops produced each year and calculate the total amount of nitrogen required to form the finished product, we have a total of about three million tons; that is, there is annually removed from the soils about this amount of nitrogen. If we calculate, 
as best we can, the amount returned from various sources, in legume crops, farm manures, and several forms of commercial nitrogen, it seems impossible to reach a total of more than two million tons; this leaves an annual deficit of about one million tons of nitrogen. When we remember that production is based on the use of a small percentage of the total supply each year, we can realize better the importance of having a large total supply in order that the small percentage may be adequate for profitable production. I am aware that some of these calculations have been made from rather crude data; but it is one of the problems of agriculture to ascertain the truth, and to either disprove or confirm the calculations al ready made.

\section{The Problem of Maintaining and Increasing the NrTROgen SUPPLY}

The problem of the nitrogen supply naturally divides itself into two lines; one, the conservation of the natural supply; the other, a restoration through new supplies. As the nitrogen is included in the organic matter of the soil, it is a frequent custom to apply various agents to those soils low in organic matter that will hasten the decomposition of the organic matter, so that more nitrogen can be recovered than under natural processes. The agents so used are acidulated fertilizers, green cover and catch crops plowed under, lime in caustic forms; and sometimes even clover and farm manures are used for the purpose. On much of the poorer land, where the amount of available nitrogen is the measure of crop growth, it is being found more profitable to continue the process of breaking down the organic matter by using more and more of these agents designed to secure nitrogen, than it is to supply nitrogen. In the end, and the end is coming soon on much of the land, the organic matter becomes so low that stimulation is not effective, and complete fertilizers must be used to provide each deficient element in the quantity needed for the crop. In general, such crops do not pay the cost of the fertilizer. It is not contended that there is no legitimate use for these various stimulating agents, for some of them have great value, and there is a proper place for them; but it is one of the problems of agriculture to determine their proper use and their improper use.

A common reply to the problem of restoring nitrogen to the soils has been to let the legumes do it. It is true that nitrogen can be added to soils by means of legume crops; but it is also true that legume plants prefer available soil nitrogen to air or bacterial nitrogen, and are likely to use the soil nitrogen before using the other source. If this 
is true, it looks like an enormous undertaking to restore to the soils the net loss of a million tons annually by the growth of legumes. It would seem a difficult matter even to maintain a nitrogen supply in soils having a large productive capacity, and well nigh impossible to build up a poor soil to a very high productive capacity. To pass the answer to legumes does not solve the problem of adequate nitrogen restoration. On a soil rich enough to give up sufficient nitrogen for a hundred-bushel crop of corn, how much nitrogen will be fixed by a four-ton crop of clover, when the nitrogen requirements are about the same for both crops? Or on fifty-bushel corn land, how much will be fixed when only two tons of clover are grown?

To keep any type of soil up to a high productiveness it is necessary to grow more or less of the deep-rooting legume crops for other purposes than the fixation of nitrogen; and it seems that the amount of legumes necessary for these other purposes is considerably less than the amount required to maintain a nitrogen supply. Will it be found profitable, then, to supplement legume nitrogen with artificially fixed nitrogen? If the promise to fix artificial nitrogen at about five cents per pound at the Muscle Shoals plant be realized, what effect will it have on the future of agriculture? Will the tendency be to replace legume nitrogen entirely, or will it still find a profitable use? With this cheap nitrogen, would the farmers be able to produce fixed carbon cheaply enough for it to be converted into motor fuel without economic ruin to the farming business?

\section{Maintaining Fertility Below the Plow Line}

A problem of great importance in the future will be to maintain the fertility in that part of the soil which lies below the plowed portion. The productiveness of the corn-belt soils has been due in great measure to the depth of their fertility; and especially in seasons of drouth is deep fertility a factor, because the deeper crop roots not only secure more food but are able to secure more moisture when needed. Plant food is constantly removed from the surface soil and below by ordinary cropping; it is moved upward and stored in the mature crop, which is taken from the land. The surface, or plowed soil, may be kept rich by plowing under organic matter in various forms and by adding other forms of plant food; but with the exception of limestone, this method does not materially improve the soil below the line of plowing. At Rothamsted where 15.7 tons of manure per acre were added annually for fifty years, the soil analyses at the beginning and the end of the period showed no material gain in any element of plant 
food below the plow line, but showed a loss of some elements.

While the general movement of plant food is upward, from the roots to the tops, in general cropping, there is a reversed movement from the tops to the roots in the case of deep-rooting perennial legume plants during the fall in preparation for winter maintenance and future growth. To what extent we can utilize this habit of certain plants will need investigation. We know that limestone will sink into the deep soil, in the form of hard water, from a supply maintained at the surface, but we need also to have active organic matter, nitrogen, and phosphorus added to the deeper soil if we want a deep root development on our grain plants. A single instance is not proof but it is indicative: A field on which has been grown a rotation of corn, oats, wheat, and clover (which was mostly alfalfa), with the late growth plowed under after translocation for winter had been made; on which limestone was maintained at the surface, and to which one ton of raw phosphate was applied during each rotation until five tons had been applied,- - showed by a single analysis, that there were about twenty tons more organic matter per acre and about twice as much phosphorus and sulfur in the soil below the plowed soil where treatment had been made as described above, than on the check halfacre which had had the same rotation but no mineral treatments.

\section{An Opportunity for the Plant Physiologist}

In the study of the plants themselves there is a wonderful opportunity for the plant physiologist to solve many of the problems now perplexing us; and when we come to the relations between the soil, with all its factors, and the plant, there is a field almost untrodden. It is conceded that sweet and acid reactions in animal bodies are factors in resisting diseases. Are plants also enabled by these different reactions to resist plant diseases, more or less? And what are the relations of the soil to these reactions? In plants the changing of sugars to starches and oils, and of oils and starches to sugars, is influenced by a number of factors, with temperature an apparent factor. What are the relations between the soil, climate, and latitude, and these factors? If quality of grains depends on maturity, and maturity depends on the change from sugars to starches and oils, we must know more about the factors which induce maturity, if we are to grow grains of high quality.

Many seeds and plants which prepare for a dormant period during the winter do not grow well again until some changes have taken place during the period of dormancy. Winter wheat, if sown in the 
growing season of spring does not form grain, nor does it produce well when sown in the fall if the winter be without cold weather. Spring wheat, when sown late, may make as much growth of straw as does that sown early but it does not produce as much grain in proportion as does the early sown. Hardy trees and shrubs do not grow so well in the spring after being kept from frost during the winter as they do after they have endured normal outside conditions. What are the problems involved in these changes, and is there any application to be made to any extent to such other crops as corn, oats, etc.?

Each grain or seed is a product of parental mating, and with plants the same laws prevail as in the mating of animals. We have studied the succession of visible characters under the laws supposed to govern; but has any attention been given to mating to secure those invisible characters-if they are invisible-on which depend such things as longevity, the inherent tendency to overcome adversity, to resist diseases, and to show strength in development in the face of adverse environment? Should we not study plants with reference to their vitativeness, if in doing so we may find some of the factors of immunity to diseases of many kinds? 


\section{BUSINESS ASPECTS OF FARMING}

\section{Charles A. Ewing, Decatur}

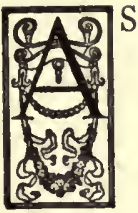

S A THEME for this occasion I have chosen-farming, a retrospect and prospect. And I will attempt a resumé of some of the problems arising in the leasing and operating of a number of typical corn-belt farms, and the conclusions arrived at concerning them; and then, tho not blest with the gift of prophecy, I will mention some things that seem to me not far ahead for all of us engaged in farming, whether as grain farmers or as stockmen. As the convictions or conclusions of others are the more readily evaluated by knowing on what experience they are based, and how they were arrived at, I will ask your indulgence for beginning at the beginning, and your pardon for being so much in the story.

A record yield on a small tract of from one to ten acres, or a single prize steer, produced under artificial conditions which do not, or cannot, and ofttimes should not, prevail in general farm practise, to my mind are illustrative of nothing in particular. If this tale be worth the telling, it is because the farms of which I shall speak have been operated not as a hobby but as a business. The endeavor has been to conserve and build up the fertility of the soil, provide a reasonably comfortable home for the tenant and his family, leave him a fair opportunity, and make a reasonable income on the investment.

In the operation of these farms the practises of husbandry as taught and promulgated by this College have in the main been adhered to. For more than half the time, a record of yields from each field has been kept, to determine the value of each crop to the enterprise. For several years on one of the larger farms, a labor record showing the man, horse, and machine hours expended on the various crops and in carrying on the work incident to the general operation of the farm, was kept. Some large yields have been attained on considerable acreages, but the thing sought after was to better the general average and to strengthen the weaker links in the chain, realizing that it is only the net return per acre made by a system of cropping that does not deplete the soil, which in the end tells the story of success or failure. 


\section{Farm Business Conditions During the Past Quarter of a Century}

It was in the fall of 1896 , now a quarter of a century ago, that I began to take an active interest in the operation and management of several thousand acres of central Illinois land, tho the responsibility for its management was not assumed until a few years later. The land did not lie in one body but in tracts ranging from forty acres up to more than a section. Let us consider for a moment the conditions existing in the farming business at that time, for they were worse then than now.

Some of you may recall a decline in the markets for farm produce that began about 1889 and lasted without very marked improvement until after 1897. During that time the barometer of farm business seemed wholly unable to find its way into the fair weather section of the chart. Corn sold for twelve to fifteen cents, and wheat around fifty cents; cattle went as low as a cent and a half, and hogs down to two and a half cents during that depression. It was during this time that the abandonment of the New England farms commenced, and hundreds of them were simply deserted and left to revert to the bramble and the briar. Alarmed at this condition, efforts were made to import foreigners to run the land, but without success, and even to this day that section has not fully recovered from the blight of that condition. Kansas, during these years, had a particularly trying time, aggravated by the cyclones, hot winds, grasshoppers, and other visitations of Providence and politics. It was then that the great movement from the country to the cities began, which continued almost unchecked for more than a decade. Then, as now, Congress was appealed to for legislative relief, but then, as will be the case now, the recovery was gradual. Now, however, some measures of relief are being advocated in behalf of the farmer that, in the end, will only aggravate instead of ameliorate his condition, among them being the issuing of the tax-exempt securities.

Certain it is that things were bad enough, and there was not much encouragement or incentive to remain on the farm. About everybody left who could, but a good many, then as now, were in much the same position as the fellow who had the bull by the tail. He couldn't let go. In 1897, some of the best land in the estate was offered for sale and brought from sixty-five to seventy dollars per acre; but even at those figures it was considered better to sell than to try to make it pay interest on that valuation. 
At the outset it was necessary for a period of several years to make an annual accounting in the probate court; and this was most fortunate, for it proved to be a lesson of the greatest value. It compelled keeping a careful record of the incomes and outgoes, and of profits and losses. The value of a performance record was soon recognized as being necessary for a study of the business, to determine what part of the operation was paying and what was not; and if not, why not. Systems already prepared were not available then, nor were there many to whom to turn for advice about it; so we worked out a system of our own to serve the purpose. For keeping a record of the cash transactions a regular double entry system was used. To keep a performance record, the farms were laid out in forty-acre fields; these were numbered, and each year the crop, its yield, value, and fertilizer applications, if any, were noted. A business-like method of accounting, of striking balances, of taking inventories, and of analysis of profit and loss is just as important in the handling of a farm as it is essential to the intelligent handling of any other business. The information made available by a good record of performance is the basis of intelligent farm management, and that is the basis of both safety and success. Any college of agriculture that does not include in its curriculum a thoro course of accounting suited to the needs of the farm business, and require every student to take it, is lacking one of the most important fundamentals. For if intelligent farm management isn't the main, ultimate objective of a college of agriculture, what is?

The need of definite information on many aspects of the business was keenly felt, so the acquisition of it began; but it came from so many sources in such different forms-books, bulletins, circulars, magazine articles, etc.-that soon it was impossible to find the things wanted. To obviate this difficulty, the material was all card-indexed according to subjects; so that, for example, the card for corn had a list of every article in the library pertaining to that subject. By this method, and almost for the asking, an extremely useful library was obtained.

It may be a strain on the credulity, but in those days both lumber and labor were comparatively cheap and money scarce. Buildings generally on farms under lease were of temporary construction. Frequently the landlord would buy the material and the tenant, with the help of a jack-of-all-trades from the nearest village, often called a hatchet-and-saw man, would build them. Not much consideration was given to their architecture, location, or arrangement, or the direc- 
tion of the prevailing summer breeze, with the result that it often required some determination to ignore the consciousness of the proximity of the barn lot to the dining room. Painting was rather expensive and therefore quite often omitted, which did not enhance the general appearance of things. The record soon revealed a rising tide of repairs that demanded attention.

As a result of our experience, gained in the course of years and at some expense, I have found it more satisfactory to lay out a building plan for the farmstead as a whole, governed by the location of those improvements already made and substantial enough to be retained, and by the size, topography and contemplated method of operation of the farm itself; and then to construct buildings of a better and more permanent character, with due regard to their relationship to each other as to conveniences and architecture. Such a plan has much to commend it, as it saves both regrets and expense and attains a more desirable result in the end, for one is assured when improvements are made from time to time that they will be in the right place; without such a plan an unsatisfactory arrangement is almost a certainty.

As to the drainage, most of the tile were lateral strings, of small size, emptying into small open ditches. Ofttimes, the tile were not adequate to take the water from the whole watershed to which they were servient, with the result that when the neighbor decided to drain his land, it was necessary to relay with a larger size or put in another extra string. So with the tile as with the buildings, it was finally deemed better to make a complete plan first. When considering the drainage of a farm, therefore, a complete survey of the entire watershed was made, and on the basis of the acreage and annual rainfall an estimate of the sizes of tile needed to do the work. Of course, maps of these surveys were made and filed for reference so that the location of the tile might be determined.

For years prior to 1896 and since, these farms have been operated as grain farms. Formerly, too large an acreage was planted to corn, and a little to oats; and while clover was intended as a part of the system, it so frequently failed as to be almost as much theory as practise. Wheat was then added to the rotation; which was changed as follows: the pasture averages about ten per cent of the farm, twofifths of the balance is put in corn, and one-fifth each to oats, wheat, and clover. Thus about half of the farm is in corn and wheat and the other half in oats, clover, and pasture. In 1905 applications of phosphate rock and, soon thereafter, of limestone, were begun and con- 
tinued until the freight rates and cost made them prohibitive. In almost every instance they have proven beneficial when properly applied, one striking exception being on a farm east of Maroa, Illinois, where the soil map, when it became available, disclosed the fact that the phosphate content was already adequate.

The record soon showed that the operation of the small farm of forty to eighty acres was top-heavy for both landlord and tenant, as the buildings, equipment and other upkeep furnished by the one, and the lack of opportunity to use to good advantage the horses, machinery, etc., supplied by the other, was a bad bargain both ways. The net returns per acre were too low to be a paying investment, and the tenant could not make a satisfactory return for his labor after paying the rent and his expenses. The small outlying tracts were then sold, as opportunity offered, and where small farms were contiguous they were consolidated; so that at present the farms range in size from two hundred and forty acres up to more than a section. It might be well to state here that only a small part of this land, less than a section, belongs to me; and my relation to it, therefore, has been that of a manager, tho a few times I have joined with the tenant in leasing and operating some of the larger farms for a time.

Over a period of years the half of the farm in corn and wheat has paid a satisfactory return; but the returns from the balance of the farm, taken separately, have not paid. So far, taken as a whole, the corn and wheat have made what in normal times would be considered a fair rate of interest on the inventoried values, as gradually increasing yields have been able to keep pace with increasing overhead charges; but it seems doubtful if this will continue to be the case.

Fifteen years ago this spring, I undertook the management of another considerable body of land, which differed in its previous history, having been operated as a stock farm. The stock was sold out, and for about seven years the land was operated as a grain farm. Since that time it has bcen operated on a system of stock and grain farming, a joint interest being reserved in the stock with the tenant, as follows: The crop rotation is similar to that already explained, and a number of sows and ewes are kept for breeding purposes, sufficient to pasture the grass land and about three-fourths of the clover. About half of the sows are re-bred for fall litters; in the late summer or early fall a few stock cattle are bought, and thus a home market is provided for the roughage. These farms are fenced in forty-acre fields, hog tight, and provided with a water system so that any field can be pastured off. 
When properly equipped, and with a tenant who is competent to handle stock, this system is, to my mind, the best. Pasturing the clover is not only a more profitable way to market it and makes a better return on the pasture than the prevailing cash rental, but it also takes off one of the peak loads of the work, namely, that of making hay; and lightens another, that of harvesting corn by hogging some of it off. It is good for the land, distributes much of the manure where wanted, brings up the returns on the part of the farm that most needs it, and has fewer chances for failure and more chances for success than either a strictly grain or a strictly stock method.

An investigation was made a few years ago under the direction of the University, to ascertain the number of acres operated per horse, on the typical farms of the state; the reports ranged from seventeen to twenty-eight acres. The same year, on one of our larger farms operated as a stock and grain farm we were doing pretty well with one horse to forty acres.

In seeking a substitute for oats, several things have been tried, with varying success, among them cowpeas, soybeans, buckwheat, and barley. Out of six comparative seedings of oats and barley, two years the returns were about equal and four years the barley made decidedly the better showing.

\section{Tenant Relations}

As to tenants, it has always been a custom to retain a good man as long as he is in sympathy with better farming practises; and some long relationships of that character have existed, several having extended over thirty years, and one tenant has not far to go until he reaches his fortieth year on one of these farms. These are unusually long periods and except for divers reasons these parties would have earned and retired to a farm of their own; for it has been my pleasure to see a number start from the bottom and accomplish this very thing. In farming as in other lines, however, not all men can accumulate, or circumstance may circumvent them. In spite of all that has been said to the contrary, and there has been considerable agitation against landlords, some of it emanating from sources that should know better, a good farm offered on a fair lease affords to many a young man with a very limited amount of capital an opportunity to go into business for himself under more favorable conditions than are found in almost any other line of endeavor.

Right here, however, is a question that will stand more study. What sized farm should a tenant rent? It is not profitable for the 
landlord to rent an improved forty-acre farm; neither it is profitable for the tenant; and I do not hesitate to say that with the prevailing high cost of operation, a farm of eighty acres offers but a scant opportunity unless it is used for some intensive work, such as trucking, or fruit or poultry raising. I wonder how many farms there are in this state so small or so poor that they hold no reasonable chance of success. It is the men on these farms that are most easily capsized by any adverse wind.

During the period of my experience I have had charge of considerable land in other localities; namely, Indiana, Missouri, Mississippi, and Tennessee; and the disadvantage of being at such a distance that supervision was difficult and often not as thoro as it should be, leads to the conclusion that such distant holdings are not desirable.

\section{What of the Future?}

In closing this review of the past, I am conscious that my efforts have been almost wholly directed at one phase of the business of farming, viz., that of production. I am conscious that the margins of profit, never large as profits are figured in most businesses, have been crowded down to the danger point, if still visible at all; that the trend of taxes has been upward, with alarming rapidity; and that the overhead costs of machinery, labor, material, and repairs have increased very greatly. I find myself wondering how long we farmers can continue to ignore these other sides of our business, and go on producing; how long can we play the game by such a rule and hold a winning hand?

What then of the future? This is oft best foretold in the light of a knowledge of the past, and there comes to my mind this saying:

"Ill fares the land, to hastening ills a prey,

Where wealth accumulates, and farms decay."

We are told that when darkness settled over Egypt and she lost her place among the great nations of the earth, three per cent of her population owned ninety-seven per cent of her wealth. When Babylon went down, two per cent of her population owned all the wealth. When Persia bowed her head, one per cent of her population owned all the land. When the great empire of Rome fell, eighteen hundred men owned and controlled all the then known world.

What of our own country? In 1850 our capitalists owned thirty-seven per cent of the nation's wealth. In 1870 , only twenty 
years later, they owned sixty-three per cent. In 1920, we find less than five per cent of our population listed as paying any income tax whatever. Hence, it is reasonable to assume that the wealth of this country is concentrated in the hands of some part of that five per cent of our population. This affords much food for thought, if we will only stop and think. How, in this fair land of ours, rich in every resource, under a government of, by, and for the people, could such a state of things come to pass? Interwoven throughout the warp and woof of the political and industrial history of the states and the nation since the reconstruction period following the Civil War, on down to the present day, may be found most of the reasons for this condition. They are already matters of record and too voluminous to relate here. But most of them will be found to be in contravention of some of the fundamental ideals of our Government. We farmers, however, are not without blame in the matter; our ears have been deaf to the warning long since uttered by one of our leading statesmen, "The price of liberty is eternal vigilance." We have followed the pied pipers of party politics, not knowing or recking where they led, and too often have cast our ballots for measures adverse to our interests. We have for the most part ignored every phase of our own business, save but one, and that one circumscribed by the farm fence; namely, production. Produce, produce, produce, has been the beginning and the end of our thought and teachings, taking whatever was offered at the market, paying whatever was asked for what we needed to buy; and I assert that such a method has in it the germs of an economic slavery, just as real and just as dangerous as the serfdom of Russia or the Sepoy slavery of India. It is said that the Danish farmer, through his marketing organizations, is able to retain eighty to ninety per cent of the value of his produce, and that the American farmer, through the lack of such effective associations, retains about ten to twenty per cent of their value. A bushel of wheat sells for about one dollar, while a bushel of puffed wheat sells for about thirty dollars.

The time is at hand now when the other sides of this great enterprise of farming must have their just share of recognition at the hands of the farmers, and we must relieve the business of the handicaps that have been put upon it. We must take a hand in shaping and directing the course of our governments, both state and national, in some measure more nearly commensurate with our support of them, and see to it that agriculture has a fair chance. The questions of transportation by road, rail, and water vitally concern farmers and their business, as do also distribution, domestic and foreign markets 
and marketing, foreign trade, foreign exchange, credits, and finances. These are some of the matters which must have consideration, not only separately but relatively, and if farmers are to be heard on these matters they must affiliate with organizations that will represent them. The organization of the Farm Bureau, county, state and national, is a step in the right direction; but mark this well, the doctrine of opportunism will neither carry very far, nor long endure, nor will it succeed in rallying to its support other kindred organizations. The ills that beset us are not so difficult that they can't be cured, but we must understand them. The Farm Bureaus must carefully diagnose our case and formulate a policy of treatment, not only to make known to its members and others the principles for which it stands and the goal it strives to reach, but to mark its own progress and avoid meandering from its course. If this be done; if a plan be conceived in wisdom, not aimed to subvert other lines of enterprise, but determined to remove the handicaps under which agriculture, our greatest art and our master science, has so long labored; and if the farmers and stockmen of the country will catch the vision of a united cooperative movement for their own and their country's best interest and consecrate themselves to its support, we may with confidence turn our faces towards the dawn of a brighter day.

At this time and at this place we may ask, What part in this program will be taken by the College of Agriculture? Let me remind you that these times of adversity are not without their silver lining; they are times of real progress. It was after the hard experiences of the period from 1889 to 1897 that the renaissance of agricultural education began, the growth, development, and progress of which have been without a parallel anywhere, in any field of learning in the world. It was then that with but nineteen students regularly enrolled in the agricultural course, an appropriation was asked of the state, and given by it, to erect a building to be devoted to the study of agriculture, which should be the largest yet built for that purpose. They were men of vision who asked it and worked for it, as were also they who gave it. Let us not forget, however, that the world moves; and among other things come, faster than we realize but never fast enough, the changes in our curricula. Each generation sets up a new list of requirements and each is deemed necessary and essential; and perhaps at the time and under the conditions prevailing some of them are. Were I to pass a general criticism on the schooling of today, it would be this, and it applies all the way from our grade schools on up: that in fitting a student for a particular line of work 
the emphasis has been too much on the work and not enough on the student as a man and a future citizen; too much stress on material success, too little on his obligations to society and the state; in short, too much on selfish aims and not enough on service. For it always has been, still is, and will continue to be one of the verities of life, that it matters not if a man gain the whole world, if he be lacking in some of these attributes of character he fails of success. It is not by what we have or acquire in a material way, nor yet by our intellectual attainments, but by what manner of men we are, that we be judged. And in this country of ours, under this form of government, which holds so much of promise for mankind, but is as yet in the experimental stage, our ideals and character as a people are vital.

In retrospect, I see the College of Agriculture, like the farmer, with its attention focused mainly and largely on production. In prospect, I see it with a wider outlook on the business, grappling with the other sides of farming, sifting them to the bottom, winnowing out their underlying principles and instilling them into the minds of the young men who come here to be informed on this subject, and from whose ranks we shall draw leaders, well trained and grounded in these principles, to carry forward the cause of agriculture, serve it, and ably represent it. It is not enough for the state to teach a man how to produce; it must teach him how to protect what he produces.

Twenty years ago when the then new Agricultural Building was completed, it was dedicated to "Agriculture, The Master Science"; and across its front it bears this inscription, "The wealth of Illinois is in her soils and her safety lies in their intelligent development." At that time, nothing could have been more fitting or appropriate, and the development of the scientific side of agriculture has borne fruits of inestimable value. This work, of course, must go on; but were it for me to say what should be the dedication of the College for the next twenty years, I should say "Agriculture, our Greatest Business," and I would paraphrase the inscription the present building bears, as follows: "The wealth of Illinois is in her young men and women, and her safety lies in their intelligent development."

To the business of agriculture then and the men who are going to transact it and represent it, would I direct your attention. Instead of doubting if this prospect can be realized, I am full of hope that it will be and with confidence await what lies ahead. 


\section{THE FARM BUREAU}

\section{E. T. Robbins, Farm Adviser, DeWitt County}

EN YEARS of Farm Bureau work in Illinois are already a matter of history, and the record reveals significant changes in aims and methods. Begun primarily to extend agricultural education among busy farmers, the Farm Bureau's major efforts are now directed in business channels. This has been a logical and natural change. The Farmers' Institute, the Short Course and the agricultural shows were already covering much of the agricultural extension field. As soon as a Farm Bureau converted a man to the use of limestone, for example, the immediate question was where, when, and how to buy it. When a Farm Bureau assisted a man to purchase the limestone, he was actually initiated into its use; otherwise he seldom made the start. It was just so with rock phosphate, alfalfa, sweet clover, pasture mixtures, soybeans, improved varieties of grain, and pedigreed live stock. Then followed the necessity of finding a market for any resulting product, such as sweet clover seed, soybeans, Percherons, or Shorthorns, whose marketing channels were not already well beaten paths. The Farm Bureau exchange list quickly established itself as a regular and valuable feature of the periodical communications sent to the members. County association live-stock sales became a necessity.

These business features of the work have tied the membership more closely together than purely educational projects could do. Men will flock to a stock show, a horse race, or even a street dog fight; they will attend a meeting where dollars tell of business achievement. Action attracts where mere mental stimulus is ineffective. But when gathered for the consideration of business problems of local, state, or national scope, farmers are ready to grasp incidentally new ideas for improving farm production. Agricultural teaching has found its most attentive farm audiences at business meetings.

\section{The Farm Bureau Built from the Ground Up}

The Farm Bureau is unique among farm organizations because it is founded upon individual paid memberships, secured through the initiative of natural local leaders. It is built from the ground up, not from the top down. The overhead organizations of state and national scope are the outgrowth of these county units, developed by them to concentrate the influence of the thousands and millions of in- 
dividual farmers. There is nothing dominating or paternal about the Illinois Agricultural Association, for instance. On the other hand, it is the mouthpiece and the active servant of the individual farmer and draws its authority from him through the county Farm Bureau. Its special work is to conduct for the individual member the legislative, transportation, and marketing projects which require combined power.

Rational leadership is an absolute essential in Farm Bureau organizations. Safe, sane, conservative men are the best guides to steady the course of action suggested by many enthusiastic minds. The directors of Farm Bureaus and of their state and national associations have developed their plans with commendable care and patient deliberation. The best proof of this is the success of every important project which has already had time for development. Of course, paid executives are necessary so as to be always on the job, to carry the plans of the directors to successful conclusion, and, incidentally, to suggest new projects and plans. So far, there has been great responsibility placed upon the farm advisers and upon the state and national paid officials. We are working a comparatively new field. It is much more difficult to work out a new and practical plan of marketing, for instance, than it will be to carry it on twenty years hence, after its details have been fully tested, improved, and established.

\section{A Diffusion of Responsibility}

In the operation of county Farm Bureaus the present tendency favors a rather extended diffusion of responsibility. Township and community units, with local chairmen and committees, serve the general wishes and requirements of the members. Live-stock shipping associations, dairy, and fruit organizations, and the already established cooperative grain companies, with paid managers, are handling the initial process of cooperative marketing of farm products. Their work is supplemented in a special field by the county breeders' associations, with their combined advertising and consignment sales; thereby virtually guaranteeing to the young breeder a market for his purebred animals. That alone has marvelously increased the ranks of live-stock breeders in recent years. In Tazewell county, in the years, twentyfour young men were added to the list of Percheron breeders because of the Tazewell County Percheron Association.

In thus enlisting the services of many members of a community in its development projects and marketing problems, the Farm Bureau work derives the benefit of suggestion and advice from minds of var- 
ious types and from a multiplicity of viewpoints. Valuable ideas have thus been developed. The chances of failure have also been reduced. "In a multitude of counselors there is safety." Then, too division of responsibility among many members seems to be the very best way to develop strong local leaders, men who will become the logical ones to shoulder the cares of the county, state, and national federations.

The local units are sure to be very important factors in the future life of the Farm Bureau. It is through them that membership enrolment, the collection of dues, and the maintenance of morale can be handled most surely and economically. The local leaders and committees maintain an intimate and almost daily contact with individual members, which it is impossible to secure in any other way. The local committeemen are absolutely necessary in conducting membership campaigns. In fact if they should handle the details of this work with little outside assistance, it would probably be the ideal condition.

Through the local organizations the special needs of the community, such as chinch bug control or any other local project, can best be ascertained and met. The burning of chinch bugs, for example, is necessarily a local project, requiring the cooperation of every farmer in the territory. It cannot succeed in any other way. Any such efforts which enlist the attention of a large share of the local residents serve to develop and strengthen the spirit of cooperation. Fortunately this spirit is already a factor in community life, as displayed in exchange of labor in threshing and shelling. It is only necessary to extend this fellowship into the range of more comprehensive enterprises.

Local units also serve to keep the weak members in line. There is much opposition to Farm Bureau work by those business men who fear that eventually it may cut into their profits in one way or another. By organized propaganda and individual knocking, they have attempted to discredit cooperative work and discourage members of farmers' organizations. It is difficult to conceive the state of mind of anyone who would be prejudiced by such disparaging talk from an outsider, but the actual fact is that Farm Bureau members here and there have become dissatisfied as a result of the so-called friendly tips of their business enemies. Continual boosting by well-informed and broad-minded local leaders is necessary in order effectually to counteract the poison which is thus steadily injected into the veins of farmers' organizations. Little progress can be made when half of us are push- 
ing forward and the other half pushing backward. The full measure of success by the Farm Bureaus can be attained only when the great majority of farmers are enthusiastic members.

\section{Standardizing Farm Practises}

The Farm Bureaus are gradually standardizing farm practise in various localities. Hitherto the principal accomplishment in this line has been in the introduction of farm implements by dealers. The result has been a more rapid agricultural advancement in the use of improved machinery than in the adoption of pedigreed live stock, or high yielding varieties of crops, or the extension of soil conservation methods. It is up to the Farm Bureaus to convert their members to the use of those improved methods which are not pushed by salesmen; and they will do it more conservatively and more satisfactorily. The same crop rotations or live-stock interests which make money for one farmer should also prove profitable for his neighbor under similar circumstances. Local demonstrations and community meetings serve, to convince skeptical neighbors that their methods can be improved. One farmer in DeWitt county told me the other day that he never saw a soybean until he went to a farm demonstration meeting two miles from his home, where the crop had been raised continuously for twelve years.

Some real persuasion is necessary to deflect a man from his chosen system of farming, inherited perhaps from his father. The business side of the question is what convinces; and the Farm Bureau can present the problem and its solution in dollars and cents under home conditions. In the future we may well expect more progress to be made through farm management studies based on actual farm accounts, than by any other means. We know that under present depressing conditions many farmers are making nothing on their investment and are getting nothing for their own work, while some of their neighbors are making five per cent and in addition some hundreds of dollars annually to pay for their own time. Such disparity has appeared every year since farm management studies were begun. The Farm Bureau is peculiarly and almost exclusively situated so as to turn such figures to practical account in the community.

As farmers become accustomed to calling at the county Farm Bureau office to confer about their problems, and form the habit generally of attending local business and demonstration meetings, it will be possible for one farm adviser to serve a larger number of members than has been the case during these pioneer years. There will be less 
farm visiting and more conferences with groups of members.' As time goes on, we shall doubtless develop a well defined system for maintaining intact the county organization and local units, which are the absolutely necessary foundation for effective state and national organizations for legislative and marketing purposes. That will simplify the work; but initiative, resourcefulness, originality, determination and a thoro acquaintance with farm problems will still be required of farm advisers. Probably the principal reason for the prominence of Illinois in Farm Bureau affairs is that the men for this work have been rigidly selected and suitably paid and have been expected to secure commensurate results.

\section{Cooperative Marketing of Farm Products}

The marketing of farm products is certain to become generally cooperative. We are making rapid progress in this project because of the concerted efforts of county, state, and national associations all along the line. Local shipping associations affiliated with the Farm Bureaus are already an assured success because of their demonstrated economy in consigning live stock to market. Their membership and shipments grow month by month. The cooperative commission companies so far established at the markets leave no cause to doubt that they will satisfactorily, economically, and permanently bridge the gap between live-stock producer and manufacturer. The wool pool has weathered a stormy early life and emerged into a smoothly functioning and efficient marketing partner of the Farm Bureau. The I. A. A. potato pool last fall distributed through the Farm Bureaus the best potatoes ever bought by Illinois farmers and at prices which dealers could not meet. The local cooperative grain companies are gaining in number and prestige through persistent boosting by Farm Bureaus. The next great movement, already well advanced, is the founding of the U. S. Grain Growers, Inc., whose local footing and financial backing are founded upon the county Farm Bureaus. The successful development of this project, in the face of the most powerfully financed opposing propaganda ever confronting American farmers, will surely be accomplished, and that of itself will be worth to the farmers of America all the costs of all the Farm Bureau work for all time. This immense gain will not be secured through domination of markets but through small economies and various small items of profits incident to the transfer of grain from the producer to the consumer. 
The Farm Bureaus have led farmers into greater progress in the last ten years than in the thirty years preceding. While the cost has reached a considerable total, it is small as apportioned to each member and as measured in results. Every Farm Bureau member gets full returns on his investment, even if he makes no effort to do so. And yet it is our duty to make the work both economical and efficient to the greatest degree. Farm Bureau directors should not be mere enthusiasts; they should be farmers who succeed in the financial management of their own farms, who appreciate values and who can fairly calculate returns on an investment. We are now passing through the most expensive period of Farm Bureau work, just at the time when farm finances are at low ebb. In pioneering these marketing efforts, for example, we cannot accurately forecast the returns on all the outlay in cash and effort. Some expenditures will eventually prove to have been unproductive, and this adds to the final cost. It is much more expensive to invent and try out new plans than to execute old and established systems; but the initial steps must somehow be taken or no revision of agricultural methods will be effected. As fast as these new systems are developed, it will be possible to lop off introductory features, and thereby save much expense. Delegating a large measure of responsibility to the local marketing units is calculated to effect economy as well as to stimulate loyalty, and this principle again coincides with the prominence we attach to the local units in the Farm Bureau. Overhead control should not be sufficient to dominate, but merely to coordinate systematically the work of local marketing agencies. So far as we have gone in these projects, these principles have been followed. Even the centralization provided in the U. S. Grain Growers, Inc., extends only to the point of concentrating sales into sufficient volume; and full local representation is provided in the management.

\section{Publicity of Subject Matter and of Aims}

Publicity is a necessary feature of Farm Bureau work. Periodical communications from the county office are needed by individual members to keep them fully informed concerning the business and educational features of the work, not only within the county but in the state and nation at large. They should have in concrete form such information as can be useful in improving their individual businesses and the cooperative enterprises in which they are engaged. This can be shaped in an attractive form to fit local conditions and to anticipate the inquiries which would naturally arise from time to time. The 
county publication or circular letter which is sent to all of the members, not only supplies the information and encouragement which every individual should have, but it furnishes material for the active member to use in boosting the Farm Bureau among his indifferent associates. The more any member knows about the aims, methods, and accomplishments of his organization, the greater his loyalty will be and the more he will profit from it. Greater knowledge will also fortify him against the insidious influence of propaganda from dealers who oppose him.

The boys' and girls' clubs carry this publicity idea into the future. They train the next generation of farmers to appreciate the vast improvement which is possible in general agricultural practise. Club work cultivates a high appreciation of fellowship and mutual interest in the projects and problems of the farm. The young folks learn to keep cost accounts, which are certain to stimulate a desire for economical and profitable marketing. The club members now will undoubtedly become the Farm Bureau leaders a few years hence. Their present-day interest and enthusiasm are also sure to spread to their parents and their associates, so that the benefit of club work is far-reaching.

Publicity in the local and county newspapers is also necessary in order to give the general public a fair understanding of the purposes of the farmers' organizations. There are many who profess to believe that a farmer's sole duty to himself and the nation is to produce, to take up his position between the corn rows and in the feed lot and limit his operations to the confines of his line fences. The general public has been imposed upon so much in the past by various trade monopolies and trusts that there is natural suspicion of any new marketing venture and opposing interests make the most of this prejudice in their propaganda. Fortunately, there is no occult objective for farmers' cooperative organizations. Efficient and economical marketing is the aim, and that cannot injure the consumer. It will hurt only those who now profit unduly at the expense of both producer and consumer. Consequently, it is best for all concerned to give general publicity to the purposes for which farmers are organized. An honestly enlightened consuming public will welcome and assist their advance. Those whose present business may be encroached upon may then see the light and readjust their operations along lines of greater service to the community. 


\section{FUTURE WORK}

There will always be plenty of work for the Farm Bureaus to do. Constantly shifting production and trade problems the world over are sure to necessitate readjustments in rotations, in live-stock breeding and feeding, and in marketing operations from time to time; and the Farm Bureau is the logical means of putting the necessary changes promptly into effect. A feature just now is a sensible reduction in corn production by replacing part of the acreage with soil-improving legume crops. Only concerted local agitation and persuasion will get us anywhere with this proposition. If we had been sufficiently organized to cut down the corn acreage a year ago when the need was plainly apparent and was strongly urged, we could have averted a corn-belt catastrophe. We must depend upon the Farm Bureaus to guide production along necessary and profitable channels, without the disastrous overproduction and underproduction at times which have featured our agricultural history. When our lands have been farmed longer there will also be greater attention demanded by the fertility question. New marketing problems are sure to arise, and always there will be the demand for developing and introducing those systems of farm management which best conform to changing economic conditions. 


\section{THE ILLINOIS AGRICULTURAL ASSOCIATION}

\section{O. Thompson, Secretary, Chicago}

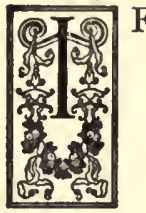

F I were to figure out what seems to me to be the start of the Illinois Agricultural Association, so far as I can get it from the record today, I would go back to the graduating class of '76. If I were a philosopher, I would sit down and meditate upon the question as to whether the state of Illinois could not well have built an institutionan educational institution-back in those years, for the sole purpose of graduating one student in the year of '76 who would have upon the agriculture of the state of Illinois the influence that that one graduate has had. I believe the investment in the whole institution would have been worth while, just for that one thing.

Seven years ago in this building, for which the Dean of Agriculture and the Farmers' Institute worked so hard, there met a group of Farm Bureau officers who had been coming here for a few years with the farm advisers in order to see if there were not a few things which they had in common which they might discuss, and perhaps form a sort of loose organization. Following that a meeting was held at Ottawa. After much discussion and argument, the organization was formed. I think the greatest amount of debate was as to whether it should be called the Illinois Agricultural Association or the Illinois Agricultural and Live Stock Association. Mr. Herman Danforth was elected president. He was president of the Farm Bureau in Tazewell county; and Mr. E. T. Robbins, the farm adviser in that county, was elected secretary of the organization. Some years later Mr. John Kirkton, of the Livingston County Farm Bureau, was elected president and Mr. R. C. Bishop, farm adviser in that county, was elected secretary. Some time later, Mr. Kirkton continuing in office, Mr. Leonard, who was president of the Woodford County Farm Bureau, was elected secretary; and it was during that time, and immediately after the war period, that the Association undertook its largest program of work. The important thing, to my mind, that happened was that the Association, instead of continuing on as an association of groups of farmers, was changed to be an association of individual farmer members. At that time, Mr. Harvey Sconce was elected president, and I was hired as secretary and since that time have been trying to do everything except to get the fellows down East to come out here and eat their pork chops out in the feed lots. 
I am always glad to give suggestions as to what we should try to do. I gave to most of you, a week ago or two weeks ago, a resumé of the work of the Association during the past year-which was really a resumé of three years,- -and I think I shall not take time now to go into that. In my mind the work of the Association is shaping itself into some pretty definite things; and I can see in the future, at least a little way into the future, that if it is to meet the situation as it should be met there must be some shifts-some changes in the form of the administration of the Association, some shifts in the lines of work pursued, and a very clear-cut, well-defined policy of work arrived at during the coming year, so that stakes for the future can be set up based on right conclusions.

I believe that there will be one department of cooperative marketing in the Association. Now that will not all happen this year; but it is going to happen some time in the future, when some of this preliminary stuff has been worked out. And I know as well as I know that, that there will be a department of finance, taking in the questions of revenue, taxation, farm financing, and farm credit; these are the subjects that such a department is going to handle, study and put itself in position to work on. It will have to follow a pretty definite policy; it must know pretty definitely where it is going, and then it must work to get there. Then there will be a department of transportation. The immediate question before the house is freight rates, but that is the least of our questions. Under the head of transportation, we have a road question. The farmer has a tremendous road question, and under the same head he has the waterway question. Transportation in the future is going to mean, in this organization, more than a reduction of freight rates. Then there is going to be a general legislative department, which will be tied up perhaps with the legal department, perhaps not; I do not know whether the farmers want the law tied up with the legislative department or not. But questions of law and legislation will be grouped fairly close together. Then there will be, of course, the general administrative department of the Association.

Now, I do not claim to be a prophet, but I am willing to prophesy on this particular thing as coming true in the life of the Association. It must come if the Association is going to serve its place as one of the several factors in the agricultural life of the state of Illinois. If the Association, as a volunteer association of farmers of the state, is going to make the third point in the triangle, with the State College of Agriculture and Experiment Station, and the State Department 
of Agriculture,-if it is to take its place there, these things are going to have to come true. Furthermore, in the future, the farmers of the state of Illinois are going to need to call more and more to service in that organization men who know the business aspects of farming, for these are business questions the proper answers to which determine the answer to the question that is in the mind of more than one of my pals, "Can I afford to farm? Can I take a chance on farming?" Until that question can be answered positively, in the affirmative, the young man hasn't much business thinking about it.

What has been borne in on me in fifteen or seventeen years spent around among the farm people of the states of Indiana, Illinois, and Wisconsin is that a "punkin," no matter how big it is nor how good looking it is, isn't any good as a farm product unless it will pay a profit. You can grow a better animal or a better ear of corn; and you can inspire a man to do that; but unless you can teach. him how to get his money out of it and live, you haven't taught him much.

As I see the job of the I. A. A. in the future, it is to take its place as the third point of that triangle-the University and Experiment Station, the State Department of Agriculture, and here a volunteer association of farmers in the I. A. A. It is going to have a glorious part to play in its time, almost as glorious as the pioneer in the field-that other great institution in this state, the Farmers' Institute-played in its time. 


\section{AN INTERNATIONAL CROP REPORTING SERVICE}

\section{HARVEY J. SCONCE, United States Delegate to the International Institute of Agriculture at Rome, Sidell}

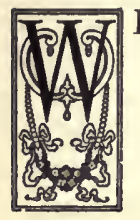

HEN the American delegation, consisting of three delegates, attended the International Institute of Agriculture at Rome in November, 1920, they decided that the paramount issue of this nation was a better crop-reporting service for the world, and their united efforts were extended in this direction.

At the meeting of the General Assembly, America was honored and our crop-reporting service was duly recognized as the best of the entire world, to the extent that Mr. L. M. Estebrook, one of the delegates and Chief of the Bureau of Crop Estimates of the Department of Agriculture at Washington, was chosen chairman of the Second Commission which had to do with crop estimates and statistics.

\section{The Need of Accurate, Complete, and Timely Statistics}

I was also placed on this commission with Mr. Estebrook; and in an address to the General Assembly I tried to bring before the delegates of the fifty-six nations represented, the attitude of America relative to a world crop-reporting service, and to show how essential it was that each country should have a reliable system of statistics that would be accurate and timely. I outlined the present condition to them, showing that only a few countries had any system that was dependable, while other nations had little or no service whatever; also that some of the countries who were attempting to report crop statistics did so at such a late date that the information was worthless so far as the markets of the world were concerned. I attempted to show further that the systems of different countries varied in detail so much that by the time the reports were received, the information translated, and the figures of the foreign nation converted into the units of our nation, so much time had elapsed that the resulting information was without value. I urged that a standard system be adopted, and that this service should embrace a complete agricultural census: statistics and estimates of acreage; yields per acre and total production of all crops grown; numbers of different classes, sexes, ages, and breeds of all live stock; crop and live-stock forecasting; farm and market prices; crop, live-stock and land values; popula- 
tion and per capita consumption; imports and exports; stocks on hand; surpluses and deficits; supply and demand; trends of production, consumption, and prices.

It was urged that this information, to be of the greatest value to the adhering nations must be timely, dependable, and unbiased, in order that it might be used with confidence as a guide to production and marketing programs. Much information regarding foreign agriculture is available in past and current literature, official bulletins and reports, and unofficial trade papers. However, a great deal is not available in any form and the information that is available is mostly historical, incomplete, and fragmentary, and neither systematically arranged nor promptly accessible. In fact, it is information that has passed its greatest usefulness and really has no bearing on present conditions.

At present this nation is receiving agricultural reports and bulletins from foreign nations, but the crop reporters are dilatory in getting their reports ready and the printers are also dilatory in getting their part of the work done. Another delay is caused in mailing and transmitting the bulletins, while a further delay is caused by their translation; so that, by the time it is ready for the farmer, the grain merchant and the business man, the information is out of date and worthless.

Some of the foreign nations have never taken an agricultural census, and others have done so only at infrequent intervals. Information of this kind should be collected at stated intervals and in a standardized manner.

The International Institute of Agriculture at Rome, organized in accordance with the international treaty promulgated in 1908, furnishes, through its monthly and annual bulletins, information relating to crop reports, agricultural statistics, agricultural technic, diseases of plants, and agricultural economics which is of great value. However, the reports of the Institute are lacking in completeness; many important crops are not covered by the reports. They also lack timeliness, because the Institute has no organization and no representatives in foreign countries for collecting data, but in accordance with the international treaty, must depend upon data transmitted to it by the adhering governments.

As the adhering governments are without proper organizations and methods for collecting these data, the reports of the Institute can be no better with respect to accuracy, completeness, and timeliness than the original reports transmitted by the adhering governments. 


\section{A Standard System of Crop Reporting}

After bringing these facts before the Institute, we introduced a resolution which was afterward adopted, providing that each adhering nation should adopt in the near future a standard system of crop reporting; that all the information should be telegraphically communicated to the Institute not later than the tenth of each month; and that bulletins should be compiled and distributed to all the adhering nations not later than the twelfth of each month. Each nation agreed that it would endeavor to establish a standard system as soon as it was possible to get trained experts for the work.

\section{Agricultural Attachés for Foreign Embassies}

To further facilitate this work of crop reporting, I introduced a resolution which was adopted, providing that agricultural attachés should be placed in the embassies of the foreign nations to assist the adhering nations in gathering the agricultural statistics and in bringing the system of crop reporting to a greater state of efficiency; these attachés to act also as agents for agricultural associations of the nations represented.

It has been suggested that the American consuls in the various nations could assist in transmitting crop statistics, and there has been a law on the statute books for a quarter of a century requiring the American consuls to furnish crop reports to the Secretary of Agriculture through the Secretary of State, but so far this law has been a dead letter. The fact of the matter is that the consuls are appointed without any regard to their knowledge of agriculture and are not trained in agricultural work whatever; therefore, any information they might gather is taken from newspapers, trade journals, and other sources that are not dependable. They lack the qualifications necessary to be able to furnish an intelligent report on the agricultural conditions of a nation because they are unable to understand clearly what is wanted by the Department of Agriculture or to appreciate the relative significance and value of information which is accessible to them.

The commercial attachés of the Department of Commerce are another possible source of information. However, in the past they have rendered no service of value to the Department of Agriculture and very little if any to American agriculture. Their primary function is to obtain information useful to American business men in promoting trade in American manufactures; which in itself is enough 
to occupy their entire time, thought, and energy. Their training is along other lines than agriculture, and in fact the commercial attachés who were interviewed in the foreign nations by the delegates to the Institute appeared to have very little knowledge of either American or foreign agriculture. Without exception, they appeared to be wholly ignorant of the fact that the farmers of the United States produced in 1920 and 1921 tremendous surpluses for which there was no adequate market and which were sold at ruinously low prices, causing the loss of millions of dollars and reducing the purchasing power of farmers approximately one-third to one-half; which reacted disastrously upon business in other industries and caused the shutting down of factories resulting in widespread unemployment.

At the Institute and before the Committee on Foreign Relations when we returned from Rome, the American delegation strongly urged the placing of agricultural attachés in foreign nations, these attachés to be to American agriculture what the commercial attachés are to American commerce and industry. As the result of the arguments before the Committee on Foreign Relations, a small appropriation was made for this work, and the work has been started in a small way. At present the Department of Agriculture has stationed Mr. Foley in London and Mr. Bullock in Buenos Aires, and they are rendering most efficient service. For instance, this past fall when the Department desired prompt information as to the newly sown acreage of wheat in Argentine, the Department of Commerce was notified to get the official figures as soon as available and cable them. At the same time the same question was asked Mr. Bullock, who cabled the desired figures within forty-eight hours. A week later the Department of Commerce wrote that the Argentine figures would not be available for another month. This shows the value of having a man on the spot to render service when it is needed.

Last June three cotton specialists were sent to the World Cotton Convention at Liverpool and the International Chamber of Commerce meeting at London. Two of these men remained abroad long enough to visit the principal cotton ports and cotton milling centers in Europe, as well as the Nile Valley and Palestine. They obtained information of much value, especially with respect to marketing prospects and the possibilities of expanding trade in cotton in Poland. In the late summer a specialist in the meat packing trade, Mr. E. C. Squire, was sent to Europe. He has been collecting and forwarding valuable data with respect to stocks of dairy and meat products on hand, demand, prices, and trade conditions. 
In October Professor G. F. Warren of Cornell and Mr. W. F. Callander of the Bureau of Markets were sent to Europe to study sources of information, as well as public and private statistical information on economic conditions, to arrange with the various officials for the prompt interchange of crop reports by mail and cable, and to formulate a systematic plan for the regular flow of agricultural statistics and economic data to the Department of Agriculture to supplement the information of the International Institute. Both Professor Warren and Mr. Callander report that the commercial attachés are not qualified to obtain information on agriculture because of their limited commercial viewpoint.

In November Mr. Michaels, formerly with the Food Administration in Russia, was employed and sent to Southeastern Europe to collect and report upon agricultural conditions. During the past summer arrangements have been made to have the commercial attachés and American consuls in foreign countries supply certain kinds of information under a set of instructions prepared by the Bureau of Markets.

At present the program of the Department of Agriculture is to utilize all existing agencies, such as the International Institute of Agriculture, the commercial attachés and the consul officers of the State Department so far as practicable, and to supplement these agencies with agricultural attaches in the principal countries. The object is to collect information concerning stocks on hand; consumption requirements; surpluses and deficits; economic situations affecting production, consumption and purchasing power; farm prices and agricultural credit; cooperation; the presence of plant and animal diseases and insect pests; and to cable this information to the Department of Agriculture together with important crop reports and notice of material changes in crop conditions occurring in the interval between official crop reports.

With the latest and best information of this kind available, the Department of Agriculture will arrange for the prompt and widespread dissemination of the essential facts through the press and through regular and special printed reports. If we had at least fifty well trained men in foreign fields to assist foreign nations in establishing a reliable crop reporting service, and to assist in introducing American agricultural products to the people of the nations where they are stationed as well as to keep American agriculture advised as to crop conditions, it would go a long way toward creating an outlet for the great surpluses we have on hand at the present time. 


\section{FINANCING FARMING}

\section{J. D. Phillips, Chairman of the Special Committee on Farm Finance,}

State Division American Bankers Association, Green Valley

$\mathrm{HE}$ farmer the same as any other business man, is in need of funds to use in the operation and development of his business. Some of these funds are used on the commercial side of his business and are of short-time maturity, and some are needed for the investment side of his business and naturally extend over a long period of years. Before commencing on the rural credits end of this address, I want to say something about the Federal Reserve Bank; for the farmers are as much interested in the Federal Reserve System as they are in a system that will provide for them long-time credit at a reasonable rate of interest.

The Federal Reserve Banking System is the greatest financial legislation ever enacted into law in this or any other country. It is not perfect of course, but it has been the financial life-saver not only of America but of the Allied countries as well, during the terrible, trying, distressing, nation-wrecking and soul-wrecking time we have been recently passing through in the World War. While this law needs some amending before it will become attractive to the country banker, yet be that as it may, over nine thousand of the thirty-two thousand banks of America are members of the system, with about sixty-nine per cent of the banking resources of the country connected with the Federal Reserve Banks. If in due time, and in the natural course of business events, it is learned by actual experience that the Federal Reserve Banks can pay a small rate of interest on required reserves, and such an amendment should be enacted into law, it would be but a very short time until every eligible bank in America would join the system. The making of over one hundred per cent per annum by several of the Federal Reserve Banks, during the past two years, is probably responsible for the belief that they will always be able to pay at least two per cent on required reserves without encroaching on commercial banking in any way. Should the experience of the banks in the next few years prove the fallacy of such an opinion, it will of course stop the agitation along these lines for all time; but on the other hand, should actual experience, after due trial, without hastily jumping at conclusions, prove the theorists to be wrong, no power on earth can stop legislation along the above named lines.

There has been a great deal of unwarranted criticism, principally by politicians, against the officers of the Federal Reserve Banks and 
the Federal Reserve Board, in regard to their dealings with the agricultural needs of the country, it being claimed that the farmer has not received his just proportion of assistance during the trying times we are now passing through. A careful analysis of the situation proves the very opposite of this to be true.

According to a report made by Governor McDougal in January, 1921, all the member banks of a great agricultural state had borrowed at one time 470 per cent of their reserve deposits, or in other words almost five times their required reserve; while the largest borrowing bank in the district had 233.3 per cent of their reserve deposits borrowed and all member banks in Chicago had 143.8 per cent borrowed. On October 1, 1921, all member banks of this agricultural state had 344.4 per cent borrowed, while the largest bank in the district had 21.9 per cent borrowed, and all member banks in Chicago had 40.1 per cent borrowed. I don't believe that we farmers have any fault to find with the Federal Reserve System, in the treatment we have received through the country banks, when the facts are known.

Another thing, the Federal Reserve Banking System saved every section of this country while the whole world was going on to the rocks of financial chaos. The Federal Reserve Banks of the North, without compulsion of any kind, went to the assistance of the agricultural interests of the South and West. At one time the Federal Reserve Bank of Cleveland alone, loaned to the Reserve Banks of the West and South no less than $\$ 145,800,000$.

While the Federal Reserve System has performed its duties in supplying the farmer and others with short-time credits, the Federal Farm Land Bank has not done so well in supplying funds for the permanent, or investment, side of the farmer's business. This business has been handled by country banks, investment bankers, mortgage loan associations, lawyers, or most anyone else who could get enough money together to make a loan on the most favorable terms possible to themselves. I do not wish to be understood as finding fault with the men in this kind of business, because I am one of them; it is the system that we are after and hope to correct if possible.

For the past eight or ten years I have been profoundly impressed with the need of some means whereby the investing public and the holders of farm mortgages could be brought together, but until about a year ago our ideas have all been of an abstract nature. In the latter part of February, 1921, the Executive Committee of the State Bank Division of the American Bankers Association met in New Orleans and this subject was thoroly discussed by the farmer member (your humble servant) of that committee. At the next convention, 
held in Los Angeles, the special committee of five on Farm Finance, of which the speaker is chairman, was appointed.

This committee met in Chicago, and after considering the matter decided it would be better to develop machinery already established than to build new machinery. A subcommittee was created to further consider the matter and recommend whether in their judgment an amendment to the Federal Land Bank Act was the right thing. The subcommittee has had a number of meetings and a joint conference with a committee of the American Farm Bureau Federation, and our opinion is that the law should be so amended that all incorporated banks might become members of the Federal Farm Land Banks. Such an arrangement would immediately provide thousands of well-equipped, permanent, local headquarters for the system. It would also insure the services of experienced financial men, would guarantee the making of safe loans based on conservative values, and would save all the overhead costs of local associations, for the banks could handle the additional business with little, if any, additional overhead expenses. Member banks would be required to subscribe to the capital stock of the Federal Land Bank in their respective districts.

Commissions would be allowed member banks for originating mortgage business, the same as the law now provides for farm loan associations; and the same compensation would be allowed member banks for collections of interest and amortization payments, the supervision of the payment of taxes, and the submission of occasional reports to the Federal Land Banks.

All the duties of the local associations would be assumed by the member banks; but while they would guarantee the genuineness and regularity of each loan they should not be required to guarantee the payment of the loan, for it would be unwise and unnecessary for the banks to assume this contingent liability. Any farm loan that cannot stand on its own individual merit, without the aid or assistance of other loans or the endorsement of any organization of any kind, ought not to be made. Under the double safeguard of the judgment of both the bank and the Government, there could be no excuse for ever losing a dollar on a single loan. Under such a system, the farmer would do his business through his local banker, the one person to whom he prefers to go with his financial problems; and the banker in turn could supply his farmer customers with the needed funds for their investments without freezing up the assets of the bank to the danger point. 
There is no better security in the world than a farm mortgage, properly made, not even a Government bond itself. While I have no desire to place any security above a Government bond, I do wish to say that when farm mortgages become worthless in this country, the Government obligation will have little or no value. The Farm Loan Bonds, based on such a security, ought soon to become very popular with the investing public, and hence ought to supply to the farmer the necessary funds for his investment needs at a rate of interest that would compare favorably with industrial undertakings that finance their fixed investments through long-term bonds.

Up to the present time the Federal Land Banks have sold that portion of their bonds not taken by the United States Government, through selling syndicates made up of the leading bond houses of the country, but a sufficient number of the bonds have not been sold to make possible the continuous operation of the system. With a wellorganized sales force, the Federal Land Board might act as a syndicate manager of future selling syndicates, including the leading bond houses, mortgage companies, and the member banks throughout the country. Under this plan each offering of bonds would be sold through the organization of a national selling campaign that would carry the appeal to every investor in the land. This would not only insure the rapid sale of the bonds, but would make possible their distribution at the lowest underwriting cost consistent with good service on the part of the distributors. And, as Mr. George Woodruff said in his address before the convention of the American Farm Bureau Federation at Atlanta, Georgia, "In order that Farm Loan Bonds might enjoy a continuous and broad market it might eventually be deemed wise for the Farm Loan Board to list them on the principal exchanges of the country, as was done with Liberty Bonds, and their popularity as a medium for safe investment of the savings of the people should ultimately become second only to that of the bonds of the Nation itself."

With the Federal Land Bank Act thoroly Americanized and developed along the lines I have been talking about, we will have an institution rivaling, if you please, in grandeur, strength, and ability to serve along its particular lines, the greatest financial institution ever established in the world for commercial purposes, namely, the Federal Reserve Banking System. With these two banking systems in the country, properly functioning, I do not believe there will be any need for an intermediate financial institution to care for the so-called two- and three-year paper that we hear so much talk about in political circles. 


\title{
THE BUSINESS OF FARMING IN SOME OF ITS LARGER ASPECTS
}

\author{
Thomas Nixon Carver, Harvard University
}

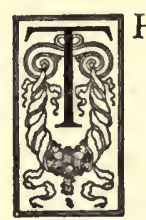

HE BUSINESS problems of the farmer are of two kinds, administrative and commercial. The first has to do with the wise direction of the working force of the farm in the production of crops, the other with buying and selling. The latter grows more and more important with progress because fewer and fewer things are produced on the farm while, at the same time, a greater and greater variety of things are used on the farm or consumed by the farmer's family. This requires more and more buying and selling. The farmer's prosperity will therefore depend more and more on his skill as a buyer and seller.

\section{Administrative Problems}

The administrative problems, however, are still of great importance. These consist in the directing of the whole productive force on the farm in the growing of crops and animal products. The acute phase of this problem, however, consists in paying expenses out of receipts. Almost anybody could run almost any business if he did not have to pay the bills. Many a man can grow good crops and breed good animals, who can't keep expenses down below the price at which they can be sold. Contrary to a rather widespread opinion among farmers, farming is not an exception to the general rule. It is no harder to pay the bills out of the receipts in farming than in any other business. It is inherent in the very nature of competitive industry that there should be failures. No matter how good a business man you are, speaking absolutely, if you are much below the average, speaking relatively, you will never be able to pay your expenses out of your receipts. Other and better business men than you are will offer so much to get labor, raw materials, machines, equipment, etc., and offer their products at so low a price, that you will be unable to stay in the same game with them. Your wage bill, your deterioration charge, your interest and other overhead expenses will be more than your receipts will cover. If your competitors were not quite so efficient and would not offer quite such high wages for labor, or quite such high prices for raw materials and equipment, you could, of course, cut down your expenses. If at the same time, they would not offer the finished product at quite so low a price, you could increase your re- 
ceipts; but the difficulty is that your pesky competitors will keep on bidding against you, offering high prices for what you have to buy and low prices for what you have to sell, thus forcing you to the wall unless you are approximately as good a business man as they are. If you fall materially below the standard set by them you will fail. There is no business or profession to which this rule does not apply just as definitely and rigidly as it does to farming.

\section{Prices and Profits}

This being the case there is no such thing as "cost plus ten per cent," or "a living plus ten per cent" for any except the more capable farmers, if the ten per cent is to be realized on the price of the land as well as on the rest of the investment. There will always be a considerable number who are just hovering on the margin, and another number who are below the margin and headed toward bankruptcy. This cannot be prevented, even by government price fixing. If the government were to fix the price of corn at two dollars a bushel and maintain it, guaranteeing to every farmer without exception that price, it would still be almost as difficult for the inefficient corn grower as it is now. To begin with, the price of corn land would go up. If any of you own good corn land, you would not sell it under those conditions at the price which you are now willing to take. If you are contemplating buying corn land, you would be willing to pay a higher price, under those conditions, than you are now willing to pay. This competitive bidding for land would go on precisely as it does now. The best business men among corn farmers,-that is, those who could organize the working force of the farm so thoroly as to keep expenses down or to get the largest possible number of bushels per unit of expense-could afford to pay and would, as a matter of fact, pay a higher price for corn land than the less capable farmers could possibly afford to pay. The inefficient farmer would have just as hard a time paying for his land if he bought it, or paying rent for his land if he rented it, as he now has. Again, the efficient manager who could so direct his labor force as to get more corn per man employed than the inefficient farmer, could afford to pay higher wages for his help. The poorer farmer would be crowded to the wall just as definitely as he is now. He would find it just as hard to pay these high prices for farm land, and high wages for farm labor, and high prices for farm machinery, out of the receipts of his two dollar corn as he has in normal times to pay the lower prices or the lower rents, wages, ctc., out of his receipts from one dollar corn. Of course, the 
farmer who gets his land before the rise comes, would enjoy the advantage of owning higher priced land, and could get more money for it if he ever decided to sell.

\section{The Unit of Organization}

Again, this is not peculiar to farming. The efficiency with which the farmer organizes and directs the working force of his farm has many phases, and depends upon the solution of a vast number of detailed problems. Almost every business, if it is organized at all, is organized around some unit, such as a power plant, an expensive piece of machinery, or a rarely endowed manager. Some farming enterprises are organized around a mule, a tractor, a plot of land, a family as a working unit, or a manager. In every case the size of the enterprise is determined by the capacity of the unit around which the business is organized. Where land it not a merchantable commodity, the acreage of the farm itself is not easily increased or decreased. It becomes, therefore, the unit around which the business must be organized, and the size of the business is necessarily determined by the capacity of the farm. Where land is a merchantable commodity, the acreage can be increased or decreased to suit the capacity of the manager. It is his capacity, therefore, rather than the predetermined acreage of the farm that determines the size of the business.

Where the predetermined acreage of the farm is the unit, the question is, how intensively to cultivate that acreage; that is, how much labor and capital to apply to its cultivation. The answer is obvious to every student of economics: As many units of labor and capital must be applied as will, one year with another, enable the last units applied to just pay for themselves; or the last application of labor and capital on the farm to just pay its cost in the increase of yield.

Where there is no predetermined acreage, the manager must regard his own capacity, rather than the size of the farm, as the limiting factor. That is, he must increase or decrease his acreage as freely as he would his labor force or his supply of tools and equipment. But he must remember that his capacity is as limited as is that of his land or that of any part of his equipment. If he tries to run too big a business, he must of necessity give somewhat less attention to details. $\mathrm{He}$ must spread himself thinly, as it were, over a large business. $\mathrm{He}$ must, however, enlarge his business until the last unit of a combined factor "land-labor-capital" just pays for itself. If he stops short of this, so that an additional unit of "land-labor-capital" would more 
than pay for itself, he will be losing that profit. If he goes too far, so that this last unit does not add enough to the total product of the business to quite pay the additional cost, - in short, if it does not quite pay for itself,- - he loses money on it and reduces his free income.

\section{Balancing the Different Factors of Production}

As to the balancing of the different factors of production in his business, the rule is that the last unit added to each factor must add exactly as much to the product of the whole as the last unit added to each of the other factors. This would be a perfectly balanced farm business. If, for example, a farmer has so much land and so little equipment that the last forty acres of land adds less to the total crop than would have been added if the price of that land had been spent on tools and labor, the farm is not well balanced-the farmer is land poor. It would pay him to sell some of his land and put the money into labor, equipment, etc., if he cannot otherwise balance his farm. This illustration could be multiplied or repeated with respect to each and every item in the farmer's business inventory. "Nothing in excess" must be his ideal; but that ideal is not realized until the last unit in each part of his business has exactly as great marginal productivity as the last unit of each and every other part.

\section{The Commercial Problems of the Farmer-Efficiency IN BARgAINING}

The commercial problems of the farmer are all summarized in the question, how to increase his efficiency in bargaining so as to buy and sell to better advantage. More and more the economic world is realizing that there is a distinct difference between efficiency in production and efficiency in bargaining. Efficiency in production consists in turning out the largest product in porportion to the sum of human energy expended in the work of production. Efficiency in bargaining consists in buying a given quality at the lowest possible price, or selling a given quality at the highest possible price. In many industries the size of the business unit is determined quite as much by the question of efficiency in bargaining as by the question of efficiency in production. Many of the supposed economies of the trust were not economies in production at all, but mere advantages in bargaining. Later experience has demonstrated that there were few, if any, real economies in production in the trust form of organization. This is not saying, of course, that there were not many economies in fairly large-scale 
production, but we have learned to be skeptical of any alleged economies that cannot be reduced to a purely mechanical basis. For example, it takes a large power plant and a lot of powerful machinery to roll even one steel rail. When you once have this large equipment, of course it pays better to keep it busy. Here you have a definite mechanical reason for fairly large-scale production.

From the standpoint of bargaining, however, the large concern has many advantages over the small concern. It can afford to maintain a larger selling organization with agents located everywhere, which agents can "get there first," before the scattered agents of the smaller concern can get around. Being able to buy its raw materials on a larger scale, it may succeed in getting better bargains. It may also be able to handle its labor situation more effectively and make use of cheaper grades of labor than the smaller concern. In various ways, by either buying or selling to better advantage than the smaller concern, it may beat it out.

The seller is a weak bargainer when the buyer has many other opportunities to buy. The buyer is weak when the seller has many other opportunities to sell. Collective bargaining on the part of sellers reduces the number of other opportunities open to the buyer; when practised by buyers it reduces the number of other opportunities open to sellers. It is dangerous, first, because it is a game that both sides can play; second, because it may become a means of extortion instead of a means of defense.

\section{When Does Collective Bargaining Cease to be a Means of Defense and Become a Means of Extortion?}

This is one of the most important questions now before the world. When the world really answers it, things will begin to be uncomfortable for those who are caught using it as a means of extortion, whether they call themselves merchants, manufacturers, labor unions, or farmers. The world will tolerate a good deal of collective bargaining so long as it is a means of defense on the part of those who cannot bargain for enough to give them a decent living. It will not stand much more than that.

Just now our farmers are weak in bargaining power. They are justly inclined to turn to collective bargaining as a means of defense. I warn them, however, that their present weakness is temporary. Europe is impoverished and not able to buy our surplus at remunerative prices. Our farmers are therefore forced either to sell it to them at prices which they can afford to pay, or not to sell at all. They are 
wisely choosing to sell at such prices as they can get. Our farmers are thus feeding Europe at a very low price. This cheap food will be the chief factor in the rebuilding of Europe. The difficulty of selling to them at a remunerative price is increased by the fact that Europe has no money with which to buy our surplus and must pay in goods. Tariff legislation hinders her paying in goods. Thus our government is deliberately reducing the power of European countries to buy our surplus, and thereby forcing our farmers to take still lower prices for their surplus than they would otherwise have to take.

When Europe again resumes normal production there will be a pre-war demand for American farm products. The American farmer will then come into his own and will no longer need collective bargaining as a means of defense. If he uses it at all, he will be using it as our trusts formerly did and as some of our labor unions are beginning to use it, as a means of extortion.

Consider this in connection with another fact; namely, that our farmers are already a minority. That being the case, they cannot prevent hostile legislation. When the majority who are not farmers discover that the minority who are, are using collective bargaining as a means of extortion, our farmers must look out for hostile instead of friendly legislation.

It is interesting to notice at this point a fundamental contrast between bargaining power and voting power. In the case of any economic class the more numerous it is the greater its voting power, but the lower its bargaining power, and vice versa, the fewer its numbers the greater its bargaining power and the less its voting power. During the decades of the over-rapid settlement of our western lands, the farming population was numerous relatively to the rest of the population and had great voting power, but its bargaining power was low and all agricultural products had to sell at a low price. The tendency at the present time is for our farming population to become relatively less numerous, - that is, to increase less than other classes. This is materially increasing its bargaining power, as evidenced by the higher prices at which farm products sell; but it is correspondingly reducing its voting power, and it will never again be able to exercise even the moderate amount of control over the policies of the Nation that it has exercised in the past. This weakness, however, if it be a weakness, is much more than compensated by the higher bargaining power that is coming to the agricultural classes.

Collective bargaining, however, may have two very distinct meanings. So long as it is confined to cooperation, in order to get 
the advantages of buying by wholesale or of selling in large quantities so as to be able to advertise and attract buyers, there is not and never can be any valid objection to it. It is only when it reaches the stage where it is able to keep the entire supply off the market and thus "hold up" the buying or consuming public that it becomes uneconomical and dangerous. As suggested above, so long as this extreme method is used by the very poorest members of society who are obviously not able to get a decent income otherwise, the world is very tolerant; but the minute it begins to be used by people who are already as prosperous as, or more prosperous than, the average of those of whom they are taking advantage, the latter will rebel or will launch a counter attack.

\section{Effect on Land Values of Fluctuations in Agricul- TURAL Prosperity}

I have suggested already that the present depression of agriculture is abnormal, and that there are better times ahead for all our farmers. It does not take a very long memory to convince one that for several years before the outbreak of the war, agriculture was on the up-grade. The rise in prices was very general, but the rise in agricultural prices was a little more rapid than the rise in the general price level. As soon as this present aftermath of the war is over, there is every reason to think that the pre-war tendency will reestablish itself.

These extreme fluctuations in agricultural prosperity furnish an interesting problem. Contrary to a very general impression that agriculture is the most stable of all industries, there is one important sense in which it is the least stable of them all. Perhaps it would be clearer to say that in some respects agriculture is a relatively stable industry, but in other respects it is one of the most unstable of all. The instability is associated with the price of farm land and its relation to the price of farm products. This relationship can be expressed generally by the proposition that a relatively slight change in the price of farm products is normally and logically followed by a vast change in the price of farm land.

This may be illustrated as follows. Let us suppose that for a considerable area of the lands of the corn belt it costs, one year with another, fifty cents to grow a bushel of corn, figuring in every element of cost, including the farmer's wages of superintendence and interest on his equipment. If the price of corn, one year with another, is exactly fifty cents a bushel and is not expected to go any higher, corn land is worth exactly nothing. That is to say, the average corn farmer 
would be as well off if he worked for wages, let his capital for interest, and abandoned his land, as he would be if he kept his land and tried to grow corn. He would have no motive for holding on to his land and no one else would have a motive for buying his land.

Suppose, however, that the price of corn should rise to sixty cents a bushel and it was expected that it would remain at this level, one year with another. There is now ten cents a bushel surplus. Obviously, no man would abandon his land under these conditions. $\mathrm{He}$ has a motive for keeping it; and there would be plenty who would be glad to buy it at some fair price. In other words, no man could make as much by abandoning his land and letting his capital at interest as he could by keeping his land and growing corn.

How much advantage would his land be to him? Well, let us suppose that he can grow fifty bushels of corn to the acre on the average and makes ten cents on each bushel. He then makes five dollars on each acre of land. Five dollars capitalized at the rate of five per cent would be one hundred dollars. One hundred dollars would be, therefore, the logical price for an acre of that land. Now a rise from fifty cents to sixty cents a bushel is not so very violent, but with the figures which I have assumed, it would make the difference between no price and one hundred dollars an acre for farm land. Again, assume that there is another rise of ten cents a bushel in the price of corn, the expenses of growing the crop remaining the same. A change from sixty cents to seventy cents is not so very violent, but this would exactly double the logical price of farm land; for now, instead of making ten cents on each bushel, he makes twenty cents, clear, over and above the expenses of growing the crop. Translated into acres, he now makes ten dollars an acre instead of five dollars. Capitalizing this ten dollars at five per cent makes two hundred dollars, the logical price of an acre of land, instead of one hundred dollars. In short, an increase of one-sixth in the price of corn produces logically a doubling of the price of farm land. A similar fall in the price of corn would produce a similarly violent fall in the price of farm land.

\section{To Buy on Credit a Hazardous Undertaking}

In this country, where the tendency is for farmers to own their own land, they are very likely to measure their own prosperity in terms of the trend of land prices. It is inevitable that there should be very wide fluctuations in land prices. Of course, this is not likely to have a great deal of influence on the farmer who owns his land 
free from debt and is not thinking of selling; but it is also a fact that in this country more than in any other, land is a merchantable commodity, is frequently bought and sold, and when bought, is frequently bought on credit. To buy on credit an object which is subjected to such violent fluctuations in value is a rather hazardous undertaking. You may gain very largely, and then again you may lose very heavily. In other words, farm land is one of the most uncertain and hazardous of all investments.

I mention this for the reason that it has been frequently stated in recent years that farm lands are the safest of all securities as a basis for credit. That is a proposition which may sound well on a political platform, but it is not true, in fact; and they who have taken it literally, especially in the recent land boom in the corn belt, have learned to their extreme sorrow that it is a dangerous fallacy.

One of my colleagues, in a recent attempt to be facetious, has remarked that agricultural economics is a kind of mental agriculture. If so, that is not enough to condemn it. I believe that there are a good many farmers scattered through the corn belt today who would be materially better off at this moment if they had practised a little more of this kind of mental agriculture,- the kind that consists in analyzing the basis of the value of farm land.

\section{"A Good Living and Ten Per Cent"}

"A good living and ten per cent" has been adopted as a kind of slogan for an agricultural campaign. This does not sound unreasonable; that is to say, the conditions ought to be such as to make it possible for any first-rate farmer to realize that or more. I wish to contend, however, that for the inferior farmer, or the farmer who is materially below the average, this is a goal that is forever unattainable, if the value of the land is considered a part of the investment on which he is to realize ten per cent. No matter how good a farmer he is, if he happens to be materially below the average of those who are competing with him for land, labor, and equipment, he never will be able to attain this goal while the world stands. As I suggested earlier in this paper, his more efficient competitors will bid so high for land as to make it impossible for this inferior farmer ever to realize ten per cent on that high price.

There is, however, one very important use that can be made of this slogan, or one very similar to it. I will explain this use by first mentioning what happens to a business corporation that fails to pay all the expenses, including the salaries of its officers. In a case of this 
kind, everything is down in black and white; and the corporation owes its managers salaries just as definitely and has to pay these salaries just as certainly as it has to pay for its raw materials, its fuel, or its machinery. When it fails to pay all expenses, including the salaries of all its office force, it is a bankrupt corporation and must be liquidated. Too frequently the farmer does not hold his farm to the same strict accountability as the business corporation is held. The farm has to pay for its fertilizers and all its other materials with deadly certainty, but, in present practise, it is not required to pay the farmer, the farm boy, or the farm wife definite salaries at all. Too many of them go on working without any salary, or with only half salary, and keep the farm going when it ought to be bankrupt and its affairs wound up. If such a campaign of education could be carried through as would persuade every farmer to run his own farm so as to pay a fair salary for himself and for all his family who actually work, a good many of our less well managed farms would be bankrupt and liquidated already. This would be largely, of course, a matter of accounting. If the accounts were so kept as to show exactly how much the farmer was getting for his work and that of his family, and he were convinced that he could get more by working for somebody else than by working for himself, and if he were to wind up his business as promptly as the corporation managers close the corporation that fails to pay salaries along with other charges, it would be an excellent thing for the farming industry over the entire country. These farmers would make more if they would give up farming and work for wages; and the other farmers would be relieved of the competition of a good many farms that are not now paying operative costs. I suggest, therefore, as a goal to be striven for, "Fair wages for every farm worker plus five per cent on the investment." That is a goal that is attainable, and when it is attained it will mark a very definite improvement in the economic conditions of the farming population. 


\section{THE UNIVERSITY AND THE FARM}

\section{David KInley, President of the University of Illinois}

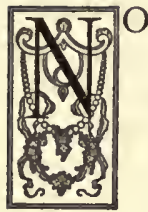

ONE can turn his attention to the subject of agriculture in the United States without thinking at once of its condition at the present time. Therefore, when a conference on agriculture is called it is inevitable that people should expect a discussion of the present agricultural depression. This, however, was not the purpose of the conference called at the University. The purpose was rather to consider the direction or trend of the development of agriculture in Illinois in the next decade or two, with special consideration of the part that the University College of Agriculture and the Agricultural Experiment Station can or may play in that development. In any conference on the general subject of agriculture today, three problems present themselves: the problem of the present depression; that of the improvement of existing agricultural practises, technically and economically; and the problem of the future agricultural methods. As indicated above, a fourth point in the present conference is the relation of the University to that progress.

Altho this conference was not called for the purpose of discussing the present depression, I may be pardoned if I turn aside a moment to mention it. We have had all sorts of explanations given and all sorts of remedies proposed. Most of the explanations and remedies have no relation to the subject. Most of the explanations do not explain, and most of the proposed remedies would make the situation worse. In fact, no one can give an adequate explanation of the situation or an adequate remedy for its improvement. It is curious that in an age when the medical profession is relying less and less on drugs for the cure of disease and more and more upon the healthy, slow processes of nature, the social doctors are facing the other way and relying more and more on quack remedies through legislation than on the operation of natural economic and social forces.

We all agree, of course, that the present situation is the result of the war, whatever the words may mean. It can be established, I think, that not only did the processes of the war take out of cultivation vast areas of land formerly used to produce food, but it also reduced the consuming power, that is, the purchasing ability, of the world. Even this statement needs explanation, but this is not the place for it. Moreover, the demands of war gave a direction to agricultural production, in this country at any rate, which distorted 
somewhat seriously the course of normal agricultural production. In addition, there are the influences due to the disturbed state of the currencies of the world; the political unrest, which is both a cause and an effect; and the economic disturbances in other than agricultural lines. So far as the farmers of Illinois and the United States are concerned, they were led to produce abnormally in some directions, relying on the high prices of the war, artificially stimulated and held up by government action. They were called on, for example, to supply wheat, and they furnished it from areas which were naturally better suited to corn; for of course the dominating factor in the choice of a crop was the price. I think there cannot be found in history a more illuminating.illustration of the evil consequences of government interference in economic life than has been furnished by the government activity in industry and agriculture during the recent war. The foolish currency and credit policies of all the important governments during the war, and the ultra-foolish policies of some of them since the war in the great inflation of currency, have made the situation worse. Thousands of people are starving in some parts of the world which are accessible by ordinary means of transportation, because the currency and credit conditions are such that they cannot buy the things needed to keep them alive.

Looking at the situation in a large way, the first thing necessary to the restoration of normal conditions in agriculture and industry is the cessation of currency and credit inflation by Germany and other countries, the restoration of decent conditions in Russia, and the consequent reestablishment of international trade. The debts of foreign countries to this government should be funded at a reasonable rate of interest for a long-time period to assist in the restoration of normal rates of exchange. A good many other things are necessary, but these measures would go a long way toward restoring confidence and setting the world to work.

\section{Some Outstanding Facts Determining Future Agricultural Development}

With reference to agriculture in Illinois and its future development, there are some apparently outstanding facts that we must consider in trying to determine where we are going.

While it is true that, taking the country as a whole, a dozen years ago less than half of our total land area was in farms, yet less than a fourth was improved and less than a sixth was tilled. Nevertheless, the available tillable land of the country is pretty well taken up, and further great expansion in agriculture must come from some 
other method than by simply taking up more land. The area of improved land has, of course, increased pretty rapidly in the past decade or two, but it has not increased as fast as our population. To be sure, improved methods of agriculture might render an equal rate of increase unnecessary. Still there must be some relation between the rate of increase of population and that of the increase of improved farm land in a country where land is still open to occupation. When the land has all been occupied, then the relation must be different and a larger number of people must be fed from each acre. Speaking generally, we have reached that condition in the United States and in Illinois. In other words, we have reached the point of what is called decreasing returns under given conditions of agricultural practise. In Illinois in 1920, the improved land in farms was approximately threefourths of a million acres less than it was ten years before. In the meantime, the estimated value of all farm property had risen from 3.9 billion to 6.7 billion, two billions of this increase being in land, three hundred millions in buildings, and one hundred and forty millions in implements and machinery. In other words, the value of the land increased in the decade 70 per cent, that of the buildings 73 per cent, and that of implements and machinery 202 per cent. These facts also, due regard being had to other conditions, may fairly be interpreted as evidence that we have reached the point of decreasing returns under given conditions of agricultural practise.

Again, the average value per farm has increased nearly five times in the past thirty years, practically all of the increase being in land and buildings, and the main part of it in land.

Another significant fact for Illinois is that, generally speaking, the number of farms of every size has decreased excepting those between one hundred and five hundred acres. The tendency seems to be that the usual farm shall be between those limits. Another fact of some importance, altho I cannot help thinking that it is a temporary phenomenon, is the change in the character of the cereal crops in the decade just closed. In the ten years closing in 1919, there was a decrease of 21 per cent in the acreage of corn harvested and an increase of nearly 88 per cent in the acreage of wheat harvested. This change was probably due to the demand of the war, exerting itself through the higher prices offered by governments for wheat. The result, of course, was the devotion of land, better suited to corn, to the production of wheat. In other words, the land was not being put to its most socially productive use, using the term "productive" with reference to total actual production. 
Again, the character of the animal industry of Illinois has changed in considerable degree in the past twenty or thirty years, altho it is true that there were more cattle reported in the 1920 census for Illinois than in the 1910 census.

Again, notwithstanding a large increase in population, largely in the cities, there has been, according to the best Census estimate, a reduction in the amount of milk produced in the state and in the amount of butter made, al tho the value of the milk, cream, and butterfat sold, and of the butter and cheese made, is estimated by the census to have increased 128 per cent.

On the social side, the Census shows a decrease in the number of farms operated by tenants; but the decrease is evidently all in the class of cash tenants, or the most independent class of tenants.

Summing these facts up, they seem to me to point in a general way to certain conclusions. First, as already suggested, they indicate that in Illinois, as elsewhere, we have reached the point where in our agriculture we must expect to raise larger crops per unit, or to get more products per unit, at increasing cost. If, in our attempt to raise our crops on high-priced soil at increasing costs, we find ourselves unable to compete with people raising similar crops on cheaper land in other parts of the world, we shall be obliged either to resort to a system of protection for agriculture, or we shall have to let part of our land go out of use, as did Old England and later, New England. We shall have on our hands the problem of abandoned farms. The obvious conclusion is that we must seek that kind of agricultural activity in which we are most efficient under our Illinois conditions. We must make the most economical use possible of our land and machinery.

We must also take notice of the fact that the industrial growth of Illinois is likely to be rapid in the next twenty-five or thirty years. Manufactories will be more numerous. That growth will bring to our doors a larger home market. Our agriculture may perhaps direct itself to supplying products peculiarly demanded by such a market. Still, again, since the value per acre and per farm has increased and will increase more, we must get a larger output per farm or per acre in order to make our investment pay.

Generally speaking, our policy in the past has been of necessity large farms with crops of a single character or cereal crops of two kinds. With the growth of a home market of industrial centers, there will have to be more small farms producing the things demanded for consumption in such centers. In other words, as population becomes denser, the most profitable farm may perhaps have to become 
smaller, its products more diverse, its cultivation more intense, its value per unit higher, and the products selected for growing those which are in greatest demand, and in the market where the net profit is highest.

\section{Agricultural Policy of the Immediate Future}

In the light of these facts, there seem to be certain conditions which will modify our agriculural policy for the immediate future.

In the first place, we are bound to conserve and, if possible, to increase the fertility of our land. We must not allow it to run down further; rather we must restore those parts of it that have run down. How to do this is a problem for the solution of which the farmers of the state are entitled to look to the University Agricultural Experiment Station for help. Much has been done in the study of the application of chemistry to agriculture. Little has been done in the study of the improvement of plant life, and in the study of plant disease and the remedies therefor, in order to give us a larger and more healthy product and to eliminate the waste of diseased products. This field is a proper subject for study at the University.

In the second place, it is clear that our cultivation must become more intensive. It is easy to say that we can raise seventy-five or one hundred bushels per acre in Illinois of this crop or that crop, instead of the forty or fifty that we have been raising. In the past a great deal of foolish talk of this kind has been indulged in. There has never been any doubt in the mind of anyone who is conversant with the facts that we could increase the output per acre of any of our crops, but at a cost. The farmer's problem, so far as he can control the amount of his production, is to get a product which, at the prices that can be secured for it when put upon the market, will yield him a net profit. Society's problem is to find a system of agriculture which will produce enough to meet the demands of men and women for living, at prices which they can reasonably pay, while at the same time letting the farmer have the profit necessary to induce him to continue his business and to prosper like the rest of the community. It is nonsense, therefore, to tell the farmer that he should increase his output per acre without showing him that the increasing cost of every additional bushel will be met by a larger market and an increased price per bushel. While, therefore, in the next twenty-five years Illinois agriculture is bound to be more and more intensive, one of the ways in which it may become so is by the discovery of methods of cultivation which will reduce costs of production. This, again, is a field for 
study and investigation by the University. These remarks apply to improvements not only in the technical processes of agriculture but in the economic processes involved in farming. We must find improved business methods for farming. The business side of farming, as has been said here repeatedly, is capable of great improvement. This is true not only of methods of marketing, which is a very popular subject of discussion today, altho it is not the cure-all for agricultural ills that many seem to think; but it is also true of other phases of the business.

In the third place, as I have already intimated, we may find it profitable to diversify our agriculture still more in the way of increasing those products which are in immediate demand for family consumption in cities and industrial centers, which are bound to become more numerous all over the state. It may be that in doing this the average farm will have to become smaller and the owner will have to devote himself to more lines of farming than many of our farmers are accustomed to now. I have no doubt that in time the farms of some of the states to the east of us, and perhaps in Illinois itself, will become more nearly like those of certain parts of the Old World and of the East, where population is dense, in the sense that each farm, so to speak, a complex of a large group of agricultural operations. The farmer raises a few cattle and hogs, various kinds of vegetables or garden truck, fruits, a certain amount of milk and butter, and perhaps a considerable amount of one or two of the grains. Under the conditions in which he lives, and his closeness to a large population, he has a surplus in each one of his products that he can sell at a profit.

In the next place, we must learn to make a better use of our untilled land. We shall undoubtedly find it profitable, if not necessary, very soon to increase the number of our trees. The best way to do this is for each farm to have its woodlands. Other land not under cultivation and not lying fallow will undoubtedly be more largely used for grazing purposes, even tho the use be temporary for particular farmers.

We must look forward, too, it seems to me, to an increase in our horticultural agriculture. There is no good reason, so far as I can see, why there should not be a great many small orchards as part of the farms throughout the State, as well as a few large orchards. It seems probable that such orchards can be made profitable to the farmer.

Other auxiliary agricultural enterprises, such as bee culture and poultry raising, will have to be more commonly engaged in.

Still again, the dairy industry of the state needs development and better organization. The demand for dairy products will grow as 
the population grows, especially in the neighborhood of cities and industrial centers. The dairy industry should become larger in the next decade or two, both as an independent industry and as a part of ordinary farming. In this line, as in others, the University's duty as it is supplied with means for the purpose is to cooperate with the practical farmer by studying conditions and trying to devise methods of expansion and improvement and to make scientific discoveries that will promote the progress of the industry.

\section{Economic, Social, and Business Improvement}

In addition to the group of activities and improvements thus far mentioned, there is also the very large field of economic, social, and business improvement in farming. Farming as a business has been sadly neglected. There is a good deal of popular enthusiasm at present about one aspect of the economics of farming; namely, that of marketing, and some on the general subject of farm organization and management. Farm organization may be regarded from the point of view of technical agriculture or from that of economics. From the former point of view, the farm should be so organized as to make possible the utilization of the best technical methods of production. From the latter point of view, the farm should be organized,- - that is to say, the capital invested in the farm should be so apportioned between different farm operations,-- as to yield the largest net profits from the processes to which it is assigned. We need a study of the apportionment of capital to diverse farming operations on farms of standard sizes. This would be a study of agricultural investment. To this the University should give its attention as soon as it can find means. We need, in addition, a study of the economics of farm distribution, involving marketing; warehousing (cooperative and other); transportation, whether by highway or by rail; markets considered with reference to their geographical distribution and their economic character; and a number of similar subjects. These are all proper subjects for study at the University, and it should be a part of the future policy of the state to provide means for the encouragement of these studies.

Again, we shall need in our Illinois farming better and more frequent statistical reports showing the actual conditions in the various agricultural activities of interest to our people, so that our farmers will be able more intelligently to determine what products to raise in each season and how most advantageously to sell them. 
We need to make a more profitable use of what are at present waste products on the farm. On this subject, as on that of raising larger crops per acre, there has been much nonsense talked and written. Speaking economically, an article which has in it the possibility of usefulness is not wasted when it is not used, if the cost of using it would be greater than the value obtained from it. From the farmer's point of view it is not waste to use corn, or even wheat, for fuel if he can get his heat per unit at less cost in this way than by buying coal and there is at the time no more profitable use open to him. It is not waste from the producer's point of view to let the apples rot on the trees or the oats remain uncut, if it would cost more to put them on the market than the value that would be received from them. There are technical and economic problems in this question of waste that are waiting for solution. We are not yet making profitable use of our cornstalks or probably of some other products that are commonly thought of as waste.

Agriculture in Illinois in the next twenty-five years needs, as indeed all other businesses and industries do, an improved system of taxation. There is a great lack of knowledge of the real incidents of our taxes as they are at present, and there is undoubtedly a good deal of inequity in our present system of taxation. It is due in large measure to the retention of the old general property tax under which it is possible, and indeed necessary, to place the heaviest burden on property that can be seen and therefore found.

Our next quarter-century of agricultural progress calls also for a simpler and less expensive system of land transfer. As some one has remarked, "I can buy a bond or a thousand bushels of wheat in ten seconds by the clock; but to buy a small tract of land involves an unreasonable amount of time, expense, uncertainty, risk, and vexation."

Still again, on the economic side there is doubtless some room for improvement in the banking and credit facilities open to the farmer. As everybody knows, the farmer requires both short-time credit and long-time credit. His short-time credit is in general character similar to that called for by the manufacturer. It depends on his personal reputation, his evident ability as a business man, and the probable value of his season's output. When a man borrows on the basis of security of this character, he must expect to be able to borrow only a part of the total valuation of that security in the mind of the banker. Yet I cannot help thinking that the part which the farmer is able to borrow is ordinarily less than the proportion which the business man in town is able to get. A somewhat parallel criticism could be made of credit facilities open to the farmer for long-time loans. 
On the social side, life in the country, must be made more livable. I do not sympathize with those who think that the farmer's boy and girl are more susceptible to the lure of the great white ways of the cities than are other boys and girls. I do not believe that the attractions of the city are in so large a degree as is commonly thought the cause of the exodus from country to city. Nevertheless, it is true that means of recreation and pleasure are less abundant and, on the whole, less refined in the country districts than they should be. This is a field for educational activity. It should begin with the local educational units, particularly the high school, each local community utilizing its resources to furnish proper entertainment for the young. It is a mistake for every community to look to the University as in some states is the practise, for its entertainments, lectures, and study classes. The local teaching staff should first be used and the University looked to for help only in those lines and subject with which it properly has to do.

It has been my purpose in these somewhat desultory remarks to state what seemed to me to be the conditions and the problems rather than to offer solutions of them. It is peculiarly rash for the layman to try to give a description of activities with which he is not familiar through being a participant. Yet the onlooker, who has a general understanding of the character and direction of activities of a particular economic character, may sometimes see their general drift more clearly than if he were immediately engaged in them. It is for that reason and with that feeling that $I$ have ventured on this unfamiliar ground. A man would be a fool who would attempt to prophesy for the next twenty or thirty years in Illinois agriculture. Yet I venture to run the risk of being called foolish by pointing out that in a general way we are headed towards a more intensive agriculture, towards a standard or model farm having one leading agricultural activity and numerous auxiliary agricultural processes, each of them yielding its own profit and all together yielding a larger joint profit than would be obtained from the pursuit of a single agricultural activity on that particular farm. We shall have larger crops per acre and, in time, either higher prices for them or reduced costs of producing them. We shall put our dairying, as a separate industry, on a firmer basis, and we shall make it a part of the work of every farm. We shall reclaim our waste lands and use them for forests and grazing. We shall restore our cattle industry by finding some method of low cost feeding, and we shall improve our economic organization and make social conditions more attractive. 
In all these things there is an opportunity and duty for the University to assist by its studies and discoveries. The time has gone by when the farmer looks with contempt upon the Agricultural Experiment Station. The Agricultural Experiment Station will have to widen its activities to include some economic and social aspects, and it will probably find it advantageous to change the direction of its studies in connection with fertility so as to add to them investigations in plant life that will enable us to get more healthy plant products and more of them at the same cost. 


\section{THE INTRODUCTION OF NEW CROPS}

\section{Charles L. Meharry, Attica, Indiana}

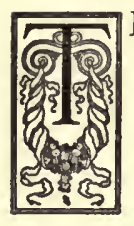

$\mathrm{HE}$ story is told of two lumber jacks engaged in the perilous job of rafting logs down a swollen and turbulent northern stream. The current and rocks were too much for the raft, and it broke up. Jim was plunged into the torrent. After a mighty struggle he managed to reach the surface with belly and lungs well nigh filled with ice-cold muddy water. His voice registered excitement and despair: "Bill, hurry quick or I'm a goner!" Jim grasped a stray $\log$ as it floated past, but the strong swift current carried his legs and body beneath the $\log$ and toward the surface of the water. Moreover, the log began to roll. At great risk to his own life, Bill reached Jim's log and was reaching for his collar when Jim caught sight of his own feet on the other side of the $\log$, where they had been driven up to the surface by the sheer force of the current. Again Jim spoke, but this time his voice indicated more self-control, and into his eye had come a gleam of courage and self sacrifice. "Look there, Bill! I think I can hold on a bit longer. Try and save the poor hick on the other side of the log. He's in head first!"

Should we farmers not try to visualize the entire world in its plight? May we not summon all our nerve and courage, and if necessary a certain spirit of sacrifice; for is not human civilization head first in the same muddy torrent of economic maladjustment through which we are struggling; and if she perish what is the use of living?

\section{"Let us then be up and doing, \\ With a heart for any fate; \\ Still achieving, still pursuing, \\ Learn to labor and to wait."}

There is much talk of late about overproduction of our important cereals and agitation for the introduction of something new to take their place. But the introduction of new crops needs more justification than that usually advanced; namely, that oats and corn are no longer profitable. It may be proved that overproduction is not troubling us so much as underconsumption, and he who heedlessly. curtails his production may awake some day to find that our statesmen and economists have succeeded in restoring the international political and economic balance, and that a hungry world is again 
ready for our bread. Such a man may find cause for meditation. Dean Davenport said recently that "Agriculture has national and international relationships, but they must be handled in the interests of public welfare, and not of selfish class interest." That is sound and fundamental logic. When we reflect that a large part of the world is starving and freezing, the talk of limiting production sounds like false economy.

Likewise, the new crop which does not find justification in one or more of about three words is not likely to prove profitable to its grower. Those three words are: Economy, Feed, Fertility.

If by introducing a new crop we may effect a saving, directly or indirectly, of cash outlay or labor, providing there is need for the product, there is justification. If in addition to economy the new crop furnishes not less but more food and raiment to society, at less cost, and at the same time increases the fertility and productivity of our soils, so that future generations may be fed and clothed,- - then indeed there is justification. We need look in but one group of plants for such crops-the legumes.

\section{New Crops Among the Legumes}

Among legumes we find three; a perennial, a biennial, and an annual, all of which are yet new to most Illinois farmers. The first is alfalfa, a great hay crop, which, however, lends itself but poorly to most rotation schemes and which, because of its conflicting harvest season and heavy yields, does not lend itself well in large acreages to the economical distribution of labor in the corn belt. In spite of these drawbacks and the plant's exacting requirements, alfalfa is too good and beautiful a thing to be ignored. Most of us could grow it in many of the irregular small lots and patches about the premises, which are too often waste places and eyesores. Many can use much more, but let us all use at least this much.

The second plant is the biennial sweet clover, a wonderful pasture plant and soil enricher. Not quite so exacting as alfalfa, it works better into rotations. Its carrying capacity is so great that truly it may be said that two animals may graze where but one ate before. The seed is cheap, and there is but one exacting requirement-limestone. Whether pastured by live stock or fed to the succeeding cereal crop, this plant is sure to enrich the soil, society, and the farmer.

The third plant, the annual soybean, is destined to become a great grain crop as well as a wonderful forage plant. Just at present 
it is as a forage plant that it finds greatest usefulness in Illinois. Practically every Illinois farmer should raise at least a few soybeans, for all they ask is a good seed bed and inoculation. Nearly everybody can find some space for a plant which will make a hay equal to alfalfa, or a grain as good or better than cotton-seed or oil meal; which will considerably increase the amount of silage he can grow per acre, or make a wonderful combination with corn to pasture off with live stock; which will tremendously reinforce his cornstalk pasture; or which, grown alone and plowed under, will add as much nitrogen to the soil as will clover. Finally, when a commercial demand becomes established for the seed, on account of its exceptionally high oil content, there will come to be a regularly established market for seed.

We need much new information; and we need to have it, as well as what we already know, much more widely disseminated before these three little-used legumes will really find their places in our agriculture. It has been but a few years since no less valued and influential a friend and adviser than Mr. Frank Mann, when asked to criticize our Champaign county farm and our practises said among other things that he believed we had too large a proportion of our land in legumes to be practical and economical. He said that that was a criticism he hesitated to make, but that it was his honest conviction. The criticism had our earnest consideration, but we have never obtained the consent of our minds to change our rotation, and we still doubt if it would be profitable to do so. Our rotation being corn, soybeans, wheat, and clovers, half the cultivated area is given over to the exclusive occupancy of legumes each year, and even wheat and corn have to share their homes with clovers and soybeans. Alfalfa we use, too, but not in the rotation.

\section{The Place of Alfalfa}

Alfalfa being a perennial, we have found needs more than two seasons to attain perfection. This fact, together with the exacting requirements of the plant, and the further fact that the average sized corn-belt field in alfalfa would be like the tail that once wagged a $\mathrm{dog}$, has given us pause whenever we have considered putting alfalfa into our rotation. The fact, too, that its harvest season conflicts with cultivation of the corn crop and sometimes with wheat harvest, makes it difficult to distribute labor economically, when too much of it is undertaken. But alfalfa is much too useful and beautiful a crop to be ignored. 
On nearly every farm there are a few small lots near the barn which seem essential but which for the greater part of the time are not in use. Because of their small size and often their odd shape these small areas are difficult and expensive to till. Now, we find that alfalfa fits into these odd areas splendidly. The overhead of seed-bed preparation is distributed over several years; we have our hay close to its storage places; we cannot easily overlook either the needs of the crop or its beauty. Nothing can be placed between the farm yard and the public highway that will more enhance the view, both from within and from without. Incidentally, no inexpensive change will so quickly raise the selling value of a farm as to frame the dwelling in alfalfa. I do not mean the yard, of course, but the area surrounding the yard.

Many of the important problems of alfalfa culture are farm management problems. We believe that alfalfa is primarily a hay crop. It is too difficult and expensive to establish to use for pasturing to any great extent, though for some forms of live stock it does make excellent pasture. But for hay it would be par excellence, the best crop, were it not for the fact that its season conflicts with certain other peak labor loads. How to avoid or overcome these conflicts is, we believe, the most needed detail yet to be worked out. It may be that, as Mr. J. W. Morgan intimated this week, the solution of the difficulty may be found by working with the corn crop as well as with the alfalfa. It may be that we are spending an unnecessary amount of time in the cultivation of corn. Have we been too inclined in most investigational work to see only the immediate crop, animal, or enterprise concerned, without enough consideration being given to the thing's relationship to the entire collective business of agriculture? If so, it would seem that cordial cooperation of those who concern themselves largely with the new study of farm management is greatly to be desired. Indeed, it is only when there is the most cordial, interested cooperation of all the various.departments of our College and Experiment Station that they really function normally and do the greatest good. Not only this, but cooperation and a spirit of helpfulness between the colleges and stations of our various corn-belt states, and between the experimentalist and the farmer himself, are also essential for the most rapid progress.

\section{Sweet Clover for Pasture and Fertility}

The biennial sweet clover lends itself better to the rotation and makes a more satisfactory pasture plant. Indeed, it is as a pasture plant and soil enricher that sweet clover is most useful. It makes 
good hay, altho alfalfa and soybeans are both better for that purpose. I was exceedingly glad to see the Agronomy and Animal Husbandry Departments cooperating on the South Farm last fall in the investigation of this pasture plant. Many of us are convinced of the great value of this crop, while many others still dispute it or are frankly skeptical. Much more exact experimental evidence is needed before sweet clover may occupy its rightful heritage.

\section{Need for Investigation of Clover Problems}

We need to know a great deal more about the factors governing the inoculation of all our legumes, particularly sweet clover and soybeans. Do such things as the calcium and phosphorus requirements of these plants affect the multiplication and activity of nitrogengathering bacteria; and does deficiency or abundance of rainfall do the same? Then how, why, and to what extent, as measured by the productivity of the land? Do these same factors affect the physiological functions of the plants and their composition? If they do, how do these differences affect the functions and growth of young animals that feed upon them?

We need to know whether very early pasturing of sweet clover is beneficial or detrimental to the plant. Is it wise to pasture it closely? If not, is it beneficial to clip it when it reaches a certain stage? If so, what is the best stage, and how many clippings are beneficial and economical? Does clipping improve palatability? Does it increase carrying capacity?

Shall we try to grow a clear stand of sweet clover, or mix other clovers or grasses with it; and why? What effect do the different plants in a pasture mixture have upon soil fertility? Is the amount of forage increased and its efficiency in meat making improved by mixing pasture clovers and grasses? If so, to what extent? And why, and how?

To what extent will the answers to all such questions affect our farm practises? We shall need the help of the economist to reach our decision.

Soybeans, reaching maturity in a single season, are much more adaptable than a perennial or biennial. Moreover the requirements for this crop are not nearly so exacting as those for sweet clover and alfalfa. The crop is more tolerant of an acid soil, for one thing. But just what effect will liberal applications of limestone, so benefi- 
cial and essential to sweet clover, have upon the growth, inoculation, and composition of soybeans? If it affects their composition, does it make them a better feed or poorer? Does it affect the oil content? The same questions might be asked concerning phosphorus.

\section{The Increasing Interest in Soybeans}

Soybeans, being planted in the late spring, have neither the vicissitudes of winter nor the competition of another crop to contend with. Interest in this crop has developed marvelously in the past few years, and the use of it has grown by leaps and bounds. This has been but natural, as seed prices have made soy culture very remunerative. The cost of production has been about the same as for corn on our farms (in many instanices less), and the gross returns generally greater. In the corn belt there has never been a commercial market for soybean grain other than for seed purposes. The grower has had to find his own market, and grade, sack, and ship the crop in small parcels, often to the corners of the land! This is a problem most farmers do not care to solve, tho we have not found it arduous, considering the compensation. However, several corporations are now promising an outlet for next year's crop, for oil and feed manufacture; and unless production should overtake this still rather modest source of consumption, soybean growing should prove quite remunerative, altho promising no such returns as we have been in the habit of expecting. Ultimately, I confidently expect soybeans to displace oats in our fllinois rotations to a great extent; but it would be a tremendous mistake to try to accomplish this in a single season, or even in three or four. A campaign of education is needed to exploit the uses of soybean oil and cake so that the industries and the feeder may appreciate their value and gradually increase the use of them. Our Household Science Department might do both the producer and consumer a great service by teaching the people the great nutritive and dietary value of soybeans as human food. Unless such educational work is pushed, the time may not be far distant when the sale of soybean seed will not be profitable on account of overproduction.

Should this occur, however, it should not deter any farmer from growing what soys he can consume on his own farm; and, by the way, practically every farmer ought to start with soybeans on that basis. We believe the College and Station should for the immediate present lay most stress upon the use of soybeans as a forage, while at the same time investigating the uses to which oil and cake may be put. 


\section{Some Things We Need to Know About Soybeans}

It seems to us that from now on less attention should be paid to variety tests, and more to standardization, nomenclature, selection, and certification. Both producer and manufacturer need to know how oil content varies with variety, and whether some varieties give up their oil more easily than others. They wish to know what correlation there may be between color of seed coat and the quantity and quality of oil, and the relative value of cake or meal from different colored seeds. Is there a difference in quality of cake produced by the different methods of oil extraction? We should know to what extent and in what manner, climatic and soil conditions influence the composition of the plant, especially the seed.

This Station has shown that soybeans planted with corn may reduce the corn yield. We should like to know how varying rates of planting affect the corn yield. Is there any symbiotic relationship between corn and soys in the same hill? Certain other stations have shown that the two plants growing together may produce a greater weight of silage than either separately. What is the increase worth? If we do not gain as many pounds of soybeans in corn as we lose in corn, are the soybeans which are produced worth more, as a supplement to the remaining corn, than the lost corn would have been? Is a field of corn and soys which is harvested by being pastured with live stock worth more than corn grown alone on the same field and harvested by man? We should have this data for all the meat animals. What will be the cumulative effect on soil productiveness of long continued practise of pasturing off crops? May we not have cordial cooperation between the Agronomy and Animal Husbandry Departments in solving such problems as these?

Considerable importance may be attached to certain laboratory studies by Dr. Hottes, of the germination of soybean seed, and a continuation of these studies is greatly to be desired, as they may reveal why some varieties have given uniformly better stands than others. They may settle, too, the much discussed question of what effect color of seed has on germination and longevity of seed. They may teach us the best methods of seed storage and care. We hope the pathologists will undertake to solve the cause and prevention of the bacterial blight of soys that we have observed during the past few years, and tell us why some of our best varieties have been the most affected.

We believe that experiments on the rate and manner of seeding should be continued and developed. We feel that managerial economy 
points strongly toward close seeding on well-prepared land, to be followed by rapid over-cultivation without too much regard for the individual plant. We feel that higher hay yields are to be expected, and more nitrogen fixed, where the land is most fully occupied.

Harvesting questions should also receive attention. Economy of material must go hand in hand with economy of labor. The latter becomes relatively more important as the price of seed comes down without a corresponding decrease in the cost of labor. We should know whether more than one soy hay crop may be grown on the same land in a single season. Some evidence points to that possibility. May soys be cut before blooming and survive the cutting? What yields of hay would they make at that stage? If they will not survive, may a second seeding be made which will yield a hay crop before frost?

What yield of ensilage might we get from a mixed solid seeding of sweet corn or pop corn with an early variety of soys? It might bring silo filling at a more convenient time on farms where soybean harvest and wheat seeding sometimes interfere with silo filling. What quality of ensilage would such a combination in varying proportions make?

How is the composition, palatability, digestibility, and yield of soy hay in tons and in pounds of meat per acre affected by the stage of maturity at cutting? What is the relative value of soybean straw or hullings compared to oat straw? Does it pay to hull soybeans and feed grain and straw separately, or will the hull tend to overcome the ill effects sometimes observed when feeding hulled beans? Will extraction of the oil overcome these ill effects? May they be overcome by any kind of supplemental feeds? Colorado lamb feeders find it practicable to harvest field peas directly from the field with lambs. Can we do it with soys?

\section{Fertility and Soil Physics Problems as Related TO THE LEGUMES}

Fertility and soil physics problems related to all these legumes need further study. The root systems of perennial and biennial plants, and the functions they perform, differ so much from that of the annual soybean that comparison is difficult. We should know the comparative manurial value, in whole or in part, or indirectly, after being pastured or fed to live stock. We believe the possibilities of both sweet clover and soys surpass red clover in some respects. Purdue records show that soys seeded after a wheat crop was taken off, grew 
over 13,000 pounds of material (including roots) containing 92.7 pounds of nitrogen. At the same station wheat after soys has yielded 5.5 bushels more per acre than wheat after corn. Should we not know what the cumulative effects of these legumes is to be on fertility?

Until we have answers to such questions as we have asked and many others equally important, Illinois agriculture will probably proceed rather cautiously in introducing alfalfa, sweet clover, and soybeans into its scheme of management, and justly so. Yet how badly we need legumes and how much economy to agriculture and to the nation might result from their introduction!

\section{The Solution of These Problems by the Experiment STATION}

In the introduction of these new crops into Illinois agriculture, our Experiment Station must be largely influential. Individually, the farmer cannot afford to do much experimenting, particularly at the present time. But a great deal may be done collectively, and there has hardly been a time when we needed to have so much experimenting done for us. In so far as our inquiries are in the interest of public welfare we have a right to ask the consuming public to help us solve our problems by helping to support our College and Experiment Station. It is the duty of the public to help to provide research workers who may in any way help to reduce the cost of living. This the Experiment Station may do by investigating problems relating to the growing and the use of such new crops as we have mentioned. It is only after disinterested scientific investigation by trained workers that the farmer can afford to venture far into untried enterprises.

Let us all then, whether we be producers, consumers, experimentalists, or economists, interest and concern ourselves that such new or little used crops as alfalfa, sweet clover, and soybeans be thoroly investigated, and see to it that the knowledge gained be disseminated to farmers; to the end that farm production be economically increased, thereby adding to the farmer's profit and at the same time lightening the consumer's burden of cost. Let us not forget, in contemplating the benefit to us individually, the thousands of hungry mouths and cold bodies in foreign fields. Above all, let us remember the succeeding generations of Americans and our responsibility for their welfare. Consideration for our children and their children's children should scarcely be second to the instinct for self preservation. 


\title{
FARM FORESTRY IN ILLINOIS
}

\author{
A. N. Аввотт, Morrison
}

(Lantern slides were used during the address, showing sandy and eroded lands, the effects of tree planting on sandy land, and woods where forest conditions were maintained.)

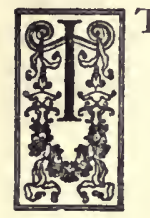

$T$ IS estimated that timber in the United States is being consumed four times as fast as it is being produced. The rapidly increasing prices of lumber products during the last two decades foretell the great timber scarcity which is now upon us. Our great white pine forests were exploited with the abandon of a drunken sailor. A heritage which properly managed would have contributed to the use of the people forever was destroyed in twenty years.

It is quite time that the Nation, the states, and individuals adopt a timber conservation policy. Much land is now cultivated, or has been cultivated, which is of small tillage value and is suitable for forestry. The most authentic sources of information indicate that there are three million acres of woodland in the state and six million acres more of non-agricultural land, making about twenty-five per cent of the land of the state of a character that invites serious consideration from a forestry standpoint.

Two features of forestry policy are apparent, the improvement of the woodlands which we have and tree planting on non-agricultural land. Just as a good stand of corn is necessary to secure the maximum crop, so a full stand of timber is necessary to secure the best results. Interplanting in scanty forested woodlands would seem to be the first step in a forestry program. For the best result stock should be excluded; indeed, in a fairly wooded pasture the grazing is of no great value, and the damage that stock can do to the young growth is considerable. Exclusion of stock permits the formation of a forest mould, so essential to the best forest growth.

Forestry on unwooded, non-agricultural land presents another problem, that of solid tree planting, the treatment required depending upon the soil. Sandy, rocky, gullied or overflowed land each presents problems peculiar to itself, the variety or varieties to be planted requiring study and investigation. The harvesting and marketing of mature trees require attention. The study of insect enemies and fungous diseases will be necessary if a state-wide forestry policy is decided upon.

In all fairness it seems that an area as large as twenty-five per 
cent of the land of the state, which is not very productive, is of enough importance to be worthy of serious consideration. A tax exemption law of some kind for non-revenue producing forest lands and a system of insurance against fire are two very important factors to be considered. The government subsidizes men to raise sugar and cotton. It protects the infant industries, but it penalizes the farmer with a high tax when he wants to raise trees. It does seem to me that a movement should be started to exempt the land devoted to forestry from taxation until the trees come to an age when it will be profitable to $\log$ them. It might well be a real job for the State Forester to pass upon the condition of land that would exempt it from taxation. We must do something to encourage the planting of trees; it takes years before a tree arrives at a stage where any profit can be got from it, and in that time encouragement should be given to the possessor and caretaker of the trees.

I have lived my life near the Mississippi River, and I can remember a time when there was not an hour of the day but what great rafts of pine logs went down the river. This has all stopped. I saw the last raft go down the river. There were days when good white pine lumber sold for two dollars a thousand feet. There is a lumber yard near my home which was once prosperous. The man in charge used to be the yard boss, but now there are only two men there, the boss and another man.

Is it not high time that we did something on our own good land to supply the demand for lumber? We have heard considerable talk here that we must reduce the crop of corn. To me it seems that we must raise corn where corn can be raised. If it costs three times as much to raise corn in one place than in another, is it not good policy to use the land that cannot raise corn profitably for some other purpose? Fifty per cent of the corn acreage in Illinois is raised on land that never has paid and never will pay for raising corn. If we can devote that land to some other purpose, we will be better off. True conservation consists of putting land to that use for which it is best fitted and can be most profitably used. 


\title{
CAN ILLINOIS COME BACK AS A STOCK BREEDING GROUND?
}

\author{
W. S. Corsa, White Hall
}

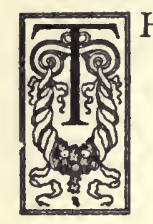

$\mathrm{HE}$ title of the topic assigned carries not only an invitation to a discussion of the problems of live-stock breeding in Illinois, but a challenge to her live-stock breeders as well.

We accept both the invitation and the challenge. We recall full well the outposts of the pioneers upon the prairies and the wooded grasslands of Illinois. The names of such worthies as Brown, Pickrell, Potts, Huston, Lovejoy, Dunham, Pierce, Goodwin, Judy, and the beneficence of their work descends to us as a precious heritage. Along with the inspiration of their example and accomplishment, we still have a notable membership of constructive, aggressive live-stock breeders, whose purposes, ideals, and methods are endeavoring to uphold the prestige and prosperity of our commonwealth. In this they are tremendously aided by-

\section{The Natural Advantages of Illinois for the Production of Live Stock}

Foremost among these natural advantages, as it appeals to me, is our wealth of limestone and its availability within comparatively easy reach of every farm. At moderate cost we can command this essential in live-stock production. With limestone in our soil to be transmuted through the chemistry of the crops into the bone and tissue of our live stock we may labor happily and confidently through the years, giving play to our fancy as to type; we can bank upon the results of our previous work; we can go forward unafraid that our soil conditions will crumble our efforts. If we obtain a desirable size in our live stock we can maintain it. We are free from this dread struggle which is ever present for the live-stock breeder over vast live-stock areas such as Canada and the Argentine. Illinois may always expect visits of live-stock breeders from those countries. The same compelling reason as theirs prompts many of our sister states to consider favorably Illinois live-stock productions, and this probably always will be so.

Furthermore the central location of Illinois may be counted upon as insuring constantly recurring visits of live-stock breeders from other states. The main arteries of transportation East and West, 
reaching into the great Southwest and to the North, pass through the gateways of our state. Men may readily come here upon special mission or stop in transit. Many a visitor has come to the live-stock breeding farms of Illinois direct from the central markets. It was convenient for him to make the trip from such a point. He handles live stock commercially in a large way, and he is in need of a bit of live-stock leaven. And yet at no other time and under no other circumstance would he have come to the Illinois farm. Proximity to the central live-stock markets is a natural and material advantage to breeders of purebred live stock fortunate enough to live and operate in Illinois.

Possibly a less tangible advantage, but nevertheless one of far greater significance and real value attaching to purebred live-stock breeding in this state, is the circumstance that Illinois is the home of the "International." It is unnecessary to dwell upon that annually marvelous exposition. When traveling in other states I have been repeatedly distressed to hear young men of eager enthusiasm regret, as under recent financial conditions, their prohibitive distance from this final court of adjudication of supreme live-stock merit. These men wonder that all inhabitants of Illinois interested in live stock do not always attend the "International." And the answer is that Illinois people, manufacturers, merchants, and mechanics, as well as live-stock men, are coming more and more by their presence at the "International" to sense the value of this rigid short course in livestock husbandry.

\section{Some Drawbacks}

With all of our natural advantages there are some drawbacks to be met in Illinois in the production of purebred live stock. Our state has no monopoly of these hindrances, which for the most part are simply useless and unnecessary drags upon our business and the prosperity of the state. It has seemed, and is still evident, that in Illinois there is a marked lack of esprit de corps among live-stock breeders. This lack is being overcome, in a measure, in state breed associations among the adherents of the various breeds; but this spirit is more or less absent among those interested in somewhat competitive breeds and it is notably absent among the supporters of noncompetitive breeds. The interest of the beef breeds in one another is that of mere decency, and possibly the same may be said of the dairy interests. The hog men have made marked progress in their get-together spirit; but the horsemen are tightening the traces of 
their own load, oblivious of the troubles of others. The fact remains that we are all part and parcel of the great live-stock industry of Illinois in which the human equation will largely delimit results for ourselves, for one another, and for Illinois. The area of Illinois is neither so great, nor is her heart so small, that she cannot successfully foster the sentiment of state pride among her children who breed and feed live stock.

The banker indifferent to live stock, and especially to purebred stock, has been found occasionally in Illinois. He is more frequently encountered in this state than in states farther west, where, in normal times, especially low terms and long-time loans are waiting for the man who is willing to undertake the improvement of the livestock population. Fortunately, however, a great number of bankers in Illinois have the foresight and vision to see, the end of the road of exclusive grain farming, or even of a live-stock industry based on scrub animals. It is not always the money of the banker that is wanted-in fact, it may not be desirable that the breeder should have it - but what is needed is an intelligent sympathy and understanding on the part of the banker which will make him able and willing to give counsel and, where advisable, to render financial help. The lack of this mutual confidence has doubtless been frequently responsible for individual disaster among live-stock men. And any great number of such occurrences in a community means one of two things: Either the community will settle down content with a very inferior and constantly deteriorating class of live stock, or its money will be constantly going away from home for such stock as it needs. The banker will be affected either way.

It is strange that the state policy of Illinois should not be clearly and at the same time generously defined relative to promoting its own welfare through the purebred live-stock industry. It is regrettable that some of its officers in the person of unwise assessors should officiously put the brakes on her welfare. Fortunately, however, for the state, many men of discretion and judgment acting as assessors recognize the great assessable wealth spread over the community through the enterprise and judgment of the purebred livestock breeder. It is plainly unfair and even folly to tax the price which a breeder may have wisely or unwisely paid for an animal. Purebred and registered live stock should be assessed in accordance with their merit in the regular tax classification. That is to say, if top quality milk cows are assessed at fifty dollars, then the individuals of a herd of purebred Holsteins or Jerseys should be rated at fifty dollars. 
A drawback to purebred live-stock raising in Illinois, as elsewhere, is the excessive transportation charge for purebred live stock in express and freight rates. It is necessary only to point out that the tariff is loaded with double and triple the weights of the actual animals, and that the rates are at the uppermost limit. It is noteworthy that in Canada, where the pure-bred industry is wisely cultivated, such pure-bred live stock may be transported at a reduced rate. In fact, on a recent shipment of horses from White Hall, Illinois, into Canada, the charge was as great to Detroit as to a point one hundred miles farther on in Canada, on a through bill of lading over the same road.

\section{Why Illinois Will Come Back}

The purebred business in Illinois is a going concern. That being a fact, the live-stock breeder is now finding himself fairly comfortably situated as to cost of production and the imminence of his market. It will be well indeed for the breeder and his community when they recognize their mutual dependence and benefit. Really the live-stock field in Illinois has only been summer fallowed. A greater market awaits the Illinois purebred live-stock breeder within the boundary of his own state lines than most men ever dreamed of acquiring. The saving in railroad fares and freights, the opportunity of inspecting the parent breeding stock and the farm practise employed, all will serve more and more to develop the home market.

In the econony of live-stock production our comparatively favorable rates to the central markets mean much. No breeder may hope to reach the high rounds who invariably sells all of his best productions. Again, no breeder who keeps all, or any great part, of his poorer productions may hope to accomplish any good for himself or his breed. The road for these poorer specimens to take, in ever increasing numbers, is to the central markets. Cull, eliminate, ship and repeat. Feed the best to the best and ship the rest. If this is the policy, then Illinois will come back and we will come back with her.

Indeed, Illinois must come back. Her present land values demand products of higher quality and value. The overhead of every farm-and this somewhat indefinite but very real item of expense is quite likely to grow rather than diminish-calls not only for economy of production, but for quality as well. Quantity in the production of live stock is not always a blessing. In fact, as has been well said, there may be a "curse of prolificacy." The female that with per- 
sistent regularity ushers misfits into the world should be discarded. The more of her kind we have the worse off we are, and the longer will Illinois be in coming back.

The higher quality productions demanded by present land values must be found generally distributed over our state in the form of high-grade herds, flocks, and studs; and this, not alone for the recompense which will warrant present land values, but for the maintenance of the life and health of our soil, our live stock, and our people. So, to some of us, it has seemed unfortunate that the attitude and teaching of our Agricultural College has apparently been misunderstood. Valuable as is the wonderful trinity of limestone, phosphorus, and legumes, it further requires the participation of live stock to form the four-square quartet that is the invincible basis of Illinois agriculture.

Among the agencies powerfully helping Illinois to come back in live-stock production is her College of Agriculture. Many friends of the College, recognizing the purity of her purpose in withdrawing the College team, some years since, from intercollegiate judging contests, are greatly pleased that she can now see her way clear to reenter the lists. We believe this will meet with the hearty approval of the live-stock interests of Illinois and go a long way toward helping Illinois to come back, through the awakened enthusiasm of her student body. Further, may I suggest that the good work of bringing the live-stock breeders to the College be supplemented by taking the College to the breeders. Some of the live-stock breeders of Illinois feel that today they have more friends among the under-graduates and alumni of our sister state institutions than of their own state Agricultural College. This is simply because, from time to time, delegations of such students from states-not in every instance, neighboring states-have repeatedly visited the live-stock breeding farms of Illinois. The breeder of purebred live stock appreciates the stimulus and encouragement which comes from the personal visits of the undergraduates and the instructors of the agricultural colleges, but more especially does he appreciate those from the college of his own state.

A very desirable contact is established between the breeders and the Agricultural College when it fosters state breed associations. The annual meeting of the Illinois Percheron Breeders' Association, just held here, reflects the steadying influence of the College through the quiet, thoughtful guidance of the State Association, from its organization to the present, by a valued member of your staff.

To aid her in coming back, Illinois has a new and mighty helper. $\mathrm{He}$ is full of the enthusiasm of youth, he is rich in the experience of 
the ages, his pleasure is in service to others. His name is "County Adviser." Selected and fitted for his work, from his youth up, by the Agricultural College, we can depend upon his energetic support of the higher and better things in Illinois agriculture. $\mathrm{He}$ is in almost every county, reaching to the uttermost township, encouraging the beginner, aiding the more experienced, organizing both for business. His intelligent direction of community effort is starting something. It is Illinois coming back. Already she is on her way. Illinois' pride in past performance, her natural advantages, her Agricultural College, the spur of her necessity, these will not completely bring Illinois back. In the last analysis, that is up to the men and women of Illinois. Illinois is relying today upon the love and affection of her children to bring her home. Her men, now as of old, are men of courage and of industry. They are not lacking in gratitude for the rich inheritance of a good name, and a fertile soil, and they pledge themselves to pass this on unsullied and unimpaired. They have the vision to know that changing times do not change the eternal principles of a permanent agriculture. They have faith to believe that the opportunities of that agriculture will come again-

"They do me wrong who say I come no more, When once I call and fail to find you in. For every day I stand outside your doorAnd bid you wake, and rise to fight and win." 


\section{THE OUTLOOK FOR LIVE STOCK IN ILLINOIS}

H. W. MUMFORD, Professor of Animal Husbandry, and Director of Live Stock Marketing, Illinois Agricultural Association

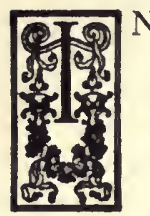

N THE agricultural development of the corn belt of the United States, Illinois early occupied a prominent place. In this development, live-stock production played an important part.

It is not my province to deal with the historical phases of live-stock production in the state; but for the purpose of obtaining a proper perspective of the outlook for the industry in Illinois it may be pointed out very properly that Illinois breeders and feeders have occupied for many years an important place in live-stock affairs. In 1860 Illinois ranked third among the states of the Union in the value of her live stock, in 1870 second, in 1880 first, and in 1900 dropped back to third place which position has been maintained.

The importance of live stock to the agriculture of a state, however, is not to be measured in numbers or even in value but rather by the contribution that live stock has made to its agricultural development. In the development of agricultural policies in the past too little consideration has been given to the various factors which have a direct bearing upon the development of particular phases of agricultural production, such as suitability of soil and climate, available markets, labor supply, likes and dislikes of farmers themselves, and in some instances, as in meat and milk production, the interdependence upon other phases of agricultural production.

Perhaps the most significant and encouraging sign in connection with live-stock production in the state of Illinois is the tendency to consider it in its national and even international aspects and to recognize it in its relation to the farm business as a whole and not as a more or less separate and independent unit of the farm business. The more persistently these considerations are kept in mind, the more wisely and more permanently will the animal industry of the state be developed and guided into the most logical and profitable direction.

\section{Factors Affecting the Future of Live-Stock Production IN ILLINOIS}

Most of the conditions that led to the prominence of live-stock production in Illinois in the past will continue to be determining 
factors affecting the future of live stock in the state. Some of the more important of these conditions are-

(a) The large production of corn and oats. According to the Census of 1920, Iowa and Illinois produced twenty-eight per cent of all the corn produced in the United States in 1919. These two states sold nearly half, forty-eight per cent to be exact, of the total corn sold from the farms of the country. Illinois leads as a cornsurplus state. In oats, Iowa and Illinois produced thirty per cent of the total produced in the United States and sold 45.6 per cent of the total. Iowa leads as the oat-surplus state.

The fact that Illinois is one of the leading corn-producing and corn-surplus states of the corn belt goes a long way toward determining the direction which live-stock production has and should logically take; viz., that type of animal production in which a relatively abundant and easily available supply of grain is essential. As examples of this type, we have meat and milk production in the form of beef, mutton, pork, poultry, and dairy products. The time will come if indeed it is not already here, when widespread, small-scale live-stock production as a conserver of grain-growing residues on most farms will not be despised. Every grain farmer is vitally concerned in the preservation of the live-stock industry. Under normal conditions approximately 80 per cent of the corn, 63 per cent of the barley, 39 per cent of the oats, and 12 per cent of the wheat is fed to live stock.

(b) A considerable area, approximately seventeen per cent of the land acreage in the state, is suitable primarily for pasture. If one will take the trouble to inventory the agricultural resources of the state suitable for live-stock production, he will find that there are in addition to considerable areas of land, very large quantities of feed that cannot be utilized advantageously in any other way. If the area in cultivation were increased to the highest possible state of intensity, there would be a decrease of the amount of land available for pasture but there would be an actual increase of available food for live stock.

(c) Illinois is favorably located with reference to the leading live-stock markets of the country. It is doubtless true that live-stock producers in Illinois are at a slight disadvantage, when it comes to buying corn for finishing live stock for market, as compared with some other corn-belt states. On the other hand, no other state is so favorably located with reference to nearness to the great live-stock markets of the country. 


\section{National Considerations}

In determining live-stock production policies for Illinois it is necessary to approach the subject from a national as well as a state standpoint.

Speaking generally, live-stock production has not kept pace with the increase in population. It might be expected that this growing tendency would bring about a shortage which would favorably affect prices of live stock in the markets of the country, and to such an extent that live-stock production would be stimulated. The fact is however that, disregarding the war period, the margin of profit in the production of beef, mutton and pork has been narrowing for a considerable number of years. In very many cases it has disappeared altogether, and not infrequently very large losses have resulted.

It is, I believe, literally true that one of the largest factors affecting live-stock production policies has been the fact that farmers find it increasingly difficult to make the finishing of beef cattle profitable. The anticipated shortage has failed to materialize, largely, it is believed, because of the falling off of our export demand for beef, due to the competition of Argentina, which has the advantage from the standpoint of cheapness of production. Similar analysis might be made of the mutton and wool industries. Looking forward, it is logical to anticipate that the competition in the meat markets of the world by such countries as Argentina, Brazil, Mexico, and South Africa will increase rather than diminish. Just what effect that will have upon live-stock production in Illinois and the United States should be given the most careful consideration. These facts are stated to emphasize the international aspects of live-stock production.

\section{Demand for Economy in Production and in Marketing}

No proper consideration of the outlook for live stock in Illinois can be complete without due regard to the trend of production and an examination of the causes of such tendencies. It is reasonable to conclude that in the main these tendencies are the normal result of changing conditions which are likely to continue to operate and which are certain to affect the agricultural policy of the state.

From the standpoint of the live-stock producer, any condition or circumstance which stimulates production abnormally, whether due to temporary high prices or to zealous advocates, is likely to be followed by disastrous results to the producer. On the other hand, depressing conditions which tend to large reduction in our flocks and herds, threaten the normal supply of meat and are therefore of con- 
cern to the public. It is therefore desirable that producers should as rapidly as possible approach an equilibrium in live-stock production, where the total production more nearly conforms to a normal demand for domestic meat products; and should formulate plans for the supplying of the markets with this live stock in quantities and kinds required. In this work Illinois will need to join with other states and act in harmony with them.

As this country grows older and the population becomes more dense, the demand for cheap food will become more intense. This means, among other things, that if the laboring man, who should always be our largest consumer of meat, is able to eat as much meat as the nature of his work requires, it must be furnished to him at a price that is reasonable in comparison with other foods.

This fact alone will force the practise of the greatest economy in the production and distribution of meat. Already there is no possibility of the producer securing adequate profit in the production of live stock by following wasteful methods of production. In order that the producer may receive the full benefit of a normal demand for his product, the costs of marketing and of the distribution of meats to the ultimate consumer are in importance second only to that of economical production.

Much work has been done to improve methods of maintaining, fattening, and breeding of beef cattle. There still remains much to be done, particularly with reference to establishing rather definitely the place of the beef cow and the steer in systems of farming adapted to Illinois conditions.

\section{The Dairy Problem}

The live-stock problem as it relates to beef cattle and to dairy cattle seems to be different in some respects. The community and the individuals in a community who are in the dairy business are more prosperous if they do not depend alone on milk production for their profit, but on the selling of improved live stock as well as milk. That is, the successful dairyman must be a breeder of dairy cattle as well as a producer of milk. This applies as much to grade cattle as to purebred cattle.

The man who approaches the dairy problem from the standpoint of raising dairy stock both for his own future herd and also to sell, requires a higher degree of intelligence. The production of milk alone as a source of income tends all the time to give inadequate attention to the health question of the cattle. Whereas the man who is breeding his own cattle for a future herd, expecting to get a part of 
his income from the cattle he breeds as well as from the milk, finds it necessary to look after the health of his cattle, so the whole health problem is involved in that system of dairy farming.

It appears that the more prosperous dairy communities are those in which this dual-purpose is the aim of the individuals in the business. Such a system of dairy farming in any community or around any center will tend also to a more even supply of milk. The dual purpose in the dairy business leads to efficiency in production because the breeding of better dairy cattle leads to the production of a more efficient cow, cheapens production, and increases profits at the same time; while the other does not necessarily tend that way.

The future of dairying in Illinois will be very directly affected by the improvement in the milk marketing situation throughout the state. More attention should be given to developing a market that will recognize quality in milk.

The kind of dairy farming referred to does not confine itself to milk production, because the sale of cattle is another profitable phase of the industry, and there is a marketing problem in the sale of cattle as well as in the sale of milk. It seems, therefore, that the prosperity of the dairy industry hinges upon a better marketing plan both for milk and for dairy cattle. In the marketing of dairy cattle the thing that we need to improve, in order to make that end of the business prosperous, is the health of the cattle; and then we need to establish a reputation that is comparable with the health and quality of these cattle.

\section{The Place of Other Live Stock}

Not even a brief discussion of the future of live stock in Illinois would be complete without recognizing the very large place that swine will most certainly occupy. In this, as in all other live-stock enterprises, new problems are constantly being presented; and upon the satisfactory solution of these the future of the industry will depend. Swine diseases, and the most profitable type of hog for corn-belt farms, are among the problems requiring the most thoro study.

The poultry industry, the importance of which in this state is not generally recognized, will more and more force its claims upon the consideration of producers and the public. It will not be unexpected if this industry records a very marked development in the state during the next ten years.

I can see no good reason why the business of finishing and fattening sheep and lambs for market and, at the same time, the keeping of small farm flocks, should not be extended in this state. 
The horse, so recently threatened with banishment from cornbelt farms has demonstrated that he still deserves a place on every farm and for short haul work in cities. The location of the state, and the long years of successful experience of Illinois farmers in horse production, point to the conclusion that there should be some profit to a community in producing its own work stock, with possibly some surplus to sell.

\section{Future Lines of Development}

Broadly speaking, it is difficult at a time when agriculture is in such a disturbed condition as it is at present, to forecast the future of live stock in Illinois. Notwithstanding this, it is all the more desirable to take a forward look and indicate along what lines our thought and action should lie, keeping in mind that some of our conclusions will most likely need revision as the agriculture of the country returns to a more normal state.

More economical production may still be effected as a result of further investigations in animal breeding and feeding.

In the selection of breeding stock of dairy cattle, meat animals, or poultry, we follow rather blindly the traditions and standards handed down to us from the past, without much knowledge, except in dairy cattle, whether those standards are justified by the capacity of the animal to produce economically. A thoro testing of present standards for the selection of animals for various purposes such as meat, milk, and work is sorely needed. Not much progress has been made in developing practicable methods of measuring the efficiency of breeding animals of the meat-producing types.

There is need for a greater degree of independent thought and action among live-stock breeders. Perhaps to too large an extent have breeders silently submitted to the fixation of types in our breeds by individuals and groups whose chief thought was more the commercialization of an idea than its utility. In general, live-stock breeders, while displaying great skill in the development of animals to meet the standards of the show ring, have lacked courage in giving proper recognition to the development of breeding animals with the usefulness of the animal in the every-day economy of the farm primarily in mind. It is to be hoped that this will be one of the significant developments of the next twenty-five years.

The development of disease resistant strains, within our improved breeds of animals, offers a fertile field of inquiry. 
When it comes to practicable methods of extending the influence of better live stock throughout the state, a further development of community live-stock breeding projects gives much promise.

A large field is still open in the direction of research. Studies should be conducted to ascertain the energy requirements of sheep, swine, and horses; the factors which modify these requirements, particularly the age of the animal, its size, condition, and the atmospheric conditions; the efficiency of the horse in the performance of different kinds of farm operations; and the efficiency of the conversion of the energy of feeds into meat, milk, and work, particularly as affected by light, medium, and heavy rations.

The fact that the future of live stock in Illinois will to a large extent be shaped by the agricultural policy of the Nation, particularly of the corn belt, and by the larger movements in agricultural production in the world at large is unescapable. Because so much depends upon what the state as a whole, the Nation, and the world at large are doing, the largest possible assistance should be extended in the development of plans for securing such information and making it generally available for live-stock producers.

In helping to solve the various problems arising out of live-stock production, large use of economics will be required. Not only should the most thoro research in agricultural economics be encouraged, but also it is particularly important that agricultural students who are to be the leaders in agricultural thought in the state should be well grounded in the principles of economics. We must learn to fit our live-stock operations into systems of farming so that they will utilize, not only our surplus, but also the by-product feeds of the farm, which would otherwise ordinarily go to waste. We must not allow our live-stock operations permanently to take out of the cropping system land that can better be utilized for grain production. In other words, any attempt to preserve a phase of agriculture when its preservation is uneconomic is a short sighted policy and indefensible.

In our zeal to make the greatest possible use of this field of study it is not necessary that the sense of proportion with reference to other fields of study should be lost. The question resolves itself rather into extending our lines of study, and to utilizing economics in attempting to interpret and to gain a better understanding of the relation of the various phases of agriculture, and indeed of the relation of agriculture to other industries.

No other institution is in as strategic a position to give proper direction to the future of live stock in Illinois as the University of 
Illinois. It is of the utmost importance that the teachings of the Agricultural College, the agricultural research of the Experiment Station, and the work of the Extension Service should all materially contribute to the proper development of the live-stock industry, and that none of these should fall into the very natural error of the specialist of viewing agricultural problems primarily from the point of view of the development of special phases of agricultural production. In determining a proper agricultural policy for the state of Illinois, live-stock production should occupy an important place because without large live-stock holdings it is impossible to secure the largest utilization of all the agricultural resources of the state. 


\title{
ROADSIDE IMPROVEMENT
}

\author{
W. N. Rudp, Blue Island
}

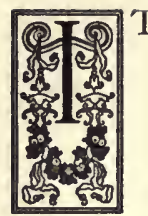

T IS perhaps hardly twenty years ago that in writing a paper on this subject for presentation before almost any audience in our state, one would have been pessimistic as to its reception, almost certain that it would not be considered worthy of serious attention; perhaps well enough for the women to talk about, along with their posy beds, but nothing for a hard-headed, upstanding, two-fisted man to waste time upon. The writer would have felt it necessary to devote half his space to special pleading, in a timid way, for a hearing, and the balance largely to showing how little really need be done and how very, very cheaply improvements could be made.

Today, there is not one person present here who does not realize fully the great importance of banishing from our homes, and from the surroundings among which we do our work, all that we can of the ugly and unsightly; and of bringing in all that may be possible of the sightly and the beautiful-importance, mind you, not only on the esthetic side but on the cold, hard, dollars and cents side also; in the proved increase in our property values, in the better output of labor when we are working in pleasant surroundings, in the greater happiness which will keep more of our young people at home, and in the increased traffic attracted by beautiful drives and the increased business which it brings to our neighbors who are makers and sellers of things needed or desirable. We can approach the subject confidently today, as one of accepted importance, without necessity of excuse, apology, or special pleading. Our problem now is not whether to do, but what to do; and how, when, and where to do it.

It is stated on apparently good authority that there are 96,000 miles of public highway in Illinois. Those who are so minded may find interest in estimating how many times these highways, if continuous, would go around the earth's circumference and how many trees it would take, if planted fifty feet apart, to border each one of them on both sides. Truly, in the light of these figures, our subject becomes a very big one indeed. We have no need to be discouraged at the magnitude of the task, however. It will be spread over many years to come, and we and our children and our children's children will all be working at it.

The work divides itself naturally into two lines: first, to do away with the ugly or unsightly, so far as we can; second, to add 
such elements of beauty as are found desirable and feasible, after a careful study of topographical, climatic, and soil conditions, economical first cost and, especially, cheapness of maintenance. Above all, we must ever have in mind that a road is built for a very real and a very definite purpose of use, a supremely important use; and we must not in our work either take away or add anything which will, in any serious degree, prevent the most free and the fullest use for which the road was built, or interfere with the facilities which it was intended to furnish.

It is a fundamental principle of decorative art, perhaps the fundamental principle, that any attempt to embellish, or to ornament, or to beautify a thing intended for use, which results in rendering that thing less useful or less easily used, is bad art-always and everywhere. Confidentially, and "mentioning no names," the application of this test of true art to certain buildings in a certain one of the world's great universities, might reveal some art that is-well! not good. But that's another story.

The first line of work, the removal of unsightly things, is easy to carry out. The greater part of the unsightly things are left or placed in the highway or near it by thoughtless or careless persons. Persuasion and the arousing of public sentiment will secure the removal of the unnecessary and the repair of the dilapidated. The expenditure of money in this connection will rarely be needed.

Perhaps the most difficult of all the ugly things along the highway, to handle, are the billboards generally erected in the precise location where they may destroy all pleasure in the finest view, or most effectually exasperate the lover of Nature's beauties. The National Civic Association is conducting a campaign against them, and has issued bulletins covering the matter very thoroughly; so that nothing need be said at this time, except the suggestion that a drastic license fee might be imposed, increasing with the size of the board, and a little neighborly remonstrance exerted with the owner who allows his land to be used, or his buildings to be defaced, for such purposes.

The growing custom of erecting advertising signboards, masquerading as directing or distance signs, should be checked. It is entirely within the powers of highway officials to remove them and to prevent the erection of others. An aroused public sentiment is the remedy. The rural mail box is a necessity, but the straggling groups of them 
looking like groups of drunken sailors at almost every junction of our country roads should not be permitted. The highway officers have full power to designate places for them and to require their erection and maintenance in a proper, orderly, and sightly way.

The nailing of signboards and political and other notices to trees, telegraph poles, and fence posts need not be permitted. Public bulletin boards of unobtrusive size might well be erected at selected locations and their use allowed on permits, possibly after the payment of small fees sufficient to provide for their erection and maintenance. The many other small nuisances will, in most cases, each suggest an obvious and ready way for its abatement.

The lines of telegraph; telephone, and electric light poles are unsightly things which we cannot at present do away with, but we can at least require their being maintained.in a neat and upright position and prevent the unsightly bracing' we so often see applied to weak or improperly set poles. The tree mutilation which so frequently accompanies the operation of such lines is a crime, to the lover of beautiful trees. The courts have allowed punitive damages to the owners of adjoining land who have planted the trees, in such cases; and it is perfectly feasible for public officials having jurisdiction, to prosecute and punish such offenses.

In one Canadian province, at least, the pole nuisance is being minimized by increasing the width of main highways from sixty-six to eighty-six feet, placing the poles outside the trees in the added strip of ground, thus rendering them less conspicuous and much less likely to interfere with tree growth. Our Illinois country is much more thickly settled and our farms of much greater value, so that, except in unusually favorable locations and for short distances, it wotld not seem feasible to adopt this desirable practise in our state.

So much for the negative, the easy and the obvious part, of our great task. The other part, the constructive part, is not by any means so simple a thing. It is always easier to tear down than to build, always easier to take a blemish out of a picture than to create the picture.

We are to be makers of beautiful pictures just so truly as the painter who works with his oils and his colors on the flat canvas. Our colors are the trees, the shrubs and the flowers which we use. The painter's colors dry to their final hue tomorrow, or next week; ours, not for a generation or more. The little saplings which we plant today will not fill the space we have planned for them, nor give the ultimate effect desired, until, perhaps, after we are dead and forgotten. We seldom see the finished result except in our mind's eye. We shall therefore be wise if in doing this work we obtain the 
advice of those who by long study and varied experience can direct with a sure eye and a competent hand.

Our state, as you know, is a land in large part of flat level prairies and our roads, often for mile after long mile, run straightaway without turn or curve and without appreciable rise or fall. Our present accepted hard road construction is an eighteen-foot streak of gray or almost white concrete, stretching away miles beyond all possible range of vision; mathematically exact at its edges, never widening, never narrowing; and then the fences equidistant on each side, wire and posts, wire and posts, and more wire, and more posts, posts without end; and we begin to understand what Kipling's soldier felt with his

Boots, Boots, Boots, Boots,

Slog, slog, slogging up and down

and we try to make a little rhyme to match it beginning-

Posts, Posts, Posts, Posts,

and we can't do it because rhyming is neither our trade nor our profession. And there is your Illinois road for many miles, in many parts of the state, and there is your problem, to take the curse off of it. It is a most difficult one to solve; but we can be thankful that few, in fact none, of the others are so difficult. It can be solved; all problems can be solved, except, possibly what to do with our telephone poles.

The person who has given little study to the question will be quite apt to say, with conviction: "The whole problem is a simple one. Plant trees. Plant them on both sides of the road. Plant them by the thousand. You can't have too many trees. What is more beautiful than a fully developed maple or a perfect, mature elm? What greater delight than to drive under the cool shade of their over-arching boughs, sheltered from the scorching sun of a July day?" Ah! But after July and August come September and October, and the winter months and then spring. Only a small part of our days are July days. We must have variety. We must have delights for all days, not July days alone.

I can conceive of nothing more monotonous than an endless ribbon of gray road seen through a never-ending arch of green boughs, except, possibly, the same road without any trees at all. No! It would be deadly monotony and our traveler would again be at his rhyme, only instead of posts, it would be Trees, Trees, Trees, Trees. We must have variety and change. We must have ever new and different beauties. We must not shut out the beautiful distant views. 
We must have open spaces where the large trees give way to masses of shrubs and groups of the smaller native trees and their fall coloring of foliage and the winter berries and colored bark. There must be places where there is no planting at all, to distract the eye from lovely distant views. There will be a few groups of the hardier flowering plants here and there in the open; not too many, because their lives are short and their upkeep expensive. There will be many noble avenues of trees, and let us hope that we may be able to widen the roadway along those avenues. There will be isolated specimen trees. There will be trees planted in groups; trees in rows on one side of the road only. There may be wooded areas adjoining our roadway which can be acquired cheaply and through which winding, unpaved summer drives may be opened to tempt the traveler off the beaten track. There may be adjacent swampy or wet areas of little agricultural value which will lend themselves finely to a very different style of planting. Perhaps we may find cheap areas at the intersections of roadways where planting may be done in a parklike way and thus improve two roadways with one planting expense.

We have thus sketched hurriedly and most imperfectly plans which if carried out in spirit would make the highways of our great state an inspiration and a delight to all people, to the traveler from other sections, to the busy man journeying on his daily affairs, to the children on their walks to and from school, and to the whole family on its way to church.

Mention of our schools and our churches brings us squarely up against the fact that these two institutions, alongside our roads, are in general the greatest offenders in the length and breadth of Illinois in the way of maintaining unbeautiful and even positively ugly conditions in the grounds surrounding the buildings which they occupy. The old Puritan idea that religion is an austere and an unlovely thing has been cast aside and we now believe that religion is most beautiful in all ways. Why then should we not surround the edifice where we go to practise its rites with all the beauty that we can reasonably give it? Why should not every schoolyard be planted with flowers and flowering shrubs and these young, plastic minds taught to love such things, and how to cultivate and protect them? Why should not they be taught to protect our beautiful wild flowers; to pick them, when really desired, carefully and with moderation, instead of ruthlessly dragging them out of the ground, roots and all, by arms full, to be carried for a little while and then thrown aside that more may be pulled up and destroyed? 
It can all be done so easily and so cheaply, although we may have to go among those who are training our teachers and drive out some of the worship of teaching methods and drive in a little more attention to what to teach. We can well do with a little less of George Washington, and Raphael, and Leonardo, and with a good deal more of Daffodil, and Primrose, and Columbine.

Granting the extreme desirability, the almost necessity, of the roadside improvements we are advocating, the question then comes, "What of the cost?" With economical and careful planning, the ultimate cost can be made astonishingly low. One one-hundredth part of what we are spending for hard roads would enable us to accomplish wonders in improving those same roads; and the work need not be done all at once, but could be spread over a number of years, making an absurdly small annual charge.

The elimination part of our programme could well be carried out by small groups of people working in their home localities. The constructive work could better be handled by larger organizations, perhaps county-wide. The work on the state-maintained roads might well be centralized in a group closely allied to and functioning with those in charge of the maintenance of those roads. Friction and overlapping authority could thus be avoided, and greater economy in both our construction and maintenance be attained. 


\section{THE COUNTRY HOME}

\section{J. V. Stevenson, Streator}

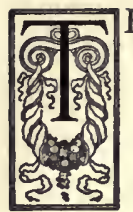

$\mathrm{HE}$ future of our nation depends upon the kind of citizens that we produce. In turn, what our citizens are depends very largely upon the homes they come from, so I take it that it is in this light that we are interested in discussing the country home today. The statement has been made often, and needs no proof here, that the most of our leaders in thought and action have come at some time from the farm. This has been true all through our history, from the days of the log cabin country home down to the present time. We are constantly drawing on our rural population for new blood, in government, in business, in all the professions. And it is this steady stream of new blood, pure, virile, and one hundred per cent American, that has enabled us to forge ahead and assume the lead among all nations.

\section{Citizens in the Making}

What is it, then, in the training and home life of the country bred citizen that gives him this virility and dependability so essential to success? We might mention first the influence of pure air, pure food, of quiet and natural surroundings and plenty of sleep. These help to develop our country children into better "animals." A sound body and a sound mind make up a useful combination. Without either a person is out of balance and his usefulness is impaired.

Closely related to this matter of good physical development is another point in favor of the man or woman reared in the country. Almost from the time the child is able to walk it begins to learn something about work. The little girl four years old can help her busy mother in many ways; the boy of the same age loves to follow his father around while he is doing the chores. And he too, very early finds things that he can do to help, and ways in which he can save his father a good many steps. While the little tots are thus saving their parents a good bit of energy, the effect on the children is of vastly greater importance; for they are learning to work. They are learning that there are things to be done every day and at certain times of the day, and that if these things are not done at the proper time more or less serious consequences will result.

A little later the child goes to school. Before and after school the city child has nothing to do but play. The father is busy at the office 
or the store or the factory. The mother is frequently also busy at the club or the shops or the matinee. The child is left more or less to his own devices, and he plays with his school friends, often in the street or alley, having no other place to play. Here schoolboy "gangs" are formed. Here he learns every form of meanness that boys know, and very frequently right here is planted the seed that later develops into the hardened criminal. The country child, on the other hand, has his chores to do both morning and evening. The woodbox must be filled, the chickens fed, the eggs gathered, the cows milked. Those chores are just as much a part of his day's routine as eating his three meals or going to bed at night. So, while his city cousin is playing with the gang in the street or going to a movie or otherwise offering a fertile field for Satan who "finds mischief for idle hands to do," the country boy is keeping his hands busy doing useful work, and what is more important, is forming the habit of doing things on time.

Another point in favor of the country child's training is that he knows nature and learns to distinguish between the fundamentals and the non-essentials of life. To him clothes are incidental, and the tricks of so-called polite society are unknown. But he knows how things grow, and he knows something of the relative value of the things that we eat and wear and work with. The city boy of twelve probably knows the latest fashion in clothes, the latest fad in haircuts and the newest song hit on the street. But in many cases he does not know whether potatoes grow on trees or bushes, whether some of the cows give buttermilk or whether we "keep a bee" to furnish the honey for our table.

\section{The Farmer's Life an Open Book}

There is one feature of the farmer's business that has an important effect upon his home life and his moral development. In his business there is little chance for concealment or deceit. While the work of others may be surrounded with considerable secrecy, which may lead to misrepresentation, the farmers' business is always open to inspection. He cannot hide his fields or his stock from his neighbor's eyes. So, while the business man may talk in terms of many figures and may contrive to make his business appear much more important than it really is, it is a comparatively easy matter for any farmer to know in a general way what his neighbor is doing in any of his productive enterprises. When a man's business is thus open and above board, it is reflected in the character of his home life. He is a better husband, a better parent, a better citizen. 
And this leads me to what is perhaps the most important factor in this development of citizenship in the country home. It is the sympathetic relationship that exists in the farm family. Three times a day the whole family gather at the table for meals. All of them know what the others are doing and they are interested in talking about the things that affect the whole family. In the evenings, after the work is done, again all enjoy this companionship, lying on the grass in the yard to cool off on summer evenings, or sitting by the fire in winter with popcorn and apples and books and music.

What sort of place is this country home that offers so many advantages for the training of citizens; where shall we find it and how may we know it at sight? I would say that it will be found surrounded by evidences of good farming. We may expect to find good barns and outbuildings of all kinds kept well painted, a silo, good herds of well-bred live stock kept in by good fences, land well tilled and crops well diversified and with evidence of a careful conservation of soil fertility. The dwelling will be of permanent construction, will be designed to harmonize with its location, and will be surrounded by a grassy lawn with enough shade trees and simple landscape planting to make a good play ground for children and a pleasant resting place for grown people. Inside the house we may expect to find modern conveniences, including a bathroom, modern heating system, electric lights, mechanical laundry equipment, comfortable furniture, a piano or a phonograph or both, and many good books and current magazines. This is the kind of country home that in this twentieth century will induce companionships within the family, develop in children a love of farm life, bring out the best there is in them, physically, mentally and spiritually, and give them a memory of home to cherish always.

\section{How Far We Are from the Ideal}

I wish I might stop here and say that I have described the majority or even the average of farm homes in Illinois. If that were true we need have no concern about the future of our agriculture. Unfortunately it is not true, for so far in our development we have built very few permanent farm homes. The great majority of them have been merely dwelling houses built only with the idea of furnishing the lodging facilities necessary to carry on the farm business. But the time is coming, and it seems to me that it is not far distant, when we shall realize that the farm home must furnish more than lodging. It must furnish comforts and conveniences that will make country 
life satisfying and efficient. There are many farmers in Illinois today who can build such homes as soon as they make up their minds that they want them. To those I would say that I believe there is no other way that they can buy as much satisfaction with their money as in building an up-to-date, permanent farm home. There are very many others who want such homes, but have not the means to get them, and it is their case that I wish to present in this paper.

Take first the case of the tenant farmer. In some of our richest corn-belt counties seventy per cent of the farms are operated by tenants. Now there are some tenant farms where the home very closely approaches the ideal, but they are rare. In the majority of cases the owner is interested only in taking as much as he can from the farm every year. He has never realized or considered the importance of preserving the fertility of the soil. His business has been to mine that fertility just as rapidly as possible. Likely he lives in a distant city, perhaps in another state. Possibly all the business is handled through a third party acting as agent. In any case there is little or no thought given to the matter of making the place attractive or homelike. The only improvements made are those that are considered necessary to make the farm workable and to insure the landlord his rent from year to year. What is the result? A farmstead consisting of a little cluster of cheaply constructed and unattractive buildings, set very likely on the bleakest, most desolate part of the farm, with very few trees for shade and comfort and no grassy lawn for children to play in. No good live stock; because the landlord won't build barns to house them, and won't allow land sown to clover or other hay or pasture crops to feed them. Constantly diminishing yields, because the landlord can't see far enough ahead to provide for maintaining the fertility of his soil. Can you imagine children growing up in such surroundings with the desire in their hearts to be farmers? Is it any wonder that they flock to the cities as soon as they are free to shift for themselves?

\section{What IS THE REMEDY?}

What is the remedy? A step in the right direction will be taken when landlords stop renting from year to year on a single year lease, and adopt the long term lease, making provision for live stock and soil fertility requirements. This will make life seem more worth while to the tenants, will make them better farmers, better homemakers, better citizens. Some landlords argue that they cannot get 
tenants to whom they are willing to rent the place for more than one year at a time. To them I would say that if such a condition exists, it is a strong argument in favor of restricting the amount of land that can be held by an absentee landlord. There has been considerable agitation about this matter and much argument on both sides. It seems to me that we must agree that better homes and better citizens are the rule on farms operated by the owners than on farms which are part of large holdings belonging to absentee landlords. If the state is interested in having better homes and better citizens, and if we agree that these are encouraged by the pride of ownership, certainly we should welcome a law placing a reasonable limitation on the amount of land that any man might own unless he worked it himself.

But merely passing such a law will not get us very far in the solution of this problem. We must provide not only for the sale of part of the landlord's holdings, but we must provide also for their purchase by the tenants. And this is by no means easy under present conditions. A tenant, or any one who desires to buy a farm, may do so if he has accumulated approximately half the price. The other half can be borrowed by giving a mortgage on the land as security. Under the old system of borrowing from mortgage brokers, a mortgage on a farm for half the purchase price is by no means to be lightly considered or carelessly contracted. Such loans usually run for five years. Within that time it is very often impossible for the young farmer to pay any considerable amount. Then there is hanging over him all the time the dread of this mortgage, the knowledge that on a certain date it will be due, and the fear that he will not be able to renew the loan, or will be required to pay a generous commission to the agent who handles it. Instances are known where the commission charged for obtaining a loan of this kind was equivalent to one year's interest. Hence the traditional dread of mortgages, and the plan followed by so many farmers of skimping and scraping and slaving during the best part of their lives, and sacrificing education, culture, physical comfort and even health, in order to get out of debt. We need not be reminded that real homes cannot be developed under these conditions. In many cases these farmers and their wives not only spend the best part of their lives trying to pull out of debt, but they come in time to develop a habit of scraping and saving to pay off mortgages, a habit that they never overcome. They start out to pay off on their farm that they may have a home free of encumbrance. It takes all they can save to do the trick. There is nothing left for even the ordinary comforts of life. When the farm is finally paid 
for, they mortgage it again to buy more land in order to be sure to have enough for a "rainy day." And early training has instilled in them such a fear of mortgages that they continue to deny themselves the comforts of life until they are all paid out. Often this goes on and on until several hundred acres of land have been acquired. Then, realizing that they are growing old, they decide to build a modern home and enjoy life. But it is too late. The early habits have become fixed. They may build the finest house in the community, and surround and equip it with all the conveniences that money can buy. But they cannot be happy because they do not know how to enjoy these things. All their lives they have thought of nothing but saving money and in so doing they have stunted their intellects and souls so they will be miserable for the rest of their days.

\section{Our Limited Credit Facilities}

The Federal Land Bank and the Joint Stock Land Banks go part way in the solution of this problem. They loan to the purchaser of land up to fifty per cent of its value in most parts of the country. They furnish a loan that never comes due. By means of the principle of amortization the borrower makes a nominal payment every six months and in thirty-three years' time both principal and interest are completely paid. The old dread of the mortgage becoming due is removed. The borrower feels better able to invest part of his income each year in things that will make his farming more efficient and his life more satisfying. Among these things he will include the improvement of his home. He feels free to give a little time and thought to reading, music, and various forms of culture that make him a better home man and a better citizen.

But what about the young couple who want a farm home and don't have the fifty per cent for the initial payment? The Federal Land Bank cannot help them. There is no way for them to buy a farm unless they can find some good friend who is financially able and willing to loan them the other half of the price either on their personal note or with a second mortgage as security. But in the majority of cases such a friend cannot be found. What, then is the result? They must start out as tenants, probably on a farm that they can never expect to own or to make their permanent home. And you need not be told that it is a long and hard pull for them to get enough money ahead to make the initial payment on a farm. Not only is it a long and hard pull, and one that takes the best part of their lives in doing, but in the great majority of cases it is work done on a farm 
that they can never expect to own, and is accordingly time wasted as far as building a real home is concerned. Surely one of the most urgent matters before the country today is that of providing some sort of credit facilities for the young farmer and his wife starting without capital in order that they may get started at once toward making a home of their own.

\section{Better Credit, and Then-}

But again we must realize that even this will not take us all the way. A good farmer remarked just recently that to be able to borrow money is important, but to be able to pay it back is more important. Certainly we need better credit facilities for farmers, but just as certainly we need a better assurance of being able to pay out. For pay day always comes, and it is hard to see how the farmer can afford to pay six per cent interest for money to invest in a business that does not yield that much in returns. And we must face the fact that even with pre-war price relations reestablished, the average farmer cannot buy corn-belt land, equip and farm it, and make six per cent on his investment after paying wages, taxes, insurance, upkeep, and living expenses, not to mention wages for the work done by his wife and family. Now if it is going to be necessary for the farmer to deny himself and his family all culture and even the ordinary comforts of modern life to make both ends meet, we cannot hope to build a very great number of permanent homes in the country, and we cannot expect to keep our best young men and women on the farm. If it is worth while to give a college education in agriculture, that education should fit the student for life on the farm. For not all of our graduates can spend their lives in research or teaching or extension work. And in just so far as the products of our agricultural college will go back to the farm to put in practise the principles they have learned here, in just that measure will the influence of the college grow and strengthen our commonwealth.

But it is commonly said that a college education trains the boy or girl away from the farm. And in a measure this is true. Four years here at college have accustomed them to conveniences and comforts that they have never had on the farm. Not fine clothes and elaborate furniture and gay society, but things that are coming more and more to be regarded as necessities of life. Running water, good lights, mechanical laundry and cleaning equipment, music and books and, what is just as important, a little time to enjoy them; a home and farmstead built to harmonize with its surroundings and furnish 
an attractive place to live, these are the things that are more and more going to be demanded of the farm home. And no matter what other advantages farm life may afford, we cannot hope to see our best young men and women stay on the farm if they are denied these comforts. Just recently, I heard an old farmer who has spent all his life in hard work and who has never had the advantage of higher education or modern culture, say that he thought often when a farmer comes in hot and dusty from a hard day's work a good shower bath would do him more good than his supper. "And yet," he said, "the farmer is in the most part denied this comfort which is commonly available to the factory workers in our cities." Now we agree, and others are coming to realize, that farming is the biggest business in the nation today. Such a business demands that a great many of our best young men and women stay on the farm. Let me repeat that not many of them are going to be willing to stay there if they must deny themselves the common comforts and conveniences of daily life that are enjoyed by the average resident of our cities. Surely we must have in the country more real homes, homes that are not merely divelling houses but homes that provide the advantages that will make country life attractive and will give to our future citizenship the greatest possible development.

\section{The Lord Helps Them That Help Themselves}

How is this to be brought about? I should say by the farmers themselves. The main thing needed is to make farm business more profitable, to make farm returns somewhat comparable to the returns of other industries that require a similar investment and corresponding ability. Before we can build many permanent country homes, our farm business must be made to pay a fair rate of interest on the necessary money and time and ability invested. This cannot be brought about by any special governmental concession or guarantee, but a great deal can be accomplished by the farmers themselves.

Much can be done in this direction by the use of better systems of farming, systems that will enable the farmer to produce more efficiently and at lower cost. This is a matter of education and I believe our research and extension activities should continue and be further developed along this line.

But better farming cannot do it all. We must realize more and more that our business does not stop with production. We must pay more and more attention to the economical marketing of our products till they reach the consumer's hands, in order that we, as 
well as the consumer, may benefit by more efficient methods. This is a job that no farmer can do individually, but we are just beginning to learn that we can do it by organization. Not only through cooperative marketing can organization help us to a better return for our investment, but through organization and in that way alone, can we bring our case to the attention of the general public. Through organization farmers can meet around the council table or in legislative hall on equal basis with capital and labor, and thresh out such questions as taxation, transportation, and finance, that are vitally connected with the matter of income.

Now these cooperative organizations in order to be successful must have the right kind of leaders. These leaders must have a technical knowledge of agriculture. They must have a knowledge of the principles and methods of cooperation as they have been worked out through experience in this and other countries. And they must be instilled with the idea of giving service to their communities. I believe the University should give attention to the special training of men to be leaders in these cooperative organizations. The statement may seem far-fetched, but I believe it is true, that one of the greatest contributions the University can make to the development of the country home is the training of the men to be leaders of farmers' cooperative movements.

In closing let me repeat that we can hope for better country homes only when the business of farming becomes more profitable. The farmer has it in his own power to bring this about, first by his individual effort to produce more efficiently, and secondly by his organized effort to market more efficiently and use his influence toward a fair solution of our state and national problems. I have said that these farmers' organizations must have wise and well-trained leaders. Their success will depend ultimately, however, upon personal interest and activity of the individual farmer. If, through lack of interest, he allows his organization to be controlled by a few men with selfish personal ambitions, or allows it to degenerate into a paternalistic scheme supported by government funds, it will fail. In my humble opinion nothing in recent years, if indeed in our whole history, has dignified agriculture as an occupation so much as the growth and work of our farm bureau organizations. And this is true because the organizations were built by the farmers themselves. Therein lies the hope that we shall eventually solve our problems as they come to us, including the problem of the country home. 


\title{
PHYSIOLOGICAL BASES OF CROP PRODUCTION
}

\author{
W. L. Burlison, Professor of Crop Production
}

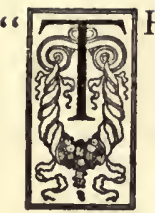

HROUGHOUT all ages the growth of plants has interested thoughtful men." "The beginning of plant culture goes far back into history." "The mystery of the change of an apparently lifeless seed to a vigorous growing plant never loses its freshness." And it is evident, too, that as time goes on and the world's food problem becomes more complex, this interest will steadily develop.

A review of some of the world's literature relating to agriculture reveals many interesting statements. It was thought by some gardeners that the moon exercised a controlling influence on the growth of plants. Others thought that the ruling force was an unknown God whose power never could be known. Before the advent of the fifteenth century, speculation and superstition ruled supreme. Since about the middle of the fifteenth century, plant culture studies have passed through certain rather well defined epochs, each in turn contributing valuable information and thus enlarging and enriching our knowledge of how plants grow.

\section{The Search for the "Principle of Vegetation"*}

Almost five centuries ago, Palissy said: "You will admit that when you bring dung into the field it is to return to the soil something that has been taken away. When a plant is burned it is reduced to a salty ash called Alcaly, by apothecaries and philosophers-every sort of plant, without exception, contains some kind of salt. Have you not seen certain labourers when sowing a field with wheat for the second year in succession, burn the unused wheat straw which had been taken from the field. In the ashes will be found the salt that the straw took out of the soil; if this is put back, the soil is improved. Being burned on the ground it serves as manure because it returns to the soil those substances which had been taken away." These facts have been confirmed in part from the study of chemistry.

Early in the sixteenth century, a search for the "principle of vegetation" was begun by Von Helmont. His work is regarded as the classic of its time. In speaking of his experiment, Von Helmont says : "I took an earthen vessel in which I put two hundred pounds of soil,

*Russell's Soil Conditions and Plant Growth. 
dried in an oven, then I moistened with rain water and pressed hard into it a shoot of willow weighing five pounds. After exactly five years, the tree that had grown up weighed 169 pounds and about three ounces. But the vessel had never received anything but rain water or distilled water to moisten the soil, when this was necessary, and it remained full of soil which was still tightly packed, and lest any dust from outside should get into the soil, it was covered with a sheet of iron coated with tin, but perforated with many holes. I did not take the weight of the leaves that fell in the autumn. In the end I dried the soil once more and got the same two hundred pounds that I started with, less about two ounces. Therefore, the 164 pounds of wood, bark and root, arose from the water alone." A notable contribution, but only a part of the truth was found.

Glauber believed that "saltpeter" contained these important "principles." Kulbel was convinced of their presence in "humus." Along about the middle of the sixteenth century, Tull wrote interestingly of how plants feed. "It is agreed," he wrote, "that all the following materials contribute in some manner to the increase of plants, but it is disputed which of them is that very increase of food: (1) Niter, (2) Water, (3) Air, (4) Fire, (5) Earth." "Altho niter, water, air, and fire and heat aid plants in growing, the earth is the real food and increase of plants; niter and other salts prepare the earth by dividing its particles, as a knife is to cut and prepare the food; water and air move it, and by carrying and fermenting it in the juices of the plant to produce heat. Too much niter corrodes a plant, too much water drowns it, too much air dries the roots, too much heat burns it; but too much earth a plant can never have, unless it be therein wholly covered up.". 'Tull's work closes the period known as the epoch of a search for the "principle of vegetation."

\section{Early Efforts to Ascertain "Plant Nutrients"}

According to Russel, the year 1750 marks the beginning of the epoch regarded as a search for "plant nutrients." It was about 1755 when Home was set to work by the Edinburg Society "to try how far chemistry will go in settling the principles of agriculture." Home seemed to think that the whole art of agriculture centered in the "nourishing of plants." His chief contribution to plant culture was the emphasis he placed on a study of the function of "plant nutrients."

Priestley, in 1771, pointed to the fact "that plants instead of affecting the air in the same manner as animal respiration, reverse the effects of breathing and tend to keep the atmosphere pure and whole- 
some, when it is become noxious in consequence of animals either living, or breathing, or dying, and putrefying in it." Upon the observations just cited, coupled with Priestley's discovery of oxygen, is based one of the most important principles of plant physiology.

Up to about 1800 , studies were largely of a qualitative nature, but the work of DeSaussure on quantitative gaseous exchange in plants laid the foundation for work now included in the modern period of plant investigations. DeSaussure, however, viewed his studies largely from the chemical aspect.

Early in the eighteenth century, Liebig referred to the work up to his time as being of a nature "fitted only to awake pity." Liebig announced that "the crops on a field diminish or increase in exact proportion to the diminution or increase of the substances conveyed to it in manure." The fundamental truths that he contributed marked the beginning of a new era and he prepared the world for the splendid progress that followed.

About the time Liebig was startling the world with his theories, was born Von Sachs, who was later to be known as favorably in the field of botany as was Liebig in the science of chemistry. In April, 1859, Sachs was called by Professor Stöckhardt to the Experiment Station at Tharand to perfect and extend his researches on the water (nutrient solution) method, and to direct the work of the Experiment Station along lines of experimental plant physiology. Later at the Agricultural Academy at Bonn, Poppelsdorf, he gave us the now classic contributions on germination, material transportation, and translocation; and thus laid broad and deep the foundations for an experimental study of plant nutrition. His chief interest in botany seemed to be in its application to agriculture. It is to be regretted that botany and agriculture alike failed to follow his leadership in the application of plant physiology to agriculture. The intimate and definite relation between the two fields so well recognized by Stöckhardt and so masterfully developed by Sachs was all but broken with the latter's passing. A field so auspiciously developed has been allowed to lie fallow for more than half a century.

\section{The Need For Botany in a Study of Crop Problems}

Just why botanists of the immediate past have overlooked such an opportunity for service is not clear. "What is the matter with botany?" is a favorite question nowadays. Piper suggests that "intellectual isolation" is one cause of this indifference. Probably "provincialism" is at the foundation of certain troubles. One writer be- 
lieves that a "feeling of superiority" is a contributing factor to such a certain lack of interest in crops problems on the part of some botanists. Perhaps it is not impertinent to ask the question, "What is the matter with agronomists specializing in crop production?" If the botanists are somewhat at fault, so are the agronomists. Good botanical training has been available to them, but few have sought such equipment as botany can give. It must be admitted that both groups are at fault, and as a result, fundamental investigations in crops are few and are progressing slowly. We are almost at a standstill. We seem to be yet in the variety testing stage-in the "cut and try" epoch.

The contributions of chemistry have been so numerous and important that this has been referred to as the chemical age. The applications furnished agriculture are fundamentally important and are recognized as such, but we believe chemistry cannot solve our crop production problems unaided. It appears now that a newer plant physiology, quantitative in nature, is destined to enter the field of action along with chemistry, and from this combination much is to be expected.

In Illinois live two corn breeders of national reputation. I might, without the feeling of contradiction, say international reputation. Only a fortnight ago, the older of them was heard to say, "I have studied corn breeding for thirty years and I am only in the A-B-C class." The other has remarked that "after nine years of patient endeavor, I have little to say because my results seem to be so difficult of interpretation." These statements lead us to the firm belief that the trouble lies in the fact that our botanical truths are not sufficient to furnish a foundation on which to build breeding operations.

If agronomy is to occupy the important station is should, it must ally itself to the science that is basic in the interpretation of plant function; namely, plant physiology. By establishing the closest relationship among the intricate and basic problems concerning the influence of the agricultural environment on plant functions, and through these on crop production, much will be accomplished.

\section{What Are Some of the Basic Problems of Crop Production?}

So far as crop production is concerned, what are some of its basic problems? What contributions can plant physiology make?

Before attempting to answer these questions, it will be well to study briefly the general agricultural features of our state. From north to south, the length of the state is 385 miles, which means, of 
course, great variation in the climate of the respective sections. Northern Illinois receives an annual rainfall of less than thirty-five inches, while the southern third of the state receives from forty to fifty inches. Temperature variations for these areas are even more striking than rainfall differences, and result in a marked change in the length of the crop-growing seasons. At Fairfield corn may be planted during the last days of April, while at DeKalb, May 18 is the earliest date at which it can safely be planted.

The soil survey, which is more than three-fourths completed, shows how great a variation we have in our soil types. To date, about one hundred and twenty-three types have been recorded. Such extremes of soil type indicate clearly the complex nature of the cropproduction problem with which we have to deal. With such great variation in soil type and climate as we have in Illinois, is it any wonder that a man who is a successful farmer in southern Illinois might be a failure in northern Illinois?

A satisfactory solution of crop-production studies in Illinois must be founded on a full knowledge of the soil and what is taking place in it, as well as a complete understanding of the influence of climate and the inter-relationship of these great factors as they affect plant growth. Much has been done looking toward a proper solution of the soil problem, tho many vital questions remain unsolved. It will be some time before plant studies have overtaken soil investigations, because the former field remains largely untouched.

Again, what are the outstanding problems which should be attacked first? It seems to me that the fundamental crop problem is "adaptation." If this is granted, what is the method of attack? We believe the approach must be made through a study of plant physiology. "The aim of plant physiology" as stated by the great botanist Palladin, "is to gain a complete and thoro knowledge of all the phenomena occurring in plants, to analyze the complex life processes so as to interpret them in terms of simple ones and to reduce them finally to principles of physics and chemistry."

Little is now known of the sensitive or critical period in crop plants in relation to environmental factors such as moisture, temperature, and light, as viewed from the physiological aspect, more particularly in its application to field conditions. The basis of attack, then, must be the study of the relationship of environmental factors to the various life stages of crop plants. phases may be grouped as follows:

These life stages or physiologic (1) the seed stage; (2) the germ- 
inative stage; (3) the plantlet stage; (4) the active growth or vegetative stage; (5) the reproductive stage.

A thoro knowledge of the physiological behavior of farm crops must include a knowledge of the life stages, each in relation to the several factors of environment. When we have such information it is not difficult to determine the critical phase or period. We are convinced that a clear understanding of the critical period is necessary before we can proceed far in crop-adaptation studies.

A few typical questions will add emphasis to the suggestion made above. These questions are not made-up questions; they actually have been asked by Illinois farmers during the last twelve months:

1. One variety of wheat, corn or oats is better than another, Why?

2. If this variety lodges worse than another, Why?

3. If early seeding of spring wheat is best, Why?

4. This year we have scab, next year none, Why?

5. Wheat winterkills, Why?

6. Soft wheat for southern Illinois, Why?

7. Bearded wheat for northern Illinois and smooth for southern, Why?

8. Today I plant corn, tomorrow I plant from the same bag, and from today's planting I get a stand, from tomorrow's planting a poor stand of puny corn, Why?

Truly a new day is dawning in Illinois agriculture. The man on the land is once again facing the east, with always in the forefront the eternal question, $W h y$ ? It seems clear that the agronomist has come to realize his position and he now resolutely acknowledges the basic question, Why?

\section{What Is Being Done Toward Solving These Problems?}

If there is a new day in plant agriculture in Illinois, the question arises in your mind, what is being done looking to the solution of these important questions, and we feel that it is only fair that some notion be given as to what progress is being made.

Last September, Dr. Charles F. Hottes, who is recognized as a master in his field, consented to become consulting physiologist to the Department of Agronomy. In his laboratory, without doubt one of the best in the country, tho needing much additional equipment, the investigations of several basic problems are under way; and it should be added that these same problems are being studied simultaneously on the crop experiment fields. 
Illinois is one of the two leading corn-producing states of the world, with an annual total yield of more than $355,000,000$ bushels. Since corn is our great staple, it is natural that our most extensive studies should center in its physiological behavior. Strange as it may seem, there has been little investigational work on corn to determine the normal requirements of the crop. It is doubtful if we can find data which show the best temperature for the germination test of corn. Seed corn should always be germinated before being planted in the field. What is the most desirable temperature for this operation? Should the temperature be $75^{\circ}$ or $85^{\circ}$, and what influence will the temperature relationships have on the accuracy of the results? Certain we are of the fact that very little is known of the temperature requirements of the plant in its several life stages. Through the whole literature on corn, you may search for this kind of information, with little or no success.

Just as the physician understands the human body, so must the agronomist understand the plant body. If we are to understand the abnormal, or the plant in sickness, so must we understand the healthy or normal, because it is on the normal behavior that our recommendations for management are based.

Much has been written about the selection and storage of seed corn, but we find nowhere in literature data on which to make a safe recommendation. At what temperature should seed corn be stored for the maintenance of maximum germination and vigor? When seed corn is brought in from the field, how rapidly should it be dried and at what temperature? What temperature and moisture content should be maintained throughout the winter months? A line of work now under way shows clearly that there is danger of reducing too much the moisture content of seed corn. Corn dried to six per cent moisture previous to storage was slower in absorbing water and more tardy in germination than similar corn stored when it contained twice the quantity of water. The total percentage germination was lower and the vigor of the young plants was slightly less in the lowmoisture corn. On the other hand, another lot of the same corn which contained nineteen per cent water when it was stored did not do so well as the dry corn, even tho the processes of germination were more rapid. This indicates that the proper quantity of moisture for retaining vigor of seed corn in storage is nearer twelve per cent than either six or nineteen. In other words, the best quantity of water in corn to permit the proper amount of physiological activity in the seed to insure the nourishment of the young plantlet and keep it at its best, is about twelve per cent. 
What is the best moisture content for corn at planting? More than a year ago, Mr. Frank I. Mann raised the last question and suggested its importance. No doubt his experience has taught him that corn plants which begin their growth under most favorable conditions are ordinarily superior to those from the same kind of seed, but germinating and making their initial growth under less favorable conditions. Preliminary studies indicate that soaking seed corn in water previous to planting is a method of hastening germination, thereby giving the plant an earlier start than otherwise would be the case. This preliminary soaking has resulted in an increase in the yield where the crop was planted late. However, the length of time the kernels are soaked determine whether the result will be an increase or a decrease in production. Soaking for periods less than twenty-four hours is favorable to growth, whereas, soaking for a longer time either is not beneficial or is detrimental. In addition to duration of soaking, there are some indications that the benefit to be derived from this practise is vitally dependent upon the time of planting and the moisture of the soil when the planting is done. These are typical of the problems now in progress dealing with the seed stage of the corn plant.

A sister institution states that corn for seed may be gathered in the milk. Seed thus selected will germinate, but it is an easy prey for fungi, and in most instances the plants would never appear above ground. It has been clearly demonstrated that thoroly mature corn is best for seed, because fully matured seed possesses powers of resistance. Disease organisms may be present but they are unable to get a hold on the strong, healthy grain, while the early selected seed would be converted to a mouldy mass by the end of the third day after being put in the germination test.

In field practise, what should be the temperature and moisture content of the soil to give the little corn plant a rapid start? The problems with the plantlet are of the same sort as those having to do with the germination stage. An important study has just been concluded by the Agronomy Department, and the material prepared for publication, on the relation of early vigor of the corn plant to yield. This problem concerns itself with the plantlet stage primarily.

The Station has data covering twelve years of work on the frequency of the cultivation of corn. It is impossible to interpret these figures because we know so little regarding the nutrition cycle of corn. If cultivation assists in nitrate production, is the cultivation performed at such a time and under such conditions as will render these nitrates available at the time needed by the growing plant? The growing plant undergoes rapid changes in its nutrient requirements and reacts 
in its several growth phases in widely different manners. The nutrient element required today may not be liberated until tomorrow; and the stimulations making for increased growth and reproduction one day, may under apparently the same conditions lead to decreased production. Investigations on the rots of corn which are being conducted in this state are attracting the attention of corn growers everywhere. Two examples from this work will give additional proof as to how plant physiology lies at the very foundation of such studies.

Researches conducted by James G. Dickson, at the University of Wisconsin, point to a relatively high optimum temperature for the growth and sporulation of wheat scab and corn rot organisms, Gibberella sauoinetii. When this fungus is inoculated on to corn and wheat seedlings, the maximum development occurs at widely different temperatures. On wheat growing under greenhouse conditions, the fungus behaves as we would normally expect it to; its growth is most rapid and the greatest injury is caused to the host when the temperature is high. When grown on corn, practically the reverse is true. The greatest growth of fungus and the least growth of the young corn plants takes place under relatively low temperature environment. This would suggest the desirability of planting corn late in the season when the temperature is high. However, some Illinois experiments with diseased corn show that when corn planting is delayed the severity of the disease is increased, the yield reduced, and the quality of grain lowered. Thus it is manifest that two organisms that have similar optimum temperature requirements when grown alone, may have widely different requirements for their best growth when one is allowed to parasitize the other. Also when any one of the controlled standard conditions is changed, the relationship of the host and parasite is affected. In other words, there seems to exist in nature a state of equilibrium between plants and the various factors which make up their environment. When any one or more of these are altered, the others are affected and the equilibrium is changed accordingly.

Further, our corn-rot investigations bring sharply to mind the problem of disease resistance and immunity. One instance will suffice to bring this point clearly before us. We have two lots of corn, one lot very much like the other, and when planted on clean land the yields are about the same, but when planted on infested land the yield of one was reduced about fifty-two per cent and the other only about two per cent. Why this great difference? We naturally ask ourselves, What is disease resistance and what is immunity to disease?

Such problems are typical of studies in the physiological behavior of different kinds of strains or varieties of corn, and upon such studies 
must be based sound field practises. Answers to such questions will give us the key to the crop-adaptation puzzle.

Wheat is our most important small grain; therefore it is fitting that some time be given to the underlying principles of its management. Turkey Red is the most widely grown of winter wheats. It is a leading wheat for Central Illinois. Our winters are rarely ever severe enough to injure the crop. Red Rock, a much heralded wheat from Michigan, winter-kills about one-half the time. Why this difference in adaptation to climate? At this date, an effort is being made to determine the best moisture and temperature relationship at time of germination, since this is believed to be of large significance in determining how varieties differ.

The Station has five years of work on the time of seeding spring wheat. The yield from the early March seeding is about twenty bushels, the April seeding is twenty-two bushels per acre. Is it because these spring wheats develop greater vigor by being seeded early, thus at low temperature? Or is it that the crop seeded early develops its flowers early, thereby avoiding the influence of the hot weather of late June or early July? We believe it is the former, and not the latter, as we used to believe. Marquis Spring Wheat is a most satisfactory wheat for DeKalb, 125 miles north of here. Illinois No. I leads Marquis at Urbana by six bushels per acre. It has been found that Marquis germinates at a lower temperature than Illinois No. I. Here is a suggestion that one fundamental difference is in the temperature best for germination, a fact which suggests why Marquis is best for northern Illinois and Illinois No. I is best for central Illinois.

All of these problems aim at an understanding of the normal life cycle of the crops studied, an understanding of which is necessary before an accurate determination of the adaptability of any crop can be made.

I feel confident that the outline presented above points to an affirmative answer to President Kinley's question, "Is there any system which might be adopted whereby the adaptation of different crops to different soils may be more accurately determined, and the use of proper crops on soils be insured ?" I believe this plan will give to this great agricultural state a system of crop production that shall reflect credit upon the institution initiating it, and will add increased wealth and prosperity to the people of Illinois. 


\section{ECONOMIC PHASES OF · FARMING}

W. F. Handschin, Professor of Farm Organization and Management

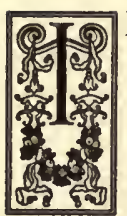

N DISCUSSING the economic phases of farming; the question of prices received for farm products and prices which must be paid by the farmer for the goods and services which he wishes to buy is of primary importance. It is important to pay somewhat special attention to the question of prices at this time because of the fact that all of our price relationships have been entirely upset during the past five or six years. Unless we analyze the situation with some care we are likely to mistake an emergency, even tho a somewhat prolonged emergency, for the usual state of affairs.

\section{Readjustment of Prices}

The farmer is suffering just now, more than from any other cause, from a maladjustment of prices between his products and the products of other industries. To be sure, other factors have contributed to his difficulty, but the wide disparity between the price of farm products and the price of the goods and services which the farmer usually buys, constitutes in my judgment the principal cause of the farmer's present difficult situation.

While farming has been practically the only important industry which has maintained normal production during the year 1921, the price of farm products has fallen, without a corresponding reduction of prices in other industries, to a point which leaves the farmer with scarcely more than seventy per cent of his pre-war purchasing power. This in turn has reacted on business in general through a reduction in the demand for the products of city industries, and has been one of the chief factors contributing to the widespread unemployment and general business depression which has obtained during the past twelve months.

As a result of this maladjustment of prices between farming and other industries, we find ourselves in the anomalous position in which the manufacturer and merchandiser have been able to maintain satisfactory prices; and at the same time "business is rotten," profits are practically unknown, and prosperity is still just around the corner. The laboring man is still enjoying a good wage scale, in the main, but a third of his fellows are out of employment, many more are working 
on reduced schedules; and the total wage fund perhaps is reduced fully as much as is the farmer's income.

I cannot, in this brief paper, take the time to enter upon a discussion of what seem to be the chief causes of this contradictory state of affairs in our industrial life. It is significant, however, to note that practically all classes of men seem now to agree that before we can have anything like a return to normal business conditions, prices of all important commodities must at least approximate a common level.

Whether this leveling of prices is to be brought about by raising the price of farm products, copper, rubber, sugar and other essential commodities which are substantially below the level of general prices; or whether it is to be brought about by scaling down the price of other products to the price level of the products mentioned, depends largely upon whose opinion is sought. The farmer wants higher prices and, for once, nearly everyone seems to be agreed that he should have what he wants. All seem to be in favor of the plan. Except for the fact that it does not work it seems to be entirely satisfactory.

The farmer would no doubt, as a matter of first choice, have his prices boosted to the level of industrial prices and wages. If he cannot have this, he wants lower prices for the things which he desires to buy. In this, however, he seems as yet to have enlisted only partial cooperation from manufacturers, merchandisers and wage earners. Meanwhile he sits tight, reduces his expenditures to the minimum, in the main because he has little to spend after paying interest, rent, taxes, wages and meeting other necessary expenses. He waits, because he must, for the steady but unrelenting economic pressure in the situation to teach other industries that only normal production of goods made on wages and sold at prices that will move them into consumption can bring general prosperity, and that much-to-be-desired state which President Harding calls normalcy.

If we agree that prices must reach a common level before we can have general prosperity,-a doctrine which seems now to be somewhat generally accepted,-it is highly important that we try to estimate as accurately as possible whether farm prices will go up, whether other prices will come down, or whether these two sets of prices will meet at some point between their present levels.

In attempting to predict what will probably happen to prices, I can take the time to set down only a few of what seem to be the more important facts bearing on the problem. We know, for example, that the production of the cereal grains in the United States has been considerably above normal during the past three years. Three suc- 
cessive favorable seasons and high yields have given us the largest production of corn during 1919,1920, and 1921 of any three-year period in our history. The present corn surplus is the largest on record. Since corn is the basis of our meat making industry we can scarcely expect any great increase in live-stock prices in the near future, altho we may logically expect the price of corn to approximate the level of live-stock prices before many months have passed. While the price of wheat is considerably below the level of general commodity prices, it is substantially above the pre-war figure and somewhat above the level of general farm prices. This is no doubt due to the very considerable exports of wheat made during 1921.

We know also that as long as we do not have general prosperity, the consumption of farm products in the United States must of necessity be below normal. Europe is now, and must remain for a long time, on a subnormal basis of consumption with reference to farm products. In view of these facts, he is an optimist indeed who can see any great prospect for a recovery in the price of farm products within the next twelve months.

If prices must reach a common level, and the prices of farm products offer no prospect of substantial early recovery, it does not require more than one shrewd guess as to what must happen to prices. One and only one conclusion remains; the price of goods made by the city industries must come down. It is only a question of how long we wish to defer the return to a reasonable measure of prosperity. This conclusion in fact offers the first, and in my judgment, the most important measure of early relief to the farmer in his present difficult situation.

This price problem, which just now confronts the farmer in somewhat acute form, is a good example of the kind of question in which the farmer must be continually exercising his individual business judgment. Obviously, he cannot himself assemble the information necessary to making such judgments intelligently. He must depend upon federal, state, or private institutions to supply him with basic information in this field. The price studies made during the past two or three years by the U. S. Bureau of Labor, by the College of Agriculture of Cornell University, and by other agencies, public and private, are good examples of the kind of service which the Agricultural College and Experiment Station should render in increasing measure in the future. Without such information, both the individual farmer and his organization will be working largely in the dark in attempting to solve many of their economic conditions. 


\section{Collective Marketing of Farm Products}

The farmer has long felt that he should have better facilities for marketing his crops and animals. Because of the violent decline in the price of farm products experienced during the past year he seems to have become more fully convinced that our present system of marketing is hopelessly inadequate. At the present time one or more farmers' organizations are developing plans for the collective marketing of nearly every one of our staple farm crops in one or more important producing areas. All of this is being done in large measure without the basic information necessary to the development of plans which shall conform in their essentials to good economic procedure and sound business practise. Without such information, we must learn largely by our own experience, which is usually both expensive and hazardous, instead of being able to profit by the experience of other undertakings subject to the same economic laws and principles.

We hear much these days, for example, regarding the orderly marketing of farm crops. By this is meant, as I understand it, that the farmer shall endeavor to market his crops as they are required for consumption. Since the consumption of nearly all of our important farm crops is surprizingly uniform throughout the twelve months of the year, the farmer would have to market approximately one-twelfth of his crops each month in the year. Reduced to its simplest terms, in the abstract, this would mean that the farmer, rather than someone else, should carry his crops until the time when they are required for consumption.

In actual practise the problem must be far less simple. Someone must first determine how much of the crop there is on hand. How much of it is to be marketed. How much would probably be consumed at different prices, and what prices will have to be named to move all of the crop into consumption during the year, allowing of course for the normal carry-over. In order that one-twelfth of the crop shall move into consumption during each month of the year, it would no doubt be necessary to pool all, or practically all, of the crop to be marketed and pro-rate the monthly price to all of the consignors to the pool.

In connection with this problem I cannot help but point out the danger of carrying over large surpluses from one year to another, in the hope that subsequent reduced production will make possible the absorption of such surpluses. 'The most obvious fact should be that the very act of somewhat artificially maintaining prices by withholding a part of the crop from the market would tend to increase rather than 
to reduce production; and, one year with another, would tend to increase rather than to reduce the size of the surplus. If any proof of this thesis is required, we need only cite the experience in sugar, rubber, tobacco, copper, and several other essential products, the surplus of which has been increased in most cases to unprecedented amounts, by means of a stimulating price and a tendency to hoard the products for a still higher price. The same thing happened in the case of a variety of manufactured products as well as in the raw materials mentioned.

Until recently, it was somewhat generally supposed by those interested in the collective marketing of farm products, that the principal steps in the successful conduct of such activities were integration, standardization, warehousing, transportation, and similar processes having to do with the physical handling of the commodities. We see now that these essential steps in the processes dealing with the physical goods are in themselves relatively simple, and that the real marketing problem deals with such questions as the influence of supply and demand on price; and, no less important, the influence of price on supply and demand. We have also come to appreciate that the problem of handling the physical goods is relatively simple as compared with the problem of financing the marketing of such goods. My point is not that the farmer cannot through collective effort improve the present marketing systems, but merely that we have not made any adequate study of the economic principles underlying the process of marketing farm products. We have dealt too much in general terms such as orderly marketing, cooperative marketing, costs of distribution, reasonable price, and a variety of other terms, which we use fluently, without bringing them under careful economic analysis in order to see what they really mean when subjected to the test of practical application.

In the problem of meeting the farmers' credit needs the question is being raised whether either the Federal Reserve System, a system based on deposit banking; or the Federal Farm Loan System, a system based on long time bond investments, can offer the farmer the kind of credit facilities which his production and marketing operations require. We know that the Federal Reserve System was designed primarily to meet short-time credit needs; that is, for ninety days or less. The Federal Farm Loan System was designed to meet the needs for mortgage credit extending over periods of five to thirty-five years. As compared with these facilities, certain of the farmer's credit needs require that his loans be carried from six to twelve months, or even longer. Many believe that we need still a third or intermediate type of credit, designed to meet certain peculiar needs of the farmer 
in so far as they cannot be satisfactorily met by the two existing agencies.

These are merely illustrations of the kind of questions confronting the farmer and his organizations in their efforts to solve some of their economic problems. They indicate the need for a more thorogoing and comprehensive program of research in the field of agricultural economics. In such a program the Agricultural College and Experiment Station should have a large part.

\section{Farming a Business of Small Units}

While one of the most obvious facts about farming is that it is a business of small units, the real significance of this fact is only partially understood. Because farming is a business of small units, and because of the public importance of its efficient development as an industry, practically all modern nations have made some effort to subsidize research activities in the interest of developing the more important scientific facts underlying the business. The agricultural experiment station is the result of this development in the United States. It would be plainly impossible for the individual farmer to work out the facts and principles which have been developed by these publicly supported institutions.

It would be almost equally impossible for many individual farmers to avail themselves of the information developed by the experiment station. To insure the more complete dissemination, and introduction into actual farm practise, of this information we have established the publicly subsidized Agricultural Extension Service and the County Farm Adviser working in cooperation with the County Farm Bureau.

One of the principal reasons for the formation of cooperative and other collective farmers' organizations is the fact that the individual farmer, representing a small business unit, cannot deal on the basis of equal advantage with the larger organized groups with which he must do business at many points. In matters of legislation, ratemaking, taxation, and collective bargaining the individual farmer must be largely ineffective. Collectively he develops strength to deal on a somewhat more nearly equal basis with other organized groups.

Whether this collective organization is to be of permanent value to the farmer depends upon how he uses this newly acquired power. If he uses it in his own interest, he may benefit largely by it only in so far as his use of it does not conflict with the public interest. If he goes beyond this point, in price enforcement, legislation, rate-making, 
taxation and other lines, both he and the public are certain to suffer as a result. Here indeed lies great opportunity for fine discrimination in making all-important judgments on the part of farmers' organizations. It will require both comprehensive information and a high order of moral responsibility to make such decisions wisely.

Because farming is a business of small units, more than one-half of all the people employed in the entire industry must be possessed of a degree of management skill adequate to assuming the sole responsibility for the success of the business. This places a peculiar handicap on farming as compared with many other industries. In most of the manufacturing industries not more than one person in five or six is required to take direct responsibility for other workers or for the making of dividends. The inevitable result is that the management skill employed in farming must in general be of a lower grade than that employed in the large-scale industries.

If in the future we are to continue to have small farms, efficiently operated, we need to make every reasonable effort to maintain and improve the management skill of our farm operators. This is already being done in very large measure through our general educational program in the state colleges of agriculture and in the secondary schools. The extension agencies, developed mainly during the past ten years, have already made a splendid contribution to the improvement of management methods particularly in the technical processes relating to production. The combined influence of resident teaching in our colleges and secondary schools, and the extension work carried on with actual farmers on their own farms, should go a long way toward offsetting the handicap in management skill imposed upon the farmer.

\section{Standardized Systems of Farming}

I believe we should go even farther than this. I believe the experiment stations, through investigation of the most successful farms in the various agricultural regions and through their other lines of research, should be able in the relatively near future to make a beginning in the development of somewhat standardized systems of farming for each of the more important type-of-farming areas. I appreciate fully that such systems would have to be made flexible enough to meet the needs of individual conditions. However, where soil types are fairly uniform and the conditions of climate, topography, markets, and transportation facilities are in the main the same, there must be at any given time a best system of farming which can be 
defined within somewhat narrow limits, if we but have the basic information. I recognize also that the individual qualifications and personal preference of the farmer and his family must be considered in the problem.

If it is true, however, as all studies go to show, that any given region can never grow successfully more than three or four staple crops, it must follow that the farmer has after all little economic choice as to what he will grow. To be sure, he may vary, to some extent, the proportions of the crops grown. But unless these crops rank practically the same from the standpoint of relative profitableness, he again has little choice. In any event, he must grow a somewhat balanced acreage of the crops included in his rotation, in order to secure good distribution of labor, the control of insect and disease pests, and a fair measure of insurance against crop failure or unfavorable prices for any one crop.

In the production of animals he has a somewhat wider range of choice than is the case with crops, since animals in general enjoy a somewhat wider range of adaptation than plants. Here too, however, he must soon be limited by the relative profitableness of different animal enterprises.

Once we get the basic facts, showing just what combinations of crop and animal enterprises are best adapted to a given region, we must recognize, I believe, that any considerable deviation from this combination will of necessity prove to be a handicap in making the maximum economic return. In fact many of these systems are already in some measure developed in the various regions. We need only to find them, determine the essentials of their organization on the basis of careful accounting analysis, and combine the fundamentals of successful management practise for the region into a somewhat standardized working plan.

I realize that all of this is difficult, in the minds of many impossible. My only reason for seriously discussing it in this company is that if we are to continue to produce food for our constantly increasing population at a price which they can pay, and at which we can still make a profit on the enterprise, we must introduce into more common practise a high degree of productivity on our farms and we must secure this productivity at the smallest possible cost. The realization of this aim is of the greatest importance to the well-being of the individual farmer, as well as to society as a whole. 


\section{Land Problems}

In conclusion, I can only mention a few of the other problems, of first importance to the farmer, which the Agricultural College and Experiment Station should bring under investigation at the earliest possible date.

The whole field of farm organization and operation needs to be brought under more careful and more comprehensive investigation. Our land problems need to be more carefully studied. We need to have the facts regarding land ownership, tenancy, the best adjustments of the lease contract, and other phases of the tenure problem. We need to learn how far the farmer can afford to go in increasing the intensivity of production on our better lands before he will get decreased returns. We should have more information showing when we can afford to take up and develop our land areas not as yet included in farms or not yet improved.

The whole question of land valuation is one of our most difficult problems. In spite of the fact that questions in the valuation of any form of property can never be answered with absolute accuracy, it is nevertheless important that the people who own our farm lands learn to evalute them more accurately from the standpoint of their actual economic return. A large part of the tendency to over-value farm lands in the United States during the past has been due to faulty accounting procedure in capitalizing too large a proportion of the gross income of such lands. The American farmer, and the cornbelt farmer in particular, has tended to use his surplus in raising the price of land rather than in raising the standard of living.

These are some of the more important problems to which, in my judgment, the Agricultural College and Experiment Station should be attempting to make answer in dealing with the economic phases of farming in the next few years. 


\section{THE AGRICULTURAL EXTENSION SERVICE}

\section{L. Mosher, President National Association of Farm Advisers, Eureka}

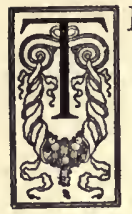

$\mathrm{HE}$ Agricultural Extension Service is the name given to that part of the program for agricultural development which connects the individual farmer and his family with the work of the state and national departments, institutions, and organizations which are working to make farming more profitable and to insure the profitable operation of our farms in the future, so that here in America the generations to come may continue to have enough food to eat, enough clothes to wear, and comfortable houses for shelter. Another function of the Extension Service is to carry to individual families on the farms information as to how the profits from farming-when there are profits-may be spent or invested so as to bring the most satisfaction to themselves, to their children, their neighbors, and the Nation.

\section{The Development of the Extension Service}

The development of the Extension Service has been a very natural one. Fifty or sixty years ago, the agricultural colleges were organized to teach the farm boys the science and the art of successful farming. The teachers soon learned that they did not have the necessary facts with which to teach; so about thirty or forty years ago the state experiment stations were organized. Gradually the people out on the farms became interested in getting more and more of the accumulated information, and fifteen or twenty years ago an extension service was instituted in order to carry such information to the farms. The leaders of the movement soon adopted the plan of placing a representative of the agricultural departments and institutions, known as a "county agent" or "farm adviser," in each agricultural county in order that he might live among the people and maintain a close personal connection between the farm family and the colleges and the departments of agriculture.

The formation of the organizations now known as county Farm Bureaus, through which the farm adviser might function and by which the payment of the expenses of maintaining the work might be insured, naturally followed the coming of the farm advisers. The federation of these county Farm Bureaus into state organizations, and of the state federations into the American Farm Bureau Federation, was a very natural development. The state and national federations 
are primarily representative and promotional organizations, through which farm people may be represented before legislative assemblies and in conferences with other organized business interests; and by which economic laws affecting the business of farming may be studied, and the development of cooperative and private enterprises which will work for the good of farm people and of all the people, may be promoted.

In this connection, after nearly ten years of service as farm adviser in two corn-belt states, during which time I have myself done some buying and selling for Farm Bureau members, it is my firm conviction that it is a mistake for the Farm Bureau as such to enter into purely merchandising enterprises, where the object is to save money rather than to do the work as a necessary part of a program planned to build up a permanent agriculture. It is a mistake also to use Farm Bureau membership fees as working capital in any buying and selling enterprise; in any purchasing done for the Farm Bureau members, the selling price should be enough above the cost to pay the overhead expense. In other words, the Farm Bureau membership fees should be used to maintain educational and promotional work for the members and not to pay the overhead of business enterprises. Neither should the time of the farm adviser be taken from what I would call the legitimate work of the Extension Service and of the Farm Bureau.

In considering the future of the Extension Service, three developing conditions may well be brought to your attention.

\section{Potential Leaders on Our Farms}

During the past quarter of a century several forces have been at work which have gradually developed a vast army of potential leaders on the farms of Illinois. Hundreds of graduates of the College of Agriculture are now on the farms. Six years ago, when Farm Bureau work was begun in Woodford county, there were only two or three men on the farms of the county who were graduates of agricultural colleges, whereas now there are ten or a dozen of them. One is president of the Farm Bureau, and one who had two years of college work is president of the county farmers' institute. A home economics graduate is president of the women's division of the farmers' institute.

The winter short courses have been the means of inspiring other hundreds of men and women to study their work and to fit themselves to take places of leadership in their communities. The Illinois 
Farmers' Institute has been a tremendous force which has inspired thousands of farm people and helped to develop in them the qualities of leadership. The president of the Illinois Agricultural Association stated publicly a few days ago that he first became interested in organized agricultural work when he was asked to assist the corn judge at a farmers' institute fifteen years ago. The Grange has helped in many localities to develop some of the strongest leaders in the county and the state, as well as in the home communities. Chautauqua speakers have led many a farmer and his good wife, and many a boy and girl, to take a new and greater interest in farm life. These, with other forces, have developed leaders in nearly every community in the state.

The development of the Farm Bureau, which, as has been pointed out, is primarily an extension organization, has been the means of bringing into activity a great number of these potential leaders. It has seemed to me during the past year that there is just now a rapid increase in the number of men and women who are taking their places as leaders in community, county, and state work. How this active and potential leadership may be utilized in the Extension Service of the near future will be considered later in connection with another condition which has gradually been developing.

\section{The Growing Appreciation of Specialists}

The same influences which have been at work developing the active and potential leadership in every community in Illinois have tended to create in the minds of the same people a respect for the work and the opinions of specialists. The college student who has come to realize, during a thoro course of study, the tremendous amount of labor and the thousands of soil tests made by Dr. Hopkins and his associates and successors, has a real regard for the statements of fact and of opinion by the soil specialists of the University of Illinois. The student of animal diseases who learns of the years of patient study and the thoro tests made by those men who discovered and developed the serum-virus preventive treatment for hog cholera will listen to or read with respect statements made by the same and other specialists regarding the control of other live-stock diseases, and he will not hesitate to follow those suggestions in his own farming operations.

The short course student who learns that the score card for corn by which he is taught to select his seed is the condensed conclusion regarding the best size and shape and condition of kernels and ears 
as determined by thousands of field trials in several corn-belt states, is not only ready to go home and select his own seed accordingly but he is also ready to accept other recommendations from recognized specialists regarding seed selection and along other lines. The farmer or his wife who, after attending a poultry culling demonstration put on by the farmers' institute or the Farm Bureau, selects his own flock of hens carefully and arranges his poultry house and provides the feed and care as suggested by the poultry specialist, to find later that his net income has been doubled and trebled, is ready to read with a responsive mind the statements of other specialists regarding other lines of work.

Looking back over fifteen years of service in state and county extension work, I have a very definite feeling that there is now a rapidly developing belief in, and a growing demand for, the advice of specialists along all lines which have to do with the science and the economics of both farming and home making.

\section{A Growing Appreciation of the Practical Knowledge Gained BY FARM EXPERIENCE}

During the recent rapid development of the Extension Service, extension workers have brought to the attention of the public so many instances of valuable practises that have been developed gradually, through the years, on individual farms and in communities, that there is now a rapidly growing realization that some of the best lessons regarding the art of agriculture are to be learned out on the farms of the country.

The announcement made this past year by the United States Department of Agriculture of the method of sanitary production of pork, known as the "McLean county system of swine sanitation," was preceded five years by the publication of the results of studies made by the Department of Farm Organization and Management of the University of Illinois, on the farms of pork producers in central Illinois. In these studies it was shown that the men who raised and fed their pigs on fresh legume pastures were able to produce pork for forty to sixty per cent less cost per pound than were those who kept their pigs in old dry-lots and small, long-used, blue-grass pastures. The difference was then attributed largely to the superior value of the green legume forage as a feed, but recent developments would indicate that much of the difference was doubtless due to the better sanitary conditions. But regardless of why those men were getting more economic returns for their capital and labor, the fact remains 
that the farm management studies showed how they were doing their work to increase their profits; and the Extension Service, farm papers and farmers' institute workers carried the story of their success to thousands of other farmers, many of whom profited by the example. About twenty years ago, out in Missouri, an unknown farmer split a log in two, made a sled of it and dragged it sideways up and down the road along his farm. His success in maintaining a serviceable road was noticed, and the King split-log drag became known throughout the country. Out of its use has been developed the patrol maintenance of dirt and gravel roads, which bids fair to revolutionize road-building methods in the corn belt.

I hope that reference to work in which I have had a part will be pardoned. I will use it here because it illustrates this point so well. In the Woodford county corn test, in which seed corn submitted by one hundred and twenty men was planted in comparative field trials for three consecutive years, those men who had followed most closely the recent teachings of the utility seed corn specialists gradually increased their corn yields until their seed was among the twenty per cent most productive. This shows the value of following the advice of specialists. It is also true, however, that the seed entered in the test by a few men who had been selecting seed for many years along lines developed by themselves, their fathers, and their grandfathers, far outclassed in yielding power that brought in by those other men. Two brothers about sixty years of age, who had learned forty years ago from their father how to select seed, and who had never attended a college, an institute, or a short course, had some of the highest yielding corn. The son of one of these men had one of the best lots of seed in the test. This test shows, therefore, that while we may well listen to the specialist, we may well watch, too, for those profitable practises which are often to be found out on the farms of men who have been doing things, intuitively perhaps, in a way that is superior to the plans suggested by the results of any scientific study which has yet been made.

\section{The Future of the Extension Service}

If these conditions, which have been pointed out as really to exist are facts, then they have a very definite bearing on the future extension policy of our state. I believe that one of the most valuable functions of the Extension Service in the future will be to develop local leaders and give them work to do. Let us encourage those who have organizing ability, and help them to organize the community 
club, the grange, the rural church, and the community school in order that they may render the great service which such community organizations elsewhere are rendering and may continue to render. Some can write. Let us help them to get together the facts being discovered by our investigators, and the records of successful practises that are being evolved on our farms, and encourage them to write articles and news notes for the local papers and the agricultural press. Some of the most effective writing being done today for the local and general press is that contributed by men and women on the farms. Some people are naturally good speakers. Let us use them. They are needed in all these local organizations, to furnish information concerning the scientific and economic principles which have to do with successful farm work and satisfying farm life, as well as to explain simple farm practises which will make farming more profitable and farm life more happy.

I believe that in the future much more of the work of the county farm adviser could well. be devoted to finding these potential leaders with their varying talents and helping them to organize for work. The collecting of facts and the putting of them into shape for these local leaders to use may well be a greater part of the farm adviser's work than it has been in the past. It may be hard for some of us who have been doing much of the organizing and writing and speaking to turn it over to others; but my best judgment tells me that he who successfully does that will multiply the effectiveness of the extension service in his county many times over.

In my judgment the growing desire for the advise of specialists will call for the employment of more of them in our State Extension Service. With a clientele of from one thousand to three thousand farmers, each of whom expects specialized service of some kind, the farm adviser is utterly unable to render the satisfactory service which was possible when he was working with three or four hundred people. This great increase in the number of interested people, and their growing belief in the specialist, make it imperative that more men and women trained along special lines be provided to go out into the counties and communities to carry to the receptive people the information which they desire.

While I believe that the scientific study of soil problems, of the principles of plant and animal breeding, of economic laws, etc., will carry us further, years hence, than any one has yet gone, experiences of the past lead me to believe that there are men on the farms all over Illinois who have gone further, intuitively perhaps, along many lines than the most thoro scientific study has yet taken us. 
While I believe that a satisfactory program for agricultural development demands increased funds and more people to be devoted to the discovery of unknown scientific truths, I believe just as fully that the most efficient extension service in the near future will be that which provides for a more systematic study of farm practises than has been undertaken in the past, in order to find those which are worth disseminating. There should be strong currents of information coming in from the farms through a branch of the Extension Service, to our institutions of learning, where they may be summarized and vital. ized and sent out again through the Extension Service to thousands of other farmers throughout the state.

In conclusion, let us picture in our minds a plan of extension service based on the developing conditions as here stated. The State Extension Service will continue to reach out over the state, through the county farm advisers, who will in the future more than in the past be county directors of agriculture, working for the interests of agriculture through the Extension Service of the University and through the Farm Bureau. The Farm Bureau will confine its activities to educational, promotional, and representative work. As county director of agriculture, the farm adviser will devote his time more fully to the development and organization of local leaders and to bringing to his people the services of specialists along all lines.

The State Extension Service will provide more and more specialists along all lines affecting farm work and farm life, and will devote considerable necessary attention to maintaining the organization necessary to successfully carry the work of the specialists out through the counties and communities to the individual farm families.

The county Farm Bureau and the county farm adviser will also be the means and the agents through which the Extension Service will operate to find and to draw in many new ideas and practises from the farms, and send them out to thousands of other people who are ready to receive and apply them. 


\title{
SOME NEXT STEPS IN THE DEVELOPMENT OF THE AGRICULTURAL COLLEGE AND EXPERIMENT STATION
}

\author{
Eugene Davenport, Dean of the College of Agriculture
}

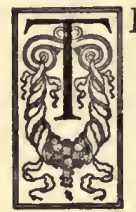

HE original purpose of the Land Grant Act and its farseeing promoters was to provide a suitable education for farmers and "mechanics," as shopmen were then called. By a "suitable education" was meant not only information and training in the subjects directly related to agriculture and the mechanic arts, but also an education in the relation of industry to other professions in life, and of artisans to the body politic, this latter idea being specifically embodied in the phrase, "without excluding other scientific and classical studies."

Instruction in the "other scientific and classical studies" proceeded successfully from the first, for neither the subject matter nor the method needed to be different from that adapted to the needs of other students. History has but one meaning to humanity, and that meaning is the same for the farmer and for the philosopher. The appeal of literature is as broad as the instincts of the race and the capacities of the individual and, outside of those who make literature a profession, it is not influenced by occupation. The facts of nature are abiding truths, and while they may be put to different uses by different people of varied occupations, yet there is a vast body of knowledge common to all peoples and fundamental to all needs.

Instruction in these fields of knowledge, therefore, encountered no special problems peculiar to their association with agriculture, but not so much could be said as to the technical subjects bearing directly upon the profession of farming. With the early attempts to teach the technical portion of an agricultural education, it became clearer with every passing year that farming had not yet risen above the status of an art and that an art which depends for its successful practise upon so many and so varied local conditions as does farming is practically unteachable in college.

\section{The Coming of the Experiment Station}

Accordingly, in the late eighties the appeal was made to Congress for a supplementary act endowing agricultural research, in order that agencies might be provided for the discovery of something really tangible, to be elaborated into teaching form. So was the Experiment 
Station established-not as an accessory but as a foundation in this newest attempt at education for the practical professions of life. So it was that research in agriculture was established in order to make successful teaching possible, its employment as a means of advancement for agriculture in general being a much later development.

The broader view of agriculture as a national industry, and the use of research for its general advancement, did not occur to the minds of even the most advanced thinkers until about the opening of the present century, when the findings of science within the field of farming began to make it clear that research could do something more than explain to students why certain practises are successful. For a score of years now it has been clear that investigation and experimentation, indeed the very broadest conception of research, is capable not only of explaining agricultural practise but also of rationalizing it and advancing it; in other words, of developing the business and the life of farming, not only from the individual, but from the community, the state, and even the national point of view.

Stated in terms of logic, this is the day of the inductive method. We are vastly concerned now about the many major premises with which we are doing business. We are not so credulous as were our ancestors. We have more tools to work with, more tests of supposed truths, and we realize more than they could realize the untoward consequences of proceeding upon false or inadequate assumptions. The fact is that we have only begun the vast undertaking of interrogating nature about this matter of agriculture, and to stop now or even slacken effort would be of all forms of folly the most foolish. "If we be wise, therefore, we shall continue to prosecute our inquiries into the mysteries of agriculture and its relations, linking close together those three manifestations of the same service-research, teaching, and extension. And in doing that we shall, without abandoning any of the old methods of inquiry, make use of certain new tools of our trade lying ready to hand but hitherto not much employed.

Chemistry has served us well; indeed until almost the present day it has been about the only science that has been particularly fruitful of results along agricultural lines. We shall continue to use it, and it is no flight of fancy to predict that what has been found by the chemist in the past is but a tithe of what awaits his achievement in the future. But we must harness other agencies-physics, for example. Undoubtedly we feed the young mainly for body building, but we feed the horse as we stoke the boiler or furnish gasoline to the motorfor the energy that may be developed. To be sure, the horse operates his own repair shop with highly skilled mechanicians, but we keep 
him and we feed him for the power he can exert, exactly as we keep and feed the engine or the motor.

There is, for want of a better term, what might be called a dynamic element in agricultural science that has been too long neglected. We recognize this quantitative element in function in the different degrees of vitality in germinating seeds; in what is called spirit or nervous energy in certain individual animals; in what Cope called growth force in individuals and in species whereby some individuals outdistance others and some species enjoy a constantly accelerated development, as in the evolution of the modern horse from a five-toed ancestor about the size of a jack rabbit. The same phenomenon is manifested also in the typical termination to growth by which an arm or a leg stops growing at the proper point while hair and skin continue to grow as long as life lasts, and regeneration of injured tissues is well-nigh universal. These are important questions not yet touched by our investigators.

When physics shall have made its contribution to agricultural research, we shall know more than we do now about the tension of films upon soil particles as affecting drainage, irrigation, and translocation, and upon the fat globules of milk in its relation to the ripening of cream and the churning of butter. We shall then be enlightened about those vast and complicated transformations of energy that accompany the tearing down of the structure of our foods and the building up of those complicated compounds on which animal and human activity depend. Then we shall no longer begin our chapters on nutrition by the absurd statement that the first object of feeding is to "keep up the body temperature," which is a resultant, not a prerequisite of physiological activity.

The biological sciences lie at the base of agricultural production, but it is not too much to say that until a very recent date their contribution has been slight outside the fields of breeding and of communicable disease.

For example, it did not help the farmer much to be told that what he has all along called wheat is really Triticum sativum. He was ready enough to believe it, but what earthly use could he make of this strictly botanical information evolved for classification purposes? It helped him but little more to be told that the berry is really a fruit, tho it was news indeed because from boyhood up he had associated fruits with things juicy and good to eat out of hand. And so it was that "glumes" and "culms" and "inflorescence" went into the intellectual scrap bag along with "plumule," "embryo," and 
"radiolaria," as interesting but not valuable agricultural information coming out of the biological era given mainly to classification.

But as botany and zoology emerged from a study of form to a consideration of structure and finally of function, then it was that the biological sciences began to vitalize agriculture almost exactly in proportion as they vitalized themselves.

And now at last we are at the threshold of a scientific study of that wilderness of function that we call physiology. It is that form of science which studies systematically what living things do as well as how they are constructed. It studies them alive and in action rather than depending, as we have too much depended, upon killing the thing in order to count its bones.

So is physiology at last coming into its own after a generation or two of practical neglect, while scientists largely have been following the lead of chemistry or have sivitched off into one of the by-roads known as evolution, plant breeding, genetics, or the study of diseases and their control. These subjects are all exceedingly useful but they are all branches of the main stem, which concerns itself with the way in which living things perform their normal functions day by day and the conditions necessary to successful growth-which, after all, is our principal agricultural problem, especially in crop production.

The successful growth of crops depends much upon new and better varieties, especially those that are resistant to disease; but it depends even more upon a better knowledge of the sensitive periods of each particular species and the attending conditions of soil and climate best suited to its production. Valuable as are the vitamines, important as is the rule of the amino acids, there is yet even greater significance in those vital activities which do not lend themselves to chemical analysis but must be studied by direct methods brought to bear upon the animal or the plant at work and discharging its normal function.

\section{The Contribution from Economics}

Slowly, haltingly, almost apologetically, has the great science of economics at last been recognized as able to contribute something to agricultural advancement.

Agriculture as a great productive industry has always figured large in the accounting of the economist. In peace it is one of the basic industries, whether considered as a source of wealth or as a reliable element in commerce and the balance of trade. In war it often turns the tide of battle, and as history abundantly demonstrates, it is the products of the land that decide the final fate of nations. 
Agriculture, therefore, has always been recognized as of high economic, social, and political consequence. But with few exceptions the economist, like the physicist, has pretty much let agriculture alone as a subject of study for its own sake. As a consequence, this great industry has not much profited by the intelligent application of wellknown economic principles, nor have farmers as a class much enjoyed the benefits of instruction in economic theory and the wellknown facts of broad human experiences in business relations.

The result has been that while here and there a few among the many students of agriculture have done the best they could in a pioneer manner, in acquiring in a kind of second-hand and rather belated fashion something of a knowledge of economics as a kind of top graft upon a technical training in agronomy, horticulture, animal husbandry, or what not; yet the world awaits a generation of men trained from the bottom up in the application of the essential principles of economics to the serious business of farming and its relation to the world of commerce and finance, in which it forms so large a part and upon which the prosperity of the farmer so largely depends. We need new agricultural specialists trained to think in terms of economics.

One of the results of these coming economic studies will be a clearer conception on the part of the public of the difference between agriculture as a great national industry and farming as an individual occupation. As a national industry, it ranks with other great producing enterprises, and the value and variety of the product is the thing in mind. As an individual occupation, it is intensely human.

From the individual point of view, agriculture is different from other producing industries in three essential respects:

First: The unit is exceedingly small and the turnover slow as compared with the managerial ability required and the capital invested.

Second: To the individual and his family, farming is a mode of life as well as a business, because the home is intimately involved with the producing plant.

Third: In general, the occupancy of the land changes about once every twenty years and much more rapidly than the ownership. That is to say, the life of the farmer is much shorter than the life of the citizen, and this involves difficult questions of ownership.

Because these things are so, an agriculture may be very prosperous to the country at large while very unprosperous, even oppressive, to a very large share of the citizens engaged in actual production. This is what has given rise to the recent demands for better credit systems, 
by which is meant systems which individual farmers can use; and it requires no prophet's vision to predict that one of the chief concerns of a thinking public in this country is to provide ways for retaining upon the land the largest possible proportion of home-owning and home-building citizens.

This is a task never yet successfully performed by any country; and it is the chief problem concerning a self-governing people, because agriculture is about the only remaining industry engaging the attention of large numbers of people in which the individual is necessarily an enterpriser and in which all the family can take part: which is only another way of saying that it is the only occupation involving large numbers, which, by its nature, breeds resourcefulness and individual independence. These matters must all enter into and characterize the coming task of the College and Station.

The greatest immediate menace to agricultural welfare and to the proper development of any state is a growing degree of irresponsible tenantry in which the owner and the tenant conspire to operate the farm for immediate results at the expense both of fertility and of typical American country life. This is the impending danger to the future of Illinois, and adequate plans for transferring ownership of farm homes from one generation to the next by a proper system of long-term credits is one of the chief problems of the commonwealth. This, too, calls for scientific investigation and treatment.

The fact must not be overlooked, at a time like this, that a great struggle is developing the world over between the country and the town. This struggle arises from the fact that while the farmer works for what the economist calls "goods,"-corn, wheat, horses, cattle, hogs, - the city works for money, the capitalist for profit, and the laborer for what he calls a living. One consequence is to unduly exalt capital in city enterprise, and another is to lead the laborer to abandon ideas of thrift and to adopt instead measures designed to secure the best living obtainable with the least exertion possible, often without regard to consequences. This false economy is pushed often to the point of systematic reduction of the results of labor in order to compel the work to provide as much employment as possible. Because of these conditions and because of a prevailing confusion as between money and goods, the whole machinery of city enterprise operates to inordinately increase the cost of standard necessary commodities, not only to the world at large but also and necessarily to the laborer himself. This is one prime cause of the gulf that is forming between the country and the town. Such a system is of course bound 
to break down some time, because the world lives upon goods and not upon money. It has already broken down in unhappy Russia, and we have before us there a concrete example of the way in which such a system will finally return its people to the land for the means of bare subsistence.

Now, to a people in this desperate condition it would be good bolshevism to nationalize the land and regard it solely as a means of producing the cheapest possible food, regardless of the home life it might and ought to support. We even had a beginning of this idea in our own country lately when a bill was proposed in Congress for taxing the land for the relief of unemployment. Any movement in this direction will not only destroy agriculture as a home-making occupation but it will remove from the people the highest incentive to labor. A man will work for nothing as he will work for a home to shelter his wife and little ones. He will work for this as he will not work even for life itself, and the home-building incentive in this country must be preserved to the utmost if we would remain a free and prosperous people. It is to matters of such far-reaching import as these that our economic studies in colleges and experiment stations must be directed, as well as to the problems of the individual farmer.

Another cause of the gulf that is forming between the country and the town lies in the field of credit, and it arises from the fact that many capitalists fail to appreciate the financial side of farming. The New York Journal of Commerce, for example, opposes all plans for long-term credit to farmers upon the ground of its undue absorption of capital. Under date of December 30, this Journal expresses itself editorially as follows:

"The credit supply of this country is not something to be distributed by 'sections' or 'interests.' . . . It is the joint possession of the community to be cautiously and soundly used for the benefit and the assistance of all and to be distributed to those who are in position not only to employ it for sound and economic purposes but to return it intact when they agree to do so. This pledge cannot be complied with by those who wish to use their borrowings for making longtime investments, or in the carrying of agricultural products on speculation."

Repeatedly since that date this journal has given voice in one form or another to the same contention, entirely ignoring the fact that upon other pages of the same issue appear advertisements for and records of transactions in municipal and industrial bonds running to periods as remote as 1998 and all possible dates between. Agri- 
culture has never asked for long-time credit beyond a period of thirty-three years, but New York City bonds are handled in the markets today as gilt-edged securities and with entire approval tho absorbing credit for more than seventy-five years ahead.

Of course the individual farmer is unable to negotiate a paper that is bankable and convertible into liquid credit. The same is true of the individual citizen of New York or any other city. But collectively both parties are able to execute securities which are easily marketable, as experience shows, to equal advantage. The bonds of the Land Bank are now selling in open market at 102, I believe, and it does not appear that either these or long-term bonds of any kind absorb capital in the sense of destroying its usefulness.

The contention of our foremost commercial journal is manifestly unsound in this matter, not only as to the facts of the case but also as to the equities; for every intelligent man who is fully informed knows that agriculture has done its full share in producing the capital of the country upon which credit rests, and every fair-minded man will agree that it is entitled in equal proportion to the enjoyment of its credit needs. From every point of view, the city man has much to do in closing up the gap between the country and the town, both in the field of production and in the handling of capital; and he cannot relegate to himself either the standards of production or the exclusive use of the capital which everybody has helped to produce.

It is contentions like those quoted from the foremost commercial journal that tend powerfully to the creation of an agricultural bloc, not only in Congress but among thinking farmers everywhere, considerable numbers of whom are coming to have not a little knowledge of the principles governing the business activities of a civilized people. For the good of all, this gulf between the country and the town must be filled up or bridged over; and the farmer, the business man, and the laborer must each do his share in so necessary a service.

From every point of view here in the exploration of a field hitherto considered as exclusively commercial, lies great work for our agricultural colleges, not only for the further enlightenment of farming but for the enlightenment of other professions as well.

\section{The OUtLook}

We are to have a new agriculture, if not indeed a new civilization, in the Middle West. In the immediate future Chicago will be an ocean port. We shall not always ship our coal and our wool and 
our cotton to the extreme northeast corner of the United States for manufacture, then ship the product back again to the center of population, which even now is just across the Indiana line. The Middle West will not always buy its steel at "Pittsburgh plus" when most of the ore comes from Minnesota and down the lakes to Gary and Joliet.

Dr. Burrill of blessed memory used to speak of Illinois as an imperial state. And such it is, for it lies at the very center of the greatest agricultural region of the earth, when land and climate and people and possibilities are all considered.

She has a people unexcelled; she has a soil capable of supporting an immense population, with coal everywhere just under the feet. A rolling surface presents no obstacles to land transportation; and with open waterways both to the Atlantic and to the western coast of South America, the advantages of these natural conditions are obvious. A boat sailing from Chicago is halfway across the Atlantic when it emerges from the mouth of the St. Lawrence. The line is almost direct from Chicago and St. Louis through the Panama Canal to the west coast of South America, a continent which lies almost entirely east of Buffalo. If the upper Mississippi valley, therefore, is at all alive to its possibilities, we shall see in the immediate future a new agriculture, if not a new civilization, centering in Illinois, which will then become not only the agricultural but also possibly the industrial and commercial center of the world. It does not require the vision of a prophet to foresee in the upper Mississippi Valley a teeming population given to manufacture and trade and supported and fed by an intelligent and a prosperous farming constituency.

The first steps have been taken in finding ways to make our agriculture permanent and also comfortable. To make it profitable we must prosecute assiduously our scientific and economic studies, in order to furnish the facts upon which our leaders must depend for successful practise. To make agriculture comfortable we must as soon as possible enter upon an era of building permanent farm homes, equipping them with modern conveniences, and surrounding them with every feasible form of outdoor beauty-real homes where typical American children can be born and nourished, drinking in with every breath the spirit of a free and a prosperous, self-governing and selfdirecting civilization.

In all this development the University can be especially helpful, particularly because of the fact that the separate units are in general too small to engage the interest of professional architects and landscape gardeners. It can do much by way of inventing and disseminating 
appropriate designs for the farmstead and its plantings and for the treatment of our rapidly improving highways, and then in arousing public interest in outdoor art. Illinois must be something besides an endless stretch of fields bare and brown for a third or a half of the year; it must develop into an harmonious landscape busy in production but restful to the eye and inspiring to the soul. Her highways must be something more than stone speedways; they can be, indeed must be, avenues of beauty connecting counties and leading to great population centers by parks of pleasantness.

Yes, we are to have a new agriculture in the Mississippi Valley. Shall it be better or worse than the one our pioneer fathers hammered out from the wilderness and slowly evolved from the prairie and the slough? That is for us to say, for what this new agriculture shall be like and what shall be the character of the civilization of which it will be a part will depend very much indeed upon the vision possessed by our farmers now and in the immediate future. It will depend also upon the degree of understanding and of cooperation which can be maintained between thinking citizens, who must take the lead, and the University, which is the public agent for investigating the knotty problems continually arising in a rapidly developing civilization.

The great question is: Shall a state like Illinois drift into its new development, accepting what the accidental fates deal out, or shall we, by taking thought, control and direct this development to some definite ends? By taking thought early and constantly, the citizens can make this development almost what they will. What we shall be later on will be the result, not of revolution, but of evolution from what we now are to what we then shall be. The future of Illinois is in her own hands and there is no limit to what may be achieved, provided only that she will support, as she has begun to support, generously the agencies for progress, and provided the University will remember, as it always has remembered, that in all real development it is the thinking citizen and not his institutions that must take the lead. 
THE PROGRAM OF THE CONFERENCE 



\section{PROGRAM}

\section{Agricultural Conference}

University of Illinois

JANUARY 26-27

1922

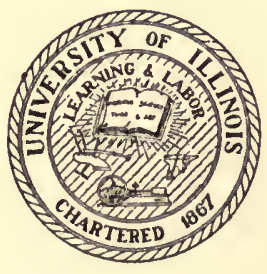

URBANA, ILLINOIS 
$\mathrm{THE}_{\mathrm{HE}}$ agriculture of the state is not standing still. Without intelligent direction, it will drift and her people become the sport of circumstance. With early foresight and reasonable attention to desirable ends, we may with confidence look forward to an agricultural development that will add enormously to the wealth of the state and to the welfare of her people.

Any program of development must be based upon an appreciation of what has been already accomplished and a vision of possibilities that lie just ahead. It is to encourage interest in such, a program that this first Agricultural Conference at the University has been called. 


\section{Thursday Morning \\ Fanuary 26 \\ $8: 30$}

\section{A QUARTER-CENTURY OF AGRICULTURAL PROGRESS IN ILLINOIS: A REVIEW OF ACCOMPLISHMENTS}

Mr. Frank I. Mann, President of the Illinois Farmers' Institute, presiding.

Greeting

Eugene Davenport, Dean of College of Agriculture

A System of Permanent Agriculture

Ralph Allen, Delavan

Developments in the Dairy Industry

N. W. Hepburn, Peoria

Developments in Horticulture

J. C. BLAIR, Professor of Horticulture

The Work of the Agricultural Experiment Station

L. H. Sмrт, Chief in Charge of Publications of the Soil Survey

The Work of the College of Agriculture

Fred H. RANkin, Superintendent Agricultural College Extension 


\title{
Thursday Afternoon
}

\section{$I: 30$}

\section{NEWER PHASES OF AGRICULTURAL PROGRESS}

\author{
Honorable B. M. Davison, Director State Department of \\ Agriculture, presiding
}

Newer Problems in Soil Treatment

FrANK I. MANN, Gilman

Business Aspects of Farming

Charles A. Ewing, Decatur

The Farm Bureau

E. T. Robbins, Farm Adviser DeWitt County

The Illinois Agricultural Association

D. O. Thомpson, Secretary, Chicago

An International Crop Reporting Service

H. J. SCONCE, U.S. Delegate to the International Institute of Agriculture at Rome, Sidell

Financing Farming

J. D. Phillips, Chairman of the Special Committee on Farm Finance, State Division American Bankers Association, Green Valley 
Thursday Evening $7: 30$

\section{AGRICULTURE IN ITS RELATION TO OTHER INTERESTS \\ Dean Eugene Davenport, presiding}

The Business of Farming in Some of Its Larger Aspects

Dr. Thomas Nixon Carver, Harvard University

The University and the Farm

Dr. David Kinley, President of the University of Illinois 


$$
\begin{gathered}
\text { Friday Morning } \\
\text { Fanuary } 27 \\
8: 30
\end{gathered}
$$

NEXT STEPS IN AGRICULTURAL DEVELOPMENT IN

ILLINOIS: A PROGRAM FOR A BETTER BAL ANCED AGRICULTURE

Mr. Charles A. Ewing, Decatur, presiding

The Introduction of New Crops

$$
\text { C. L. Meharry, Attica, Indiana }
$$

Farm Forestry in Illinois

A. N. Аввотт, Morrison

Can Illinois Come Back as a Stock Breeding Ground?

W. S. CORSA, White Hall

The Outlook for Live Stock in Illinois Agriculture

H. W. Mumford, Professor of Animal Husbandry, and Director of Live Stock Marketing, Illinois Agricultural Association

Roadside Improvement

W. N. RudD, Blue Island

The Country Home

J. V. Stevenson, Streator

Discussion 


\section{Friday Afternoon}

$I: 30$

THE PLACE OF THE AGRICULTURAL COLLEGE AND EXPERIMENT STATION IN AN ILLINOIS PROGRAM FOR AGRICULTURAL DEVELOPMENT

DR. David Kinley, President University of Illinois, presiding

Physiological Bases of Crop Production

W. L. Burlison, Professor of Crop Production

Economic Phases of Farming

W. F. Handschin, Professor of Farm Organization and Management

The Agricultural Extension Service

M. L. Mosher, President National Association of Farm Advisers, Eureka

Some Next Steps in the Work of the Agricultural College and Experiment Station

Eugene Davenport

Discussion 






